Dissertação apresentada à Escola de Engenharia de São Carlos da Universidade de São Paulo para obtenção do título de Mestre em Engenharia Mecânica.

Área de concentração: Manufatura Orientador: Prof. Tit. Eduardo Vila Gonçalves Filho

São Carlos 

FOLHA DE APROVAÇÃO 

À minha mãe. 



\section{AGRADECIMENTOS}

A Deus, pela vida, saúde, e força que me compele a seguir adiante;

À minha mãe, por todo o amor dedicado e pela minha educação;

A meu pai, que embora pouco presente, legou-me inegáveis virtudes;

À minha irmã, pela amabilidade;

À Renata, pelo amor dedicado, compreensão e apoio incondicional;

À D. Neide e ao "Seu" Crisóstomo, pelo acolhimento;

Aos meus demais familiares: avós, tios, primos e de outros graus de parentesco, por suas preces;

Ao meu orientador, Prof. Eduardo Vila, pela atenção e boa-fé ao transmitir seus preciosos conhecimentos;

Ao Prof. Arthur Porto, por ser o pilar mestre do laboratório e dos alunos que neste trabalham;

À amiga Anna Cristina, sem cujo apoio eu dificilmente teria iniciado esta empreitada;

Ao amigo Hilano, pelos diálogos sinceros e profícuos;

Ao amigo Felipe Cavani, pelas valiosas sugestões;

À amiga Beth, pela alegria e acolhimento;

Aos amigos e colegas do Laboratório de Simulação e Controle da Escola de Engenharia de São Carlos, pelo companheirismo e discussões enriquecedoras;

Aos meus amigos em Fortaleza, de cujas agradáveis companhias lastimo a falta;

À secretaria da pós-graduação, na pessoa da secretária Ana Paula, por todo o suporte.

Aos professores, funcionários e alunos da Escola de Engenharia de São Carlos da Universidade de São Paulo, por manter vivaz esta grande instituição;

À CAPES - Coordenação de Aperfeiçoamento de Pessoal de Nível Superior - pelo provimento da bolsa de estudos;

Àqueles aqui não mencionados, mas não menos importantes. 

"Não há problemas; apenas há soluções. O espírito do homem, depois, inventa o problema."

André Gide 



\section{RESUMO}

PITOMBEIRA NETO, A. R. Modelo híbrido de otimização multiobjetivo para formação de células de manufatura. 2008. 203 f. Dissertação (Mestrado) - Escola de Engenharia de São Carlos, Universidade de São Paulo, São Carlos, 2008.

O objetivo deste trabalho é propor um procedimento híbrido para a solução do problema de formação de células de manufatura com réplicas de máquinas. Constrói-se um modelo matemático de otimização multiobjetivo cujos valores das funções-objetivo são obtidos por meio da execução de um modelo de simulação de eventos discretos, o qual representa um sistema de manufatura celular. Em seguida, geram-se soluções eficientes segundo o conceito de otimalidade de Pareto através de um processo de busca por valores ótimos executado por um algoritmo genético. Três funções-objetivo conflitantes são consideradas: inventário em processo, movimentação intercelular e investimento total em máquinas. Um algoritmo de análise de agrupamento é utilizado para a redução do conjunto final de soluções. A eficácia do procedimento é avaliada mediante a aplicação a dois casos da literatura. Os resultados obtidos são analisados e comentados. Conclui-se, por fim, que o procedimento é capaz de gerar um conjunto de configurações sub-ótimas equivalentes para as células de manufatura, representando aproximadamente os trade-offs entre as três funções-objetivo.

Palavras-chave: Células de manufatura. Otimização multiobjetivo. Simulação de eventos discretos. Algoritmos genéticos. 



\begin{abstract}
PITOMBEIRA NETO, A. R. Hybrid multiobjective optimization model for manufacturing cell formation. 2008. $203 \mathrm{f}$. Thesis (Master) - Escola de Engenharia de São Carlos, Universidade de São Paulo, São Carlos, 2008.
\end{abstract}

The purpose of this work is to propose a hybrid procedure for solving the manufacturing cell formation problem. A multiobjective optimization model is built whose objective function values are realized by running a discrete-event simulation model, which represents a cellular manufacturing system. Thereafter, efficient solutions are generated following the Pareto optimality concept through a search for optimum values carried out by a genetic algorithm. Three conflicting objective functions are considered, namely, work-in-process, intercell moves and total machine investment. A clustering algorithm is applied to the final solution set so as to reduce it. The procedure efficacy is evaluated via its application to two cases from the literature. The obtained results are analyzed and commented. Finally, it is concluded that the procedure is capable of generating a set of equivalent sub-optimal manufacturing cell configurations, representing approximately the trade-offs between the objective functions adopted.

Keywords: Manufacturing cells. Multiobjective optimization. Discrete-event simulation. Genetic Algorithms. 



\section{LISTA DE FIGURAS}

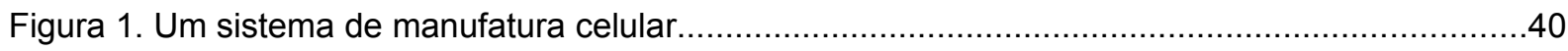

Figura 2. Um sistema de manufatura com arranjo físico funcional...................................................41

Figura 3. Células virtuais em um arranjo físico distribuído (BENJAAFAR; HERAGU; IRANI, 2002).....43

Figura 4. Células fractais (VENKATADRI; RARDIN; MONTREUIL, 1997) ........................................45

Figura 5. Dendograma representando o processo de formação hierárquica de células de produção. .56

Figura 6. O sistema 1 tem menor WIP que o sistema 2 para o mesmo nível de capacidade e utilização 63

Figura 7. Réplicas de máquinas do mesmo tipo são alocadas na mesma célula. 66

Figura 8. Réplicas de máquinas do mesmo tipo são distribuídas em células diferentes.....................67

Figura 9. A peça é alocada à célula 1 68

Figura 10. Classificação de problemas quanto à complexidade computacional (GAREY; JOHNSON, 1979) .71

Figura 11. Representação por string binária de uma solução de um problema da mochila...................74

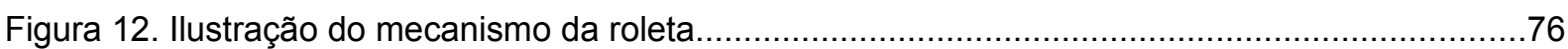

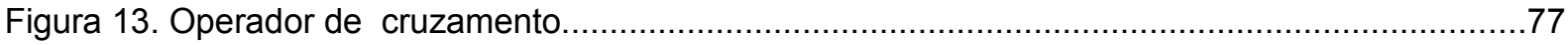

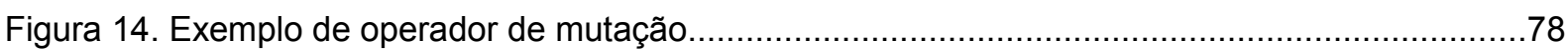

Figura 15. Mapeamento de um espaço de busca no R2 em um espaço-objetivo também no R2 ........85

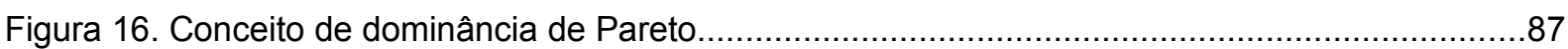

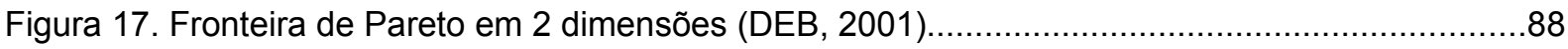

Figura 18. Vetor de objetivos ideal. No problema ilustrado, deseja-se minimizar f1 e f2 (DEB, 2001) 89

Figura 19. O método ponderado não consegue encontrar soluções em regiões não-convexas..........91

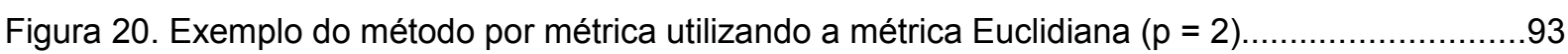

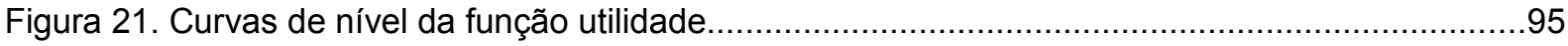

Figura 22. Esquema de funcionamento do algoritmo NSGA-II (DEB, 2001).....................................97

Figura 23. Níveis de não-dominância. Tanto f1 quanto f2 devem ser minimizadas.............................99

Figura 24. Interpretação geométrica da distância de crowding no espaço objetivo............................100

Figura 25. Procedimento geral de otimização da simulação (FU, 2002) .......................................108

Figura 26. Representação esquemática do modelo híbrido de otimização multiobjetivo proposto....111 

Figura 27. Célula de manufatura com duas réplicas da máquina tipo 2. Os lotes esperam em uma mesma fila pela liberação de umadas duas réplicas.

Figura 28. Rotas alternativas para um produto. Na rota 1 o produto é processado em 2 células, realizando 2 movimentos intercelulares, enquanto na rota 2 ele é completamente processado em apenas uma célula

Figura 29. Representação matricial de uma solução do problema

Figura 30. Atuação do operador uniforme. Os elementos em negrito foram sorteados para compor o

filho 1

Figura 31. Exemplo da aplicação do operador de mutação

Figura 32. O algoritmo genético passa ao simulador a solução candidata, o qual retorna os valores das funções-objetivo (medidas de desempenho). 132

Figura 33. Arquivo de configuração do OptSim 133

Figura 34. Tela de execução do OptSim 133

Figura 35. Solução não-dominada 1 para o problema-teste 1 146

Figura 36. Solução não-dominada 2 para o problema-teste 1 147

Figura 37. Solução não-dominada 3 para o problema-teste 1 147

Figura 38. Solução não-dominada 4 para o problema-teste 1 148

Figura 39. Solução não-dominada 5 para o problema-teste 1 148

Figura 40. Representação gráfica da solução obtida por Wu (1998). 150

Figura 41. Comparação entre a solução de Wu e solução não-dominada 5 obtida. 153

Figura 42. Solução não-dominada 1 para o problema-teste 2 165

Figura 43. Solução não-dominada 2 para o problema-teste 2 166

Figura 44. Solução não-dominada 3 para o problema-teste 2 166

Figura 45. Solução não-dominada 4 para o problema-teste 2 167

Figura 46. Solução não-dominada 5 para o problema-teste 2 167

Figura 47. Representação gráfica da solução obtida por Venugopal (1992). 168 



\section{LISTA DE GRÁFICOS}

Gráfico 1. Aumento de WIP à medida que a utilização se aproxima de $100 \%$

Gráfico 2. Evolução temporal do WIP representado como um processo estocástico de nascimento e morte. 104

Gráfico 3. Estados transiente e estacionário em um sistema de manufatura. 104

Gráfico 4. Evolução da função-objetivo "inventário em processo" ao longo das gerações. 141

Gráfico 5. Evolução da função-objetivo "investimento em máquinas" ao longo das gerações. 141

Gráfico 6. Evolução da função-objetivo "movimentação intercelular" ao longo das gerações. 142

Gráfico 7. Evolução do valor médio populacional das 3 funções-objetivo em direção a menores valores do problema 1 143

Gráfico 8. População inicial e aproximação da fronteira de Pareto no problema 1 144

Gráfico 9. As soluções do problema 1 obtidas após a clusterização por ALC estão realçadas em preto

Gráfico 10. Inventário em processo aumenta progressivamente no sistema celular proposto por Wu (1998)

Gráfico 11. Inventário em processo em um sistema de manufatura funcional equivalente ao sistema celular proposto por $\mathrm{Wu}(1998)$ 155

Gráfico 12. Evolução do inventário em processo ao longo das gerações 161

Gráfico 13. Evolução da movimentação intercelular ao longo das gerações 162

Gráfico 14. Evolução do investimento em máquinas ao longo das gerações. 162

Gráfico 15. Evolução do valor médio populacional das 3 funções-objetivo em direção a menores valores do problema 2 163

Gráfico 16. População inicial e aproximação da fronteira de Pareto no problema 2. 163

Gráfico 17. As soluções do problema 2 obtidas após a clusterização por ALC estão realçadas em preto 165 



\section{LISTA DE QUADROS}

Quadro 1. Pseudo-código da heurística ROC (SINGH; RAJAMANI, 1996).....................................50

Quadro 2. Pseudo-código do algoritmo DCA (CHU; TSAI, 1990).................................................51

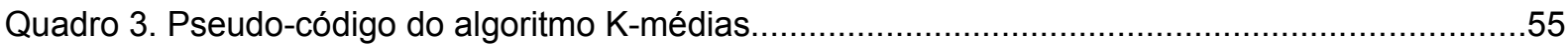

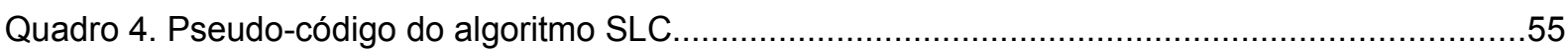

Quadro 5. Pseudo-código do algoritmo genético simples (GOLDBERG, 1989)................................73

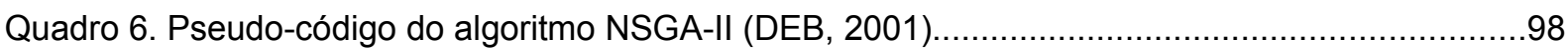

Quadro 7. Pseudo-código do modelo do híbrido de otimização multiobjetivo proposto.......................112

Quadro 8. Pseudo-código da política de roteamento de lotes adotada...........................................121

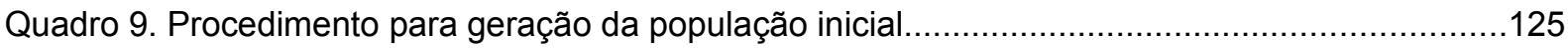

Quadro 10. Procedimento para redução da população final..........................................................130

Quadro 11. Definição em Python da classe "máquina" com o uso do módulo SimPy.......................131 



\section{LISTA DE TABELAS}

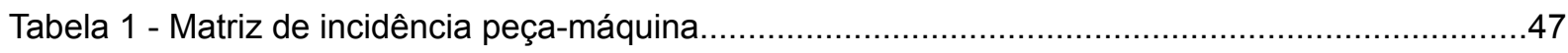

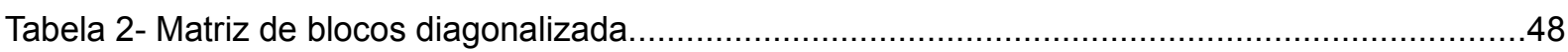

Tabela 3 - Exemplo de matriz com elementos excepcionais e vazios...........................................49

Tabela 4 - Matriz diagonal não contém informação quanto a réplicas de máquinas.............................65

Tabela 5 - Configuração do sistema de manufatura celular utilizada - Adaptado de Wu (1998)........122

Tabela 6 - Parâmetros de simulação utilizados na validação do modelo de simulação......................122

Tabela 7 - Parâmetros do problema utilizados na validação do modelo de simulação.......................123

Tabela 8 - Comparações entre resultados teóricos e simulados...................................................123

Tabela 9 - Seqüências de fabricação e demandas dos produtos.................................................138

Tabela 10 - Tempos de processamento dos produtos em cada máquina (minutos). Adaptado de Wu

Tabela 11 - Número mínimo de réplicas por tipo de máquina. 139

Tabela 12 - Parâmetros do algoritmo genético aplicado ao problema-teste 1 ..................................139

Tabela 13 - Parâmetros da simulação aplicada ao problema-teste 1 .............................................140

Tabela 14 - Parâmetros de projeto utilizados no problema-teste 1 ..................................................140

Tabela 15 - Soluções não-dominadas obtidas pela redução da fronteira de Pareto aproximada. Os campos sombreados representam o melhor valor do respectivo objetivo......................................144

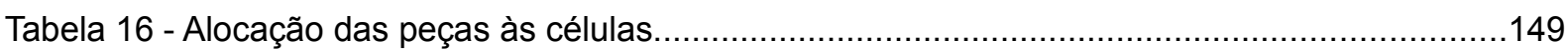

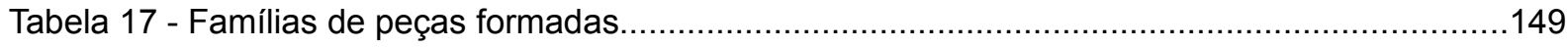

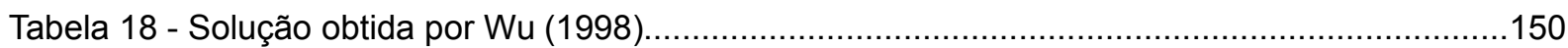

Tabela 19 - Valores adotados para os parâmetros da simulação da solução obtida por Wu (1998)...151

Tabela 20 - Resultados da simulação da solução obtida por Wu (1998). 151

Tabela 21 - Resultados da simulação da solução obtida por Wu (1998) quando adaptada a um arranjo físico funcional. 154

Tabela 22 - Seqüências de fabricação e demandas dos produtos (VENUGOPAL; NARENDRAN, 1992)

Tabela 23 - Tempos de processamento dos produtos em cada máquina (minutos). Adaptado de Venugopal e Narendran (1992). 158 

Tabela 24 - Número mínimo de réplicas por tipo de máquina para o problema abordado por

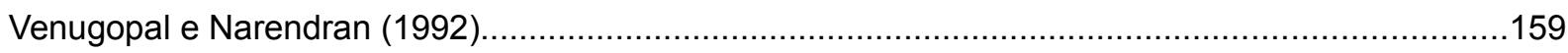

Tabela 25 - Parâmetros do algoritmo genético aplicado ao problema-teste $2 \ldots \ldots \ldots \ldots \ldots \ldots \ldots \ldots \ldots \ldots \ldots \ldots . . .159$

Tabela 26 - Parâmetros da simulação aplicada ao problema-teste 2 ............................................159

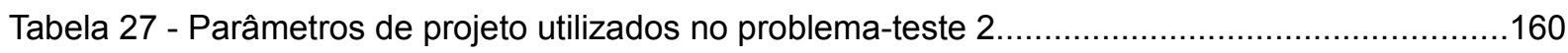

Tabela 28. Soluções não-dominadas obtidas pela redução da fronteira de Pareto aproximada. Os campos sombreados representam o melhor valor do respectivo objetivo......................................164

Tabela 29 - Solução obtida por Venugopal (1992)................................................................168

Tabela 30 - Valores adotados para os parâmetros da simulação da solução obtida por

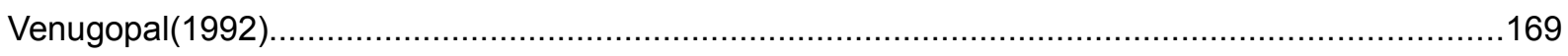

Tabela 31 - Resultados da simulação da solução obtida por Venugopal (1992)...............................169 



\section{LISTA DE ABREVIATURAS E SIGLAS}

$\mathrm{AE} \quad$ Algoritmo evolucionário

AG Algoritmo genético

ALC Average linkage clustering algorithm

CLC Complete linkage clustering algorithm

DCA Direct clustering analysis

Inv Investimento em máquina

Mov Movimentação intercelular

NSGA-II Non-dominated sorting genetic algorithm versão 2

ROC Rank order clustering

SLC Single linkage clustering algorithm

SPEA Strength Pareto evolutionary algorithm

VEGA Vector evaluated genetic algorithm

VUT Variability, utilization and time

WIP Work-in-process 



\section{LISTA DE SÍMBOLOS}

$\mathrm{a}_{\mathrm{ki}}$

$\mathrm{A}_{\mathrm{ij}}$

C

$\mathrm{Ca}_{\mathrm{a}}$

$\mathrm{C}_{\mathrm{e}}$

$\mathrm{D}_{\mathrm{j}}$

$\mathrm{E}[\mathrm{X}]$

$\mathrm{GI} / \mathrm{G} / \mathrm{m}$

L

$l_{\mathrm{p}}$

$\mathrm{p}(\mathrm{x})$

P

$\mathrm{Pt}$

$\mathrm{R}_{\mathrm{i}}$

$\mathrm{S}_{\mathrm{ij}}$

$\mathrm{T}_{\mathrm{i}}$

te

$t_{i j}$

$\mathrm{U}(\mathrm{a}, \mathrm{b})$

$\lceil\mathbf{x}\rceil$

$\mathrm{X}_{\mathrm{ij}}$
Elemento ki do vetor binário

Elemento ij da matriz de incidência peça-máquina

Número máximo de máquinas admissível por célula;

Coeficiente de variação do processo de chegada na fila

Coeficiente de variação do tempo de processamento

Demanda do produto j no período

Valor esperado de X

Sistema de filas com chegadas independentes e distribuição genérica, processamento com distribuição genérica, e m processadores

Inventário em processo

Medida de distância

Função de penalidade

Parâmetro que define a medida de distância utilizada.

População na geração t

Número de réplicas do tipo i necessárias para o atendimento da demanda total esperada

Coeficiente de similaridade

Tempo total disponível no período para o tipo de máquina i

Tempo de processamento

Tempo de processamento do produto j na máquina i

Distribuição de probabilidades uniforme discreta;

Função que retorna o menor inteiro superior a $\mathrm{x}$

Variável binária que assume valor 1 se o produto j é processado na máquina i, e 0 caso contrário 

W

$\mathrm{W}_{\mathrm{q}}$

$\mathbf{w}$

$\mathbf{X}$

$\mathbf{z}^{*}$

$\rho$

$\lambda$

$\Phi$

Tempo médio no sistema (tempo de atravessamento)

Tempo médio de espera em fila

Vetor de custos de uma unidade de cada tipo de máquina

Matriz de variáveis de decisão

Vetor de objetivos ideal

Nível de utilização dos recursos

Taxa de chegada da demanda

Domina - indica que o elemento à esquerda do símbolo domina o elemento à direita

Modelo de simulação 



\section{SUMÁRIO}

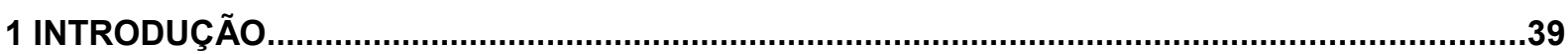

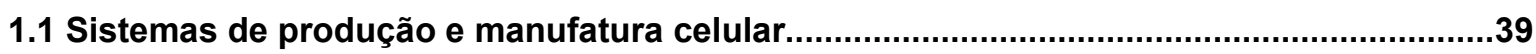

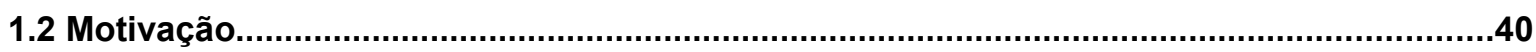

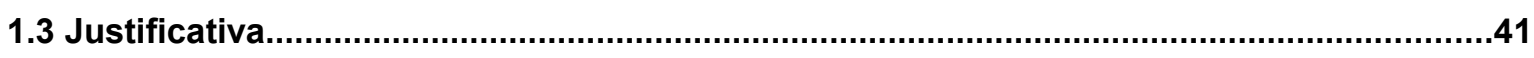

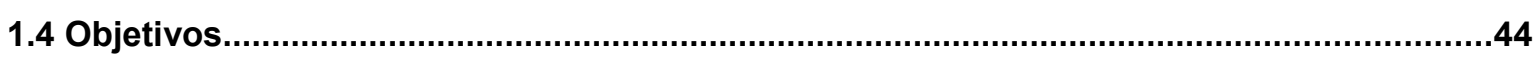

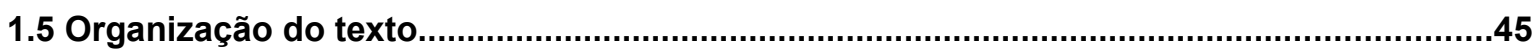

2 PROJETO DE SISTEMAS DE MANUFATURA CELULAR....................................................47

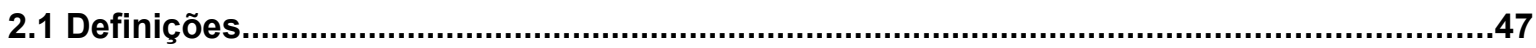

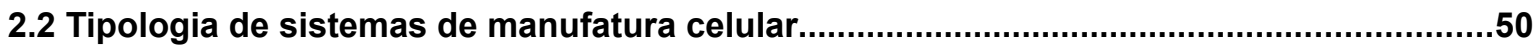

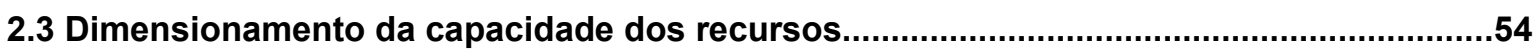

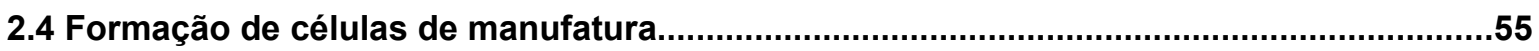

2.4.1 Manipulação direta da matriz de incidência peça-máquina..............................................57

2.4.2 Técnicas baseadas em coeficientes de similaridade e algoritmos de análise de

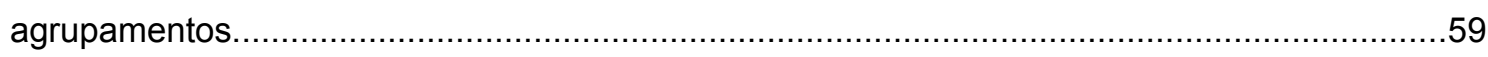

2.5 Medidas de desempenho de células de manufatura.......................................................65

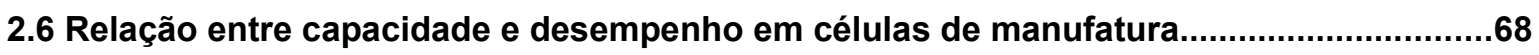

2.7 Formação de células com réplicas e múltiplos roteamentos.................................................72

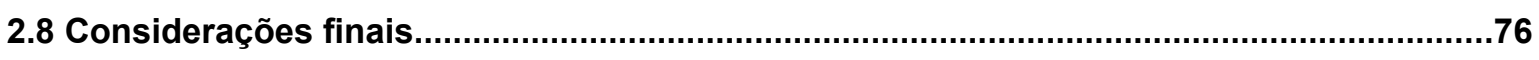

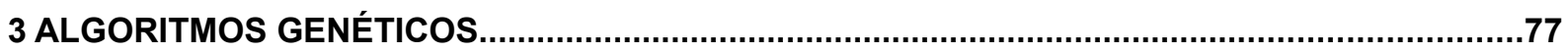

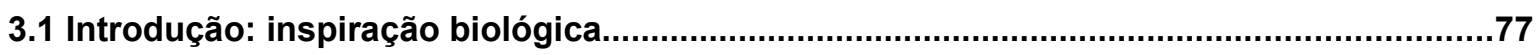

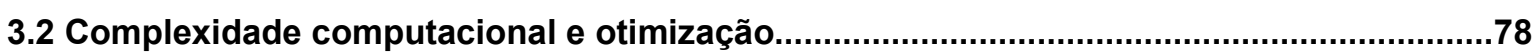

3.3 Heurísticas, meta-heurísticas e algoritmos genéticos............................................................

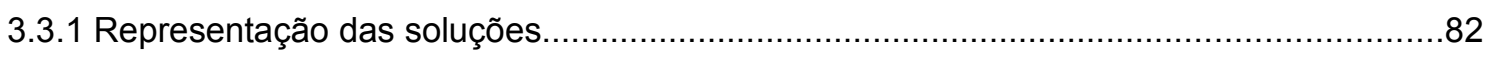

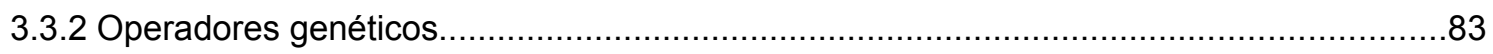

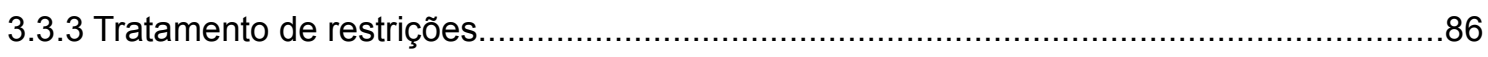

3.4 Aplicação de algoritmos genéticos ao projeto de sistemas de manufatura......................88

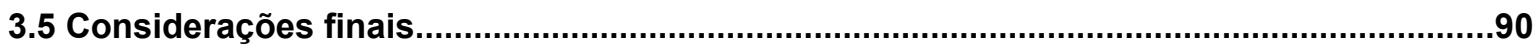

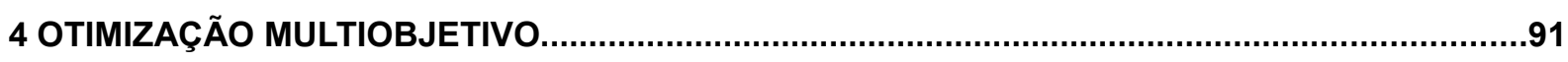

4.1 Formulação matemática de um problema multiobjetivo..................................................92

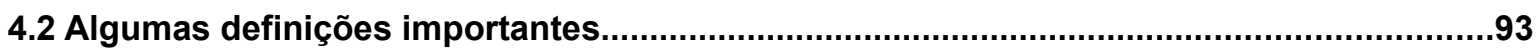

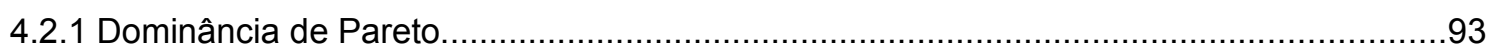

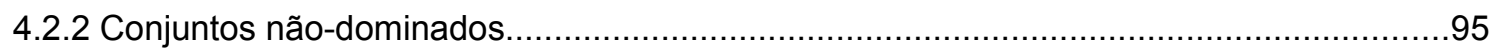

4.2.3 Conjunto ótimo de Pareto e fronteira ótima de Pareto.....................................................96

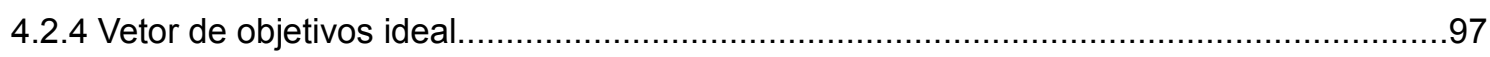

4.3 Métodos clássicos para a solução de problemas de otimização multiobjetivo...................98

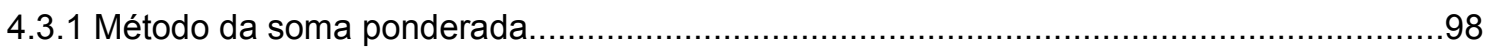

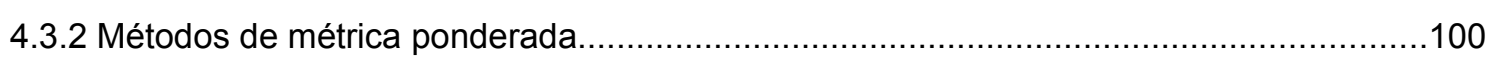

4.3.3 Métodos de função de valor (ou de utilidade).........................................................102 

4.4 Solução de problemas de otimização multiobjetivo por algoritmos evolucionários......103

4.4.1 Non-dominated Sorting Genetic Algorithm versão 2 - NSGA II....................................105

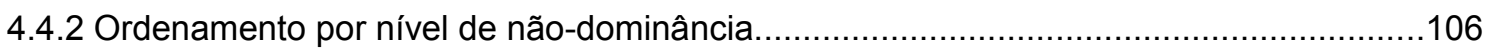

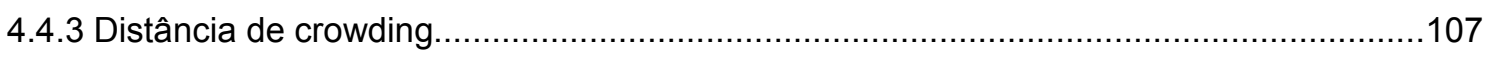

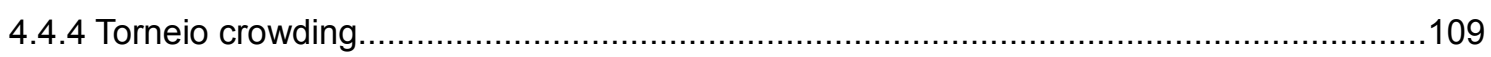

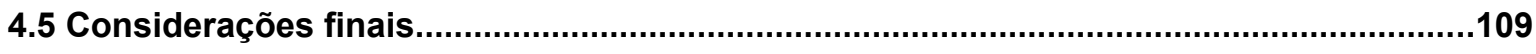

5 OTIMIZAÇÃO BASEADA EM SIMULAÇÃO.......................................................................111

5.1 Dinâmica de um sistema de manufatura como um processo estocástico........................111

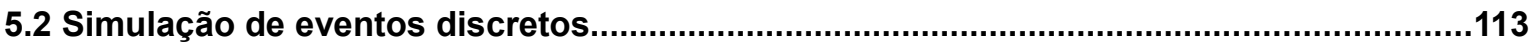

5.2.1 Verificação e validação de modelos de simulação...........................................................113

5.2.2 Uso de orientação a objetos em simulação de eventos discretos....................................113

5.3 Otimização baseada em de simulação de eventos discretos............................................114

5.4 Considerações finais.................................................................................................116

6 PROCEDIMENTO HÍBRIDO PROPOSTO PARA FORMAÇÃO DE CÉLULAS DE MANUFATURA

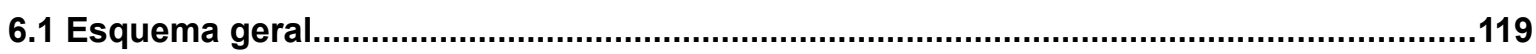

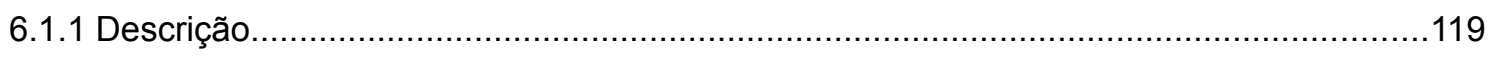

6.1.2 Características de um sistema de manufatura celular representadas no modelo de

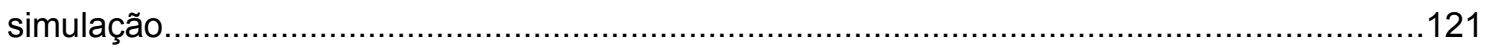

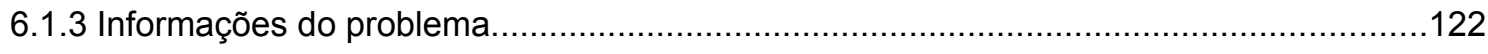

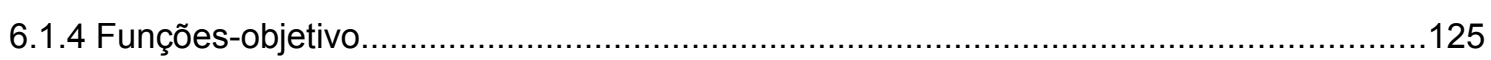

6.1.5 Formulação matemática do modelo de otimização....................................................126

6.2 Modelo de simulação de eventos discretos...............................................................128

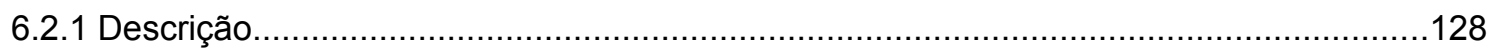

6.2.2 Verificação e validação do modelo de simulação desenvolvido....................................131

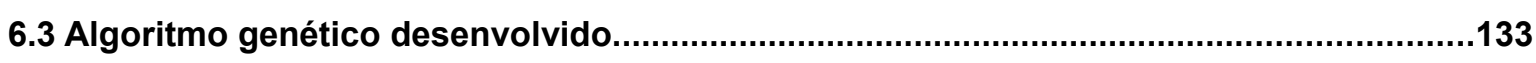

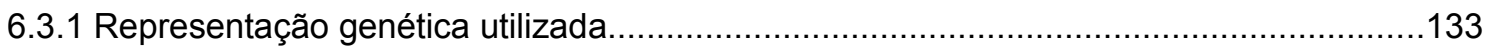

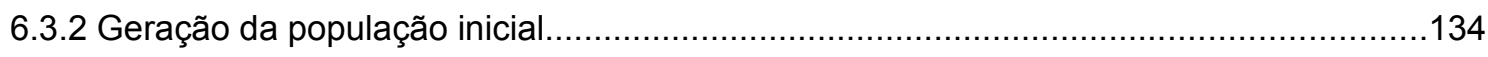

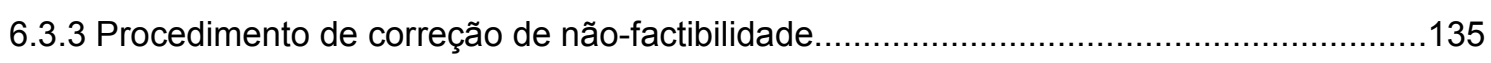

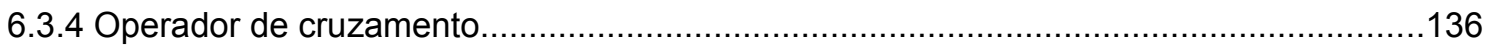

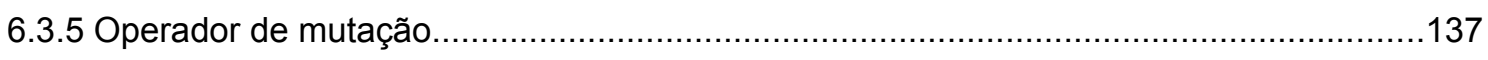

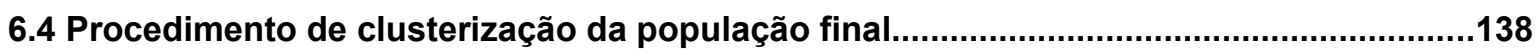

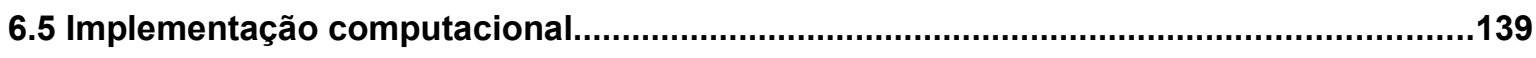

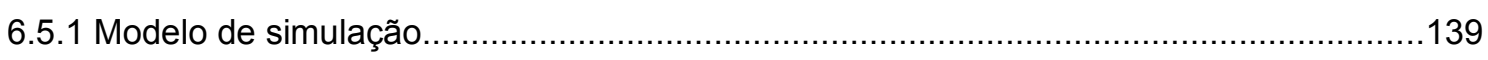

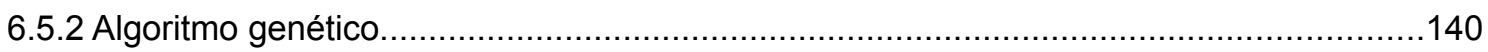

6.5.3 Integração do modelo de simulação com o algoritmo genético.....................................141

6.5.4 Procedimento de redução da população final.............................................................143

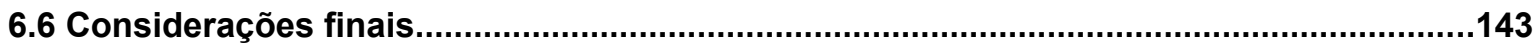

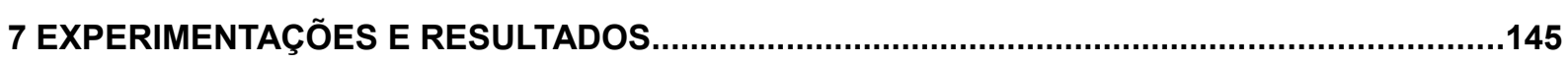

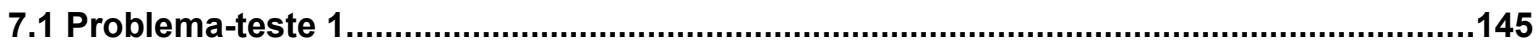



7.2 Problema-teste 2. 164

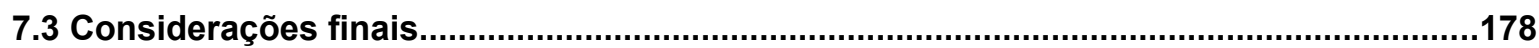

8 CONSIDERAÇÕES FINAIS E TRABALHOS FUTUROS

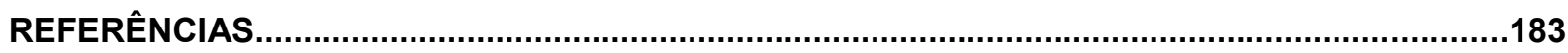

APÊNDICE A - CÓDIGO-FONTE DO MODELO DE SIMULAÇÃO EM PYTHON..........................189

APÊNDICE B - RASTREAMENTO DA EXECUÇÃO DO MODELO DE SIMULAÇÃO......................201 



\section{INTRODUÇÃO}

\subsection{Sistemas de produção e manufatura celular}

A partir dos anos 80 , com a implantação pelos japoneses de estratégias de manufatura como diferencial competitivo, indústrias em todo o mundo passaram a buscar melhorias de processo e redução de desperdícios. Essa nova visão da produção deu origem a vários movimentos inspirados em experiências bem sucedidas, tais como a manufatura Just-in-time, Qualidade Total, e mais recentemente, a Produção Enxuta.

Uma característica comum a todos esses movimentos é a importância dada à redução de desperdícios. Sob essa ótica, movimentações desnecessárias devem ser minimizadas e estoques devem ser reduzidos ao máximo, de forma a gerar menores custos de capital e melhorar o nível de serviço ao cliente por meio de tempos de entrega mais curtos.

Nesse ambiente de busca por menores custos, as células de manufatura despontaram como alternativa às formas tradicionais de organização da fábrica, significando uma configuração intermediária entre a produção em massa da linha de fabricação, e a produção em grandes lotes do arranjo físico funcional. Tal forma de estruturar a produção no chão-de-fábrica tem rendido ganhos consideráveis para empresas que produzem um volume médio, e oferecem uma variedade de produtos também média.

O projeto das células de manufatura, no entanto, está longe de ser uma tarefa fácil. Várias técnicas foram desenvolvidas, das mais intuitivas às mais avançadas. Devido à complexidade natural exibida por sistemas de produção, 
muitos ganhos podem ser obtidos pela aplicação de métodos mais precisos.

\subsection{Motivação}

Ao se projetar ou modificar o sistema de produção de uma empresa, deve-se avaliar o custo das opções disponíveis e seu impacto estratégico. No entanto, é difícil mensurar todos os fatores economicamente relevantes em termos monetários.

Mesmo assim, é possível saber que um fator é desejável, enquanto outros são indesejáveis. Por exemplo, em manufatura celular é desejável ter-se o menor fluxo intercelular possível, visto que isso propicia melhor controle da produção e menor uso de sistemas de movimentação. Não obstante, é difícil calcular em valores monetários de forma precisa o custo de movimentação de um lote entre duas células.

Quando é possível medir todos os fatores de interesse em termos monetários, pode-se criar um modelo de otimização com apenas uma funçãoobjetivo: a minimização do custo total, ou a maximização do lucro. Entretanto, quando isso não é possível, deve-se pensar em uma forma de otimizar todos os fatores de impacto simultaneamente.

Além disso, os sistemas de manufatura são muito influenciados por fenômenos de comportamento probabilístico, entre eles a demanda, a ocorrência de falhas em equipamentos e a variabilidade natural nos tempos de operação. Com base nesses fatos, este trabalho teve origem no seguinte questionamento: Como formar células de manufatura com réplicas de máquinas levando-se em consideração múltiplas medidas de desempenho, principalmente aquelas fortemente 
influenciadas por fenômenos variáveis?

\title{
1.3 Justificativa
}

\section{Uma nova abordagem para o problema}

Apesar de existirem metodologias e técnicas que auxiliam o projeto de células, ainda há muitas nuances do problema a serem exploradas, devido à sua complexidade. A incorporação de fatores que impactam no desempenho operacional da fábrica, mas que até então foram pouco considerados simultaneamente em modelos de otimização, pode promover ganhos econômicos sensíveis. Recentemente, pesquisadores começaram a propor modelos que tentam capturar um número maior de fatores importantes, como ressaltado por Jayaswal e Adil (2004, p.2420):

\begin{abstract}
A review of the literature on CF [cell formation] considering minimizing intercell moves reveals that works that consider all the important factors simultaneously - production volume, operation sequence, splitting (or allocating) replicate machines to different cells, alternative process routing and cell size - are few. Many minimize intercell moves without accounting for the trade-off with machine costs. ${ }^{1}$
\end{abstract}

\section{Abordagem multiobjetiva}

Muitos fatores presentes em sistemas de manufatura celular apresentam interações complexas e impactos no custo. A seguir são evidenciadas algumas dessas relações:

1 Uma revisão da literatura concernente à formação de células considerando a minimização da movimentação intercelular revela que são poucos os trabalhos que consideram todos os fatores importante simultaneamente, tais como: volume de produção, seqüência de operações, separação (ou alocação) de réplicas de máquinas a diferentes células, rotas de processamento alternativas e tamanho das células. Muitos trabalhos minimizam a movimentação intercelular sem considerar o trade-off com o custo das máquinas. (Tradução própria) 
- O inventário médio em processo é a quantidade média de lotes de produção que permanecem no chão-de-fábrica enquanto são fabricados. É importante minimizar essa quantidade, pois os lotes geram custos financeiros, ocupam espaço na fábrica, dificultam o planejamento e controle de produção, e mascaram ineficiências operacionais. De fato, a minimização dos estoques é um dos principais objetivos da filosofia administrativa conhecida por "Produção Enxuta";

- A movimentação intercelular é a principal função-objetivo usada na maioria dos modelos de formação de células. Como já exemplificado, sua minimização diminui o custo de movimentação e melhora o controle de produção. Tem impacto no inventário em processo, pois a mera alocação de máquinas a células de manufatura não leva em consideração os fluxos logísticos nas mesmas, podendo gerar ineficiências operacionais;

- Finalmente, a minimização do investimento total em máquinas é um objetivo econômico de impacto direto na lucratividade. Hopp e Spearman (2000) evidenciam em sua "Fisíca da Fábrica" a relação entre a capacidade do sistema de produção e o inventário em processo. Segundo os autores, quanto maior a capacidade ociosa (incorrendo-se em maior investimento), menor o inventário em processo. Hurley e Simon (1999) consideram essa capacidade ociosa como uma proteção a variações no fluxo de produção, dando o nome de "capacidade protetiva". Deve-se ressaltar também que, quanto maior o número de máquinas disponíveis, menor a movimentação intercelular, desde que haja uma alocação adequada das máquinas nas células. 
Deve-se reconhecer, assim, o caráter multiobjetivo do problema de formação de células de manufatura.

\section{O uso de algoritmos evolucionários}

Uma técnica que tem atraído a atenção dos pesquisadores nos últimos anos é o uso de algoritmos evolucionários - AEs (algoritmos genéticos, programação genética e estratégias evolutivas). AEs são algoritmos flexíveis, pois não fazem suposições sobre a estrutura do problema a ser solucionado, possibilitando sua fácil adaptação. São aplicados intensivamente à otimização objetivo em virtude de seu funcionamento intrinsecamente paralelo.

O uso de simulação de eventos discretos

A simulação de eventos discretos facilita a modelagem de fatores de complicada análise matemática, principalmente aqueles de comportamento estocástico. Desde que algumas importantes medidas de desempenho de sistemas de manufatura, tais como inventário em processo e movimentação intercelular, são sensíveis à variabilidade estatística e apresentam interdependências, a simulação torna-se uma ferramenta valiosa para a obtenção de estimativas dessas medidas. 


\subsection{Objetivos}

Objetivo geral

Propor um procedimento híbrido para a solução do problema de formação de células de manufatura com réplicas de máquinas por meio de um modelo de otimização multiobjetivo, cujos valores das funções-objetivo são obtidos com o uso da simulação de eventos discretos.

Objetivos especificos

- Formular um modelo de otimização multiobjetivo do problema de formação de células de manufatura com réplicas de máquinas considerando como funções-objetivo o inventário em processo, a movimentação intercelular e o investimento total em máquinas;

- Desenvolver um modelo de simulação de eventos discretos que represente genericamente um sistema de manufatura celular com réplicas de máquinas, o qual fornecerá medidas de desempenho (valores das funções-objetivo);

- Implementar um algoritmo genético para a realização de busca por soluções Pareto-ótimas, levando em consideração as medidas de desempenho simultaneamente;

- Integrar o modelo de simulação desenvolvido e o algoritmo genético em uma aplicação híbrida (otimização e simulação);

- Gerar soluções não-dominadas (Pareto-ótimas ou sub-ótimas) para o 
problema de formação de células de manufatura com réplicas de máquinas;

- Implementar um algoritmo de clusterização (análise de agrupamentos) para reduzir sem grandes perdas de informação o número de soluções obtidas;

- Testar a aplicação desenvolvida em dois conjuntos de dados disponíveis na literatura da área.

- Analisar os ganhos de eficiência possíveis nas medidas de inventário médio em processo, movimentação intercelular média e investimento total em máquinas;

\subsection{Organização do texto}

Esta dissertação está subdividida em: introdução (capítulo 1), referencial teórico (capítulos 2 a 5), desenvolvimento do procedimento (capítulo 6), resultados (capítulo 7) e, por fim, conclusão (capítulo 8).

O capítulo 2 discorre sobre os sistemas de manufatura celular e algumas técnicas tradicionais utilizadas para projetá-los.

O capítulo 3 descreve a estrutura geral de um algoritmo genético e sua origem, ressaltando sua utilidade para a solução de problemas de otimização difíceis.

No capítulo 4 apresenta-se a otimização multiobjetivo, ressaltando-se a dificuldade em resolver problemas com múltiplos objetivos. Descrevem-se algumas técnicas clássicas e o uso recente de algoritmos evolucionários.

No capítulo 5 comenta-se sobre a aplicação da otimização baseada em 
simulação a problemas em manufatura.

O capítulo 6 apresenta o procedimento híbrido proposto e sua implementação computacional. Descrevem-se os fatores incluídos na modelagem, detalhes do funcionamento do modelo de simulação de eventos discretos e o algoritmo genético desenvolvido.

A experimentação realizada e os resultados são incluídos no capítulo 7 . Apresentam-se dois problemas-teste da literatura e todos os dados utilizados. Exibem-se gráficos dos valores obtidos pelas soluções e representações esquemáticas das células de manufatura formadas.

Por fim, no capítulo 8 são feitas considerações quanto aos resultados e sugerem-se trabalhos futuros. 


\section{PROJETO DE SISTEMAS DE MANUFATURA CELULAR}

\subsection{Definições}

Manufatura celular refere-se à aplicação do conceito de Tecnologia de Grupo à manufatura. A Tecnologia de Grupo surgiu nos anos 60 e baseia-se no princípio da identificação de elementos semelhantes em uma fábrica. Dessa maneira, seria possível tanto a formação de famílias de produtos como a agregação de processos de fabricação (SINGH; RAJAMANI, 1996).

Existem várias definições para manufatura celular. Em seguida, são relacionadas três definições:

Por Wemmerlov e Johnson (1997, p. 29):

A manufacturing cell is a production unit for which a group of functionally dissimilar equipment are located in close proximity and dedicated to the manufacture of a family of parts and/or products with similar characteristics ${ }^{2}$

Segundo Irani (1999, p. 38), "a manufatura celular envolve o processamento de uma coleção de peças similares em um grupo dedicado de máquinas ou processos de manufatura."

Askin e Goldberg (2001) definem célula de manufatura como "uma coleção de máquinas ou processos formada para produzir uma família de produtos”.

Sistemas celulares surgiram como uma alternativa às organizações tradicionais de sistemas de produção, entre elas a linha de produção e a organização funcional. Rapidamente se adequaram a empresas que possuem volume de produção média, tipicamente por lotes, e variedade de produtos de média a alta (SLACK; CHAMBERS; JOHNSTON, 2002).

2 Uma célula de manufatura é uma unidade produtiva na qual um grupo de equipamentos funcionalmente dissimilares são posicionados em proximidade e dedicados à manufatura de uma família de peças ou produtos com características similares. (Tradução própria) 
A manufatura celular pode ser implementada física ou logicamente. No primeiro caso, as máquinas constituintes de uma célula são posicionadas umas próximas às outras, com o objetivo de reduzir a movimentação de materiais. 0 arranjo físico é disposto em células. O segundo caso envolve apenas a organização lógica do sistema, em que as máquinas não são efetivamente posicionadas no mesmo local. Isso ocorre geralmente quando existem restrições à alocação dos recursos, tais como: altos custos de movimentação de máquinas e equipamentos, área disponível, processos inflamáveis, vibrações e outros. A Figura 1 exibe um sistema de manufatura celular, enquanto a Figura 2 exibe um sistema de manufatura com arranjo funcional, em que as máquinas do mesmo tipo encontram-se concentradas em um mesmo departamento.

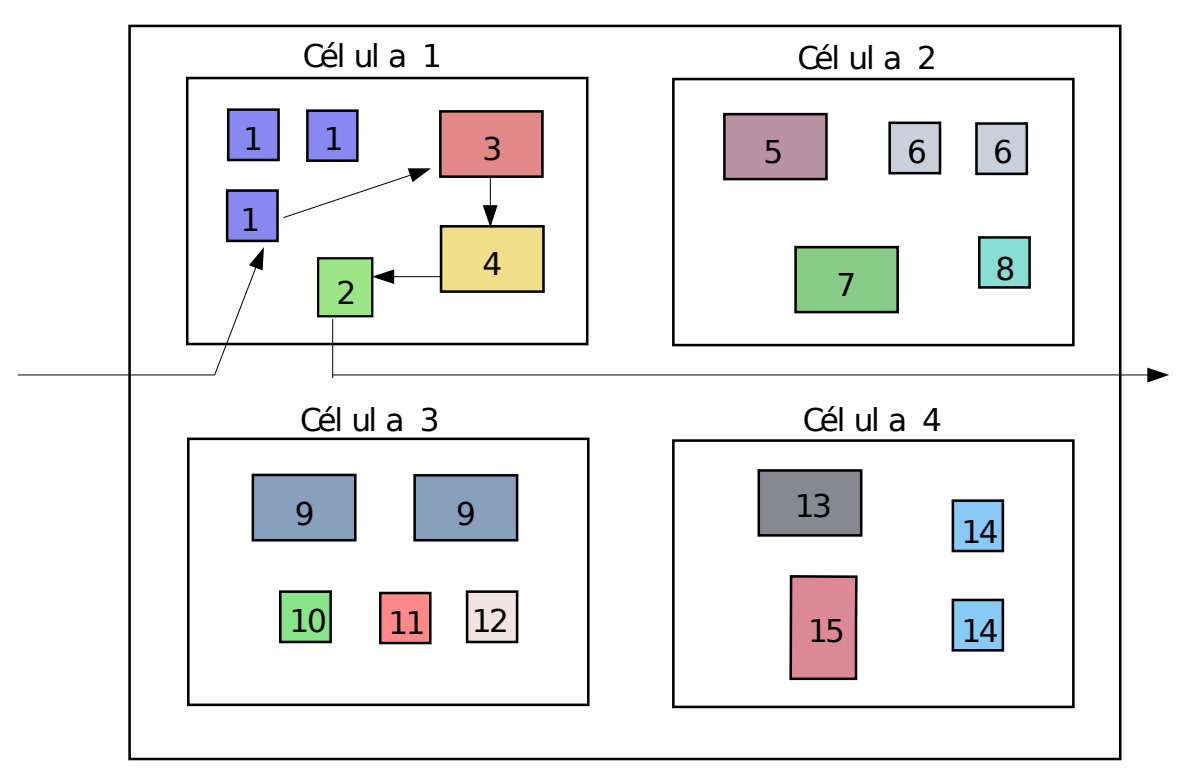

Figura 1. Um sistema de manufatura celular 


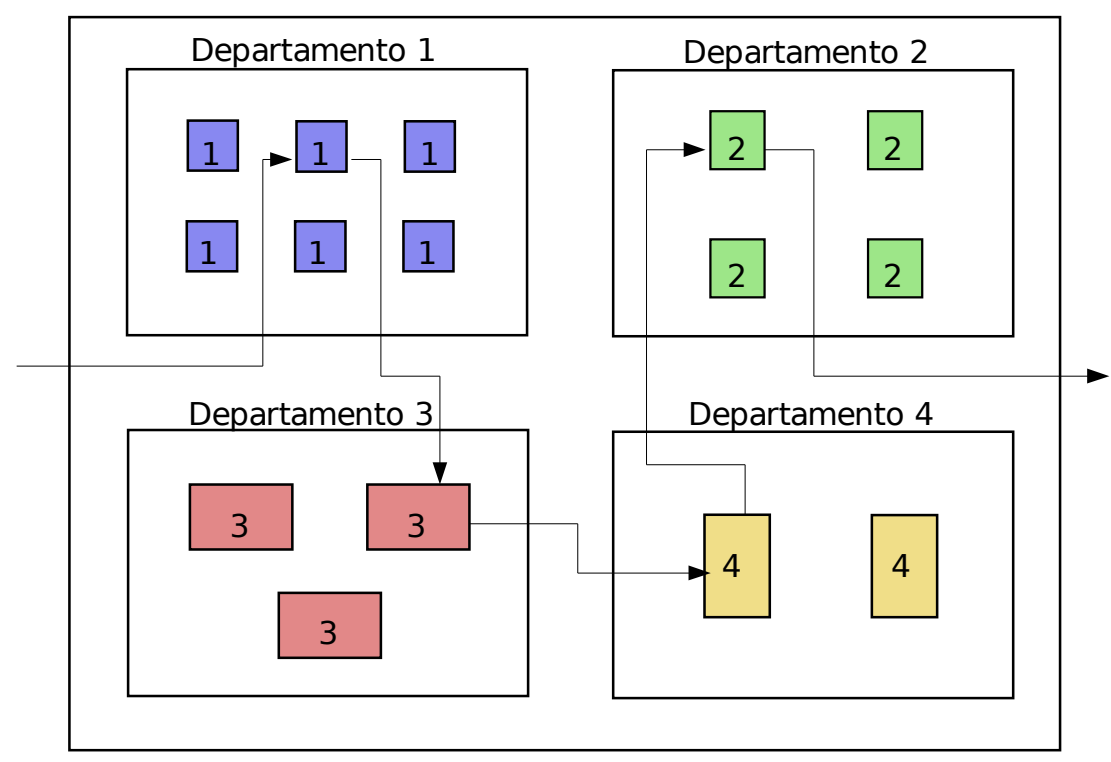

Figura 2. Um sistema de manufatura com arranjo físico funcional

A literatura relata vários benefícios da implementação da manufatura celular nas indústrias. Entre eles, os principais são enumerados a seguir (WEMMERLOV; JOHNSON, 1997):

- Redução de inventário em processo: Quando os recursos necessários à manufatura de uma família de produtos estão mais perto uns dos outros, há necessidade de menores lotes de produção, reduzindo a quantidade de produtos esperando processamento;

- Redução de tempo de atravessamento (lead time): Decorre da redução de inventário em processo, por meio da Lei de Little $(L=\lambda W$, em que $\mathrm{L}$ é o inventário em processo, $\lambda$ a taxa de processamento e $\mathrm{W} o$ tempo de atravessamento.);

- Simplificação do planejamento e controle da produção: Como os recursos são dedicados às famílias de produtos, a complexidade do planejamento e controle da produção é menor do que aquela observada em sistemas do tipo job shop nos quais os padrões de fluxo são menos 
previsíveis e qualquer máquina pode processar qualquer produto;

- Controle visual: A proximidade dos recursos necessário à fabricação de uma família de produtos facilita o controle visual do fluxo de trabalho.

- Polivalência da mão-de-obra: Células promovem o desenvolvimento das habilidades dos operadores e o seu empowerment ${ }^{3}$, uma vez que o responsável pela célula também é responsável pela qualidade do produto.

No entanto, existem desvantagens e barreiras à implementação de sistemas celulares:

- Exigência maior de capacidade: Um sistema de manufatura celular, exige maior capacidade de produção que um sistema funcional, pois em geral envolve a dedicação de máquinas às células;

- Resistência dos operários: Pode haver resistência dos trabalhadores da fábrica à adoção de células de produção devido à impressão de aumento de trabalho sem a contrapartida no aumento salarial;

- Impossibilidades físicas: Alguns processos de produção são mais difíceis de serem organizados de forma celular devido ao grande porte dos equipamentos, ou outras limitações de ordem física;

\subsection{Tipologia de sistemas de manufatura celular}

A tipologia de células de produção é bastante diversa. Em geral, as células de produção podem se diferenciar quanto às seguintes características:

3 Existem registros de tradução do termo como "empoderamento". 
Distribuição espacial:

- Células com máquinas fisicamente próximas: Essas células são as mais comuns. As máquinas encontram-se visualmente próximas, de tal forma que é possível identificar prontamente os recursos necessários à fabricação de uma família de produtos. Neste caso, o arranjo físico é definido pelas células de produção, de modo que há liberdade apenas no posicionamento relativo das máquinas dentro da célula;

- Células virtuais: As máquinas e equipamentos não se encontram em proximidade. Em geral, estão espalhados pela fábrica, mas são dedicados a certas famílias de produtos. A dedicação dos recursos pode ser temporária ou permanente. Neste caso, não há limitações quanto ao arranjo físico, podendo ele ser um arranjo funcional, ou um arranjo distribuído. Estudos relacionados às células virtuais são encontrados nos artigos de Suresh e Slomp (2005) e Nomden, Slomp e Suresh (2006). A Figura 3 exibe um exemplo de célula virtual.

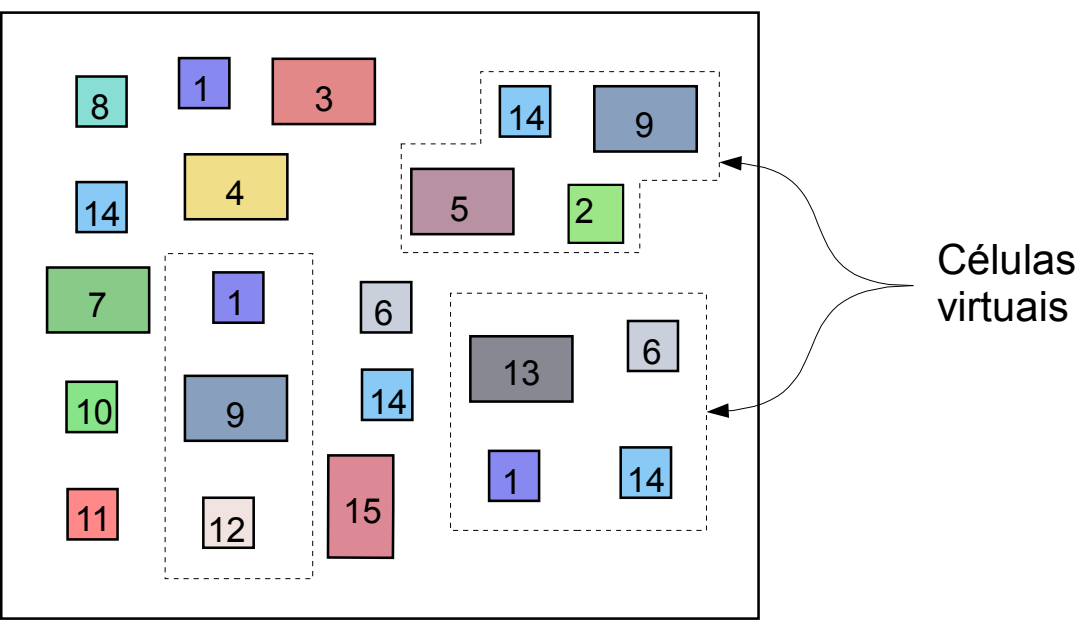

Figura 3. Células virtuais em um arranjo físico distribuído (BENJAAFAR; HERAGU; IRANI, 2002) 
Independência e dedicação:

- Células dedicadas ou independentes: São células nas quais os produtos alocados são completamente fabricados dentro da célula. $O$ fluxo intercelular deve ser minimizado ao se projetar células independentes. Os únicos fluxos que devem existir são fluxos de entrada e saída da célula, ou seja, fluxo de entrada de matéria-prima, e saída do produto acabado;

- Células não-dedicadas, ou interdependentes: Neste caso é permitido o fluxo intercelular. Isso acontece principalmente quando a fabricação de um produto completamente dentro de uma célula é inviável. Em geral, a impossibilidade está relacionada a exigências de capacidade adicional. $\mathrm{O}$ fluxo intercelular é então desejável, possibilitando o acesso dos produtos aos recursos de células às quais não estão associados, ou o acesso a uma célula que possui os recursos mais escassos (que possuem restrições quanto à duplicação, entre elas, investimento elevado ou limitações físicas de área e instalação).

Flexibilidade:

- Células convencionais: As células de produção convencionais baseiam-se na existência de similaridades entre os produtos, por meio das quais podem ser geradas famílias de produtos. As células são então formadas com o objetivo de serem capazes de manufaturar 
completamente uma família. Isso produz vantagens quanto à diminuição do tempo de setup e diminuição da movimentação de materiais, em virtude da proximidade entre as máquinas;

- Células fractais: Baseiam-se na premissa de que sistemas celulares fortemente dedicados a famílias de produtos podem logo se tornar ineficientes, devido às mudanças nos produtos e em suas demandas. $\mathrm{O}$ objetivo da célula fractal é então ser suficientemente flexível para produzir quase qualquer produto, independentemente do seu roteiro de fabricação. Dessa forma, uma célula fractal assemelha-se a uma "fábrica dentro da fábrica". Bons estudos sobre as células fractais foram publicados por Venkatadri, Rardin e Montreuil (1997); Montreuil, Venkatadri e Rardin (1999); Askin, Ciarallo e Lundgren (1999); e Saad e Lassila (2004). A Figura 4 exibe um exemplo de células fractais.

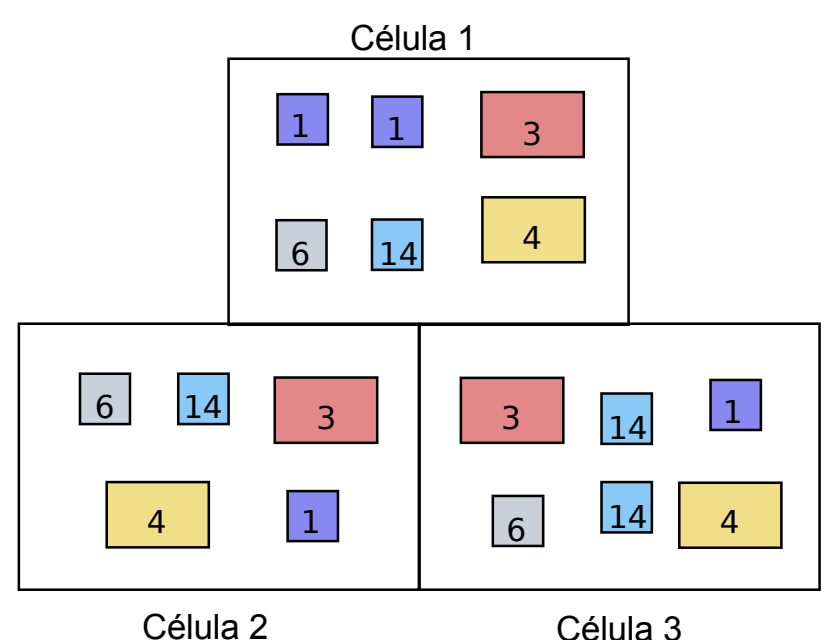

Figura 4. Células fractais (VENKATADRI; RARDIN; MONTREUIL, 1997) 


\subsection{Dimensionamento da capacidade dos recursos}

A partir da decisão de se montar uma fábrica para produzir um certo tipo de produto, procede-se à escolha dos tipos de máquinas e equipamentos necessários, e sua quantidade. Para isso, deve-se fazer uma estimativa da demanda futura de cada tipo de operação, com base nas especificações dos produtos e em suas demandas de mercado.

Em seguida, deve-se dimensionar a capacidade necessária de cada tipo de máquina, por meio da equação (1).

$$
\mathrm{R}_{\mathrm{i}}=\left\lceil\frac{\sum_{\mathrm{j}=1}^{\mathrm{n}} \mathrm{D}_{\mathrm{j}} \mathrm{t}_{\mathrm{ij}} \mathrm{x}_{\mathrm{ij}}}{\mathrm{T}_{\mathrm{i}}}\right\rceil \quad \forall \mathrm{i} \in\{1,2, \ldots, \mathrm{N}\}
$$

Em que:

$\mathrm{R}_{\mathrm{i}}$ - Número de réplicas do tipo i necessárias para o atendimento da demanda total esperada;

$\mathrm{D}_{\mathrm{j}}$ - Demanda do produto j no período;

$\mathrm{t}_{\mathrm{ij}}$ - Tempo de processamento do produto j na máquina $\mathrm{i}$;

$\mathrm{x}_{\mathrm{ij}}$ - Variável binária que assume valor 1 se o produto j é processado na máquina i, e 0 caso contrário;

$\mathrm{T}_{\mathrm{i}}$ - Tempo total disponível no período para o tipo de máquina i;

$\lceil\mathrm{x} \mid$ - Função que retorna o menor inteiro superior a $\mathrm{x}$;

n - Número de produtos;

N - Número de tipos de máquinas. 


\subsection{Formação de células de manufatura}

Após a determinação da capacidade necessária, é preciso formar as células de produção e as famílias de produtos que serão alocadas à cada célula. Existem diversos modelos e técnicas para isso.

King (1980) foi um dos primeiros a propor um procedimento heurístico para formação de células de produção. Segundo seu procedimento, primeiro se constrói uma matriz de incidência peça-máquina. Nessa matriz, as linhas representam os tipos de máquinas, e as colunas representam os produtos. Cada elemento $a_{i j}$ da matriz assume valores binários, em que $a_{i j}=1$ significa que o produto j requer processamento na máquina $\mathrm{i}$, enquanto $\mathrm{a}_{\mathrm{ij}}=0$ significa que o produto j não requer processamento na máquina i. A Tabela 1 exibe um exemplo de uma matriz de incidência peça-máquina.

Tabela 1 - Matriz de incidência peça-máquina

\begin{tabular}{cccccc}
\hline \multirow{2}{*}{ Máquinas } & \multicolumn{5}{c}{ Peças } \\
\cline { 2 - 6 } & 1 & 2 & 3 & 4 & 5 \\
\hline 1 & 1 & 0 & 1 & 0 & 0 \\
2 & 0 & 1 & 1 & 0 & 1 \\
3 & 1 & 0 & 0 & 1 & 0 \\
4 & 0 & 0 & 1 & 0 & 1 \\
\hline
\end{tabular}

A formação de células nessa representação acontece a partir da transformação dessa matriz em uma matriz de blocos diagonalizada. A Tabela 2 exibe um exemplo de tal matriz. Nela, pode-se observar a formação de 2 células de produção e 2 famílias de produtos. A primeira célula é composta pelas máquinas 1 e 3, e processa a família dos produtos 1 e 4 . A segunda célula é formada pelas máquinas 2 e 4, a qual processa a família dos produtos 2, 3 e 5. 
Tabela 2- Matriz de blocos diagonalizada

\begin{tabular}{cccccc}
\hline \multirow{2}{*}{ Máquinas } & \multicolumn{5}{c}{ Peças } \\
\cline { 2 - 6 } & 1 & 4 & 3 & 5 & 2 \\
\hline 1 & 1 & 1 & 0 & 0 & 0 \\
3 & 1 & 1 & 0 & 0 & 0 \\
2 & 0 & 0 & 1 & 1 & 1 \\
4 & 0 & 0 & 1 & 1 & 1 \\
\hline
\end{tabular}

É possível observar também na matriz formada, que todos os produtos são completamente fabricados dentro da sua respectiva célula. Ou seja, as células são independentes, visto que não há transporte de material entre as duas. Essa é uma situação ideal. Na prática, de acordo com as seqüências de fabricação dos produtos, é improvável que essa partição ideal de células e de produtos exista. Logo, deseja-se então encontrar a matriz de bloco cujas células sejam o mais independentes quanto possível (Tabela 3).

Em uma matriz de blocos otimamente diagonalizada, o número de elementos excepcionais e elementos vazios é o mínimo possível para aquele conjunto de produtos. Elementos excepcionais ocorrem quando algum produto precisa fazer uma operação fora da célula ao qual foi alocado. São representados por valores ' 1 ' fora das regiões sombreadas da matriz. Vazios ocorrem quando uma peça não necessita de uma máquina alocada à célula na qual é processada. São representados por valores '0' dentro das regiões sombreadas.

A dificuldade em se encontrar a matriz de blocos diagonalizada com menor número de elementos excepcionais e vazios é que trata-se de um problema NP-difícil, e, até o momento, não se conhecem algoritmos eficientes para encontrar a solução ótima para problemas de escala real. Em conseqüência, o objetivo passa a ser encontrar uma solução satisfatória por meio de um procedimento heurístico. 
Tabela 3 - Exemplo de matriz com elementos excepcionais e vazios

\begin{tabular}{cccccc}
\hline \multirow{2}{*}{ Máquinas } & \multicolumn{5}{c}{ Peças } \\
\cline { 2 - 6 } & 1 & 2 & 3 & 4 & 5 \\
\hline 1 & 1 & 0 & 1 & 0 & 0 \\
2 & 0 & 1 & 1 & 0 & 1 \\
3 & 1 & 0 & 0 & 1 & 0 \\
4 & 0 & 0 & 1 & 0 & 1 \\
\hline
\end{tabular}

Em seguida, serão apresentadas algumas heurísticas propostas para a obtenção de uma boa matriz de blocos diagonalizada.

\subsubsection{Manipulação direta da matriz de incidência peça-máquina}

Heurística Rank Order Clustering - ROC

A heurística ROC - Rank Order Clustering (Clusterização por ordem de ranqueamento) manipula diretamente as linhas e colunas da matriz de incidência de forma a obter os agrupamentos de peças e máquinas. Para isso, a heurística atribui a cada vetor binário da matriz o seu equivalente em número decimal. Por exemplo, na Tabela 1, a linha 2, que representa a máquina 2, é o seguinte vetor binário:

01101

Fazendo-se a conversão para número decimal, obtém-se:

$01101=0 \times 2^{4}+1 \times 2^{3}+1 \times 2^{2}+0 \times 2^{1}+1 \times 2^{0}=13$

A seqüência de passos da heurística ROC é exibida no Quadro 1. 
Passo 1: Para cada linha $m=1,2 . ., M$, compute o equivalente decimal $c_{m}$ por meio da equação $\quad \mathrm{c}_{\mathrm{m}}=\sum_{1}^{\mathrm{P}} 2^{\mathrm{p}-\mathrm{p}} \mathrm{a}_{\mathrm{pm}}$, em que $\mathrm{a}_{\mathrm{pm}} \in\{0,1\}$ Reordene as linhas em ordem decrescente de $\mathrm{c}_{\mathrm{m}}$. Em caso de empate, mantenha a ordem original;

Passo 2: Repita o passo 1 para as colunas;

Passo 3: Se a nova matriz for idêntica à anterior, então pare. Caso contrário, volte ao passo 1.

Quadro 1. Pseudo-código da heurística ROC (SINGH; RAJAMANI, 1996)

\section{Limitações da heurística ROC}

Uma das principais limitações dessa heurística ocorre quando a matriz de incidência é muito grande. Neste caso, os equivalentes decimais dos vetores binários são números muito grandes, o que gera dificuldade para armazenamento na memória. Na maioria dos computadores, o maior inteiro possível é $2^{48}-1$, ou seja, o número máximo possível de linhas ou colunas é 47 . Também há a tendência de acúmulos de 1's no canto esquerdo superior, devido à natureza exponencial da conversão de binários para decimais, em que 1's mais à esquerda têm expoentes maiores e dominam a grandeza do decimal obtido.

Outras limitações estão relacionadas a características comuns a outras heurísticas, como: dependência da solução inicial e falta de garantia quanto à geração da matriz diagonalizada ótima.

Heurística Direct Clustering Analysis - DCA (Análise de clusterização direta)

Essa heurística é muito semelhante a ROC. A diferença principal consiste no uso direto do número de células positivas nas linhas e colunas, em vez de 
transformar o vetor binário em um decimal correspondente. O Quadro 2 contém o pseudo-código dessa heurística.

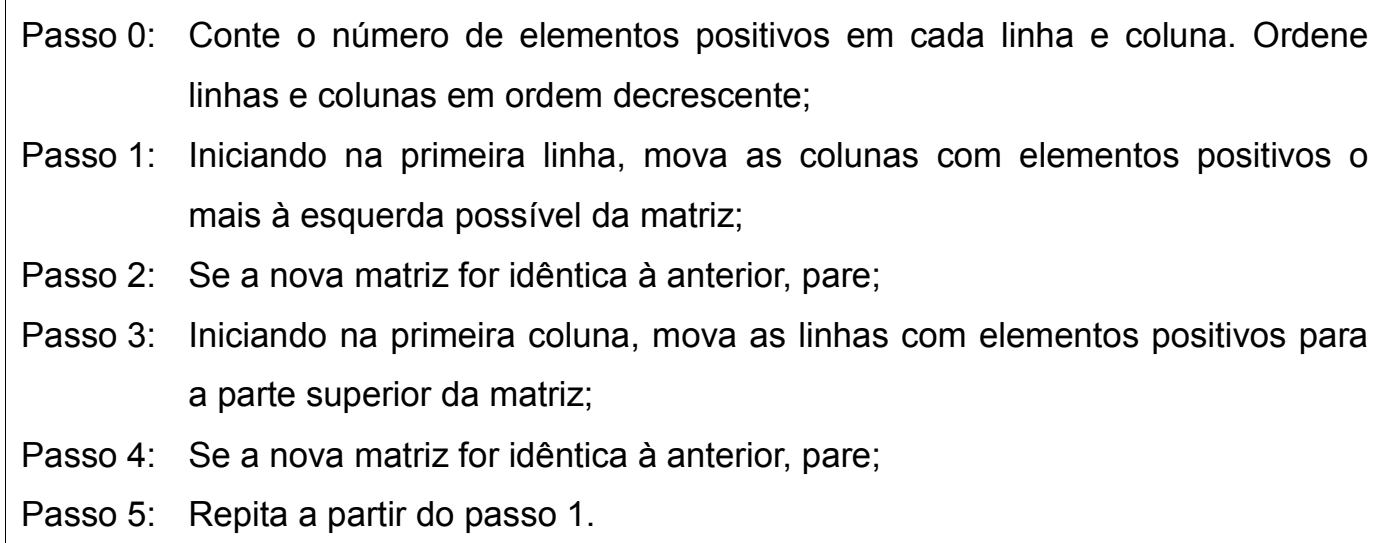

Quadro 2. Pseudo-código do algoritmo DCA (CHU; TSAI, 1990)

2.4.2 Técnicas baseadas em coeficientes de similaridade e algoritmos de análise de agrupamentos

Ao contrário das técnicas anteriormente apresentadas, as quais manipulam diretamente a matriz de incidência peça-máquina, as técnicas baseadas em coeficientes de similaridade utilizam essa medida para estabelecer um "grau de semelhança" entre um par de máquinas ou um par de produtos (YIN; YASUDA, 2006).

A análise de agrupamento é uma técnica cujo objetivo é identificar grupos de entidades semelhantes em um conjunto grande de dados (FRALEY; RAFTERY, 1998). Ela se divide em 2 tipos: técnicas diretas e técnicas hierárquicas.

As técnicas diretas tentam formar um número previamente especificado de grupos. Os algoritmos baseados nessa abordagem normalmente formam os $\mathrm{k}$ grupos iniciais de forma aleatória, e, à medida que são iterados, movimentam os elementos entre os grupos de forma a maximizar a similaridade dos elementos que 
fazem parte de um mesmo grupo (MITCHELL, 1997). O principal algoritmo desta classe é o "K - médias".

Enquanto isso, as abordagens hierárquicas geralmente não utilizam formação aleatória de grupos, consistindo em um procedimento intrinsecamente determinístico. A idéia é comparar dois a dois os elementos quanto à sua similaridade e progressivamente formar os grupos.

\section{Coeficiente de similaridade}

Um coeficiente de similaridade é uma medida aplicada a 2 elementos de uma mesma natureza cujo objetivo é estabelecer quão semelhantes esses dois elementos são (SEIFODDINI, 1988). Em aplicações de formação de células de produção, comumente tenta-se estabelecer a similaridade entre um par de máquinas ou um par de produtos. Existem muitos coeficientes de similaridade propostos na literatura. Em seguida, são descritos alguns dos mais empregados. Para uma revisão completa, consultar o artigo de Yin e Yasuda (2006).

Coeficiente de Jaccard

Este coeficiente é o mais utilizado em aplicações de formação de células de produção (YIN; YASUDA, 2006). Sua definição é dada a seguir:

Sejam i e j duas máquinas. A similaridade entre as duas é dada pela equação (2).

$$
\mathrm{S}_{\mathrm{ij}}=\frac{\mathrm{a}}{(\mathrm{a}+\mathrm{b}+\mathrm{c})} \quad 0 \leq \mathrm{S}_{\mathrm{ij}} \leq 1
$$


Em que:

a-número de peças que visitam ambas as máquinas;

b-número de peças que visitam a máquina i mas não visitam a máquina j; c-número de peças que visitam a máquina j mas não visitam a máquina i;

O valor de Sij varia entre 0 (total dissimilaridade), quando o número de peças que visitam ambas as máquinas é zero, e 1 (total similaridade), quando nenhuma peça visita a máquina i ou j sem visitar a outra.

\section{Medida de distância Euclidiana}

É utilizada como medida de "dissimilaridade", ou seja, ao contrário dos coeficientes de similaridade, 2 entidades (máquinas ou peças) serão idênticas se a distância entre as duas for zero. A equação (3) define a distância Euclidiana entre duas máquinas ( ou peças).

$$
\mathrm{S}_{\mathrm{ij}}=\left(\sum_{\mathrm{k}=1}^{\mathrm{M}}\left|\mathrm{a}_{\mathrm{ki}}-\mathrm{a}_{\mathrm{kj}}\right|^{2}\right)^{1 / 2} \quad \mathrm{~S}_{\mathrm{ij}} \geq 0
$$

\section{Em que :}

$a_{k i}$ - Elemento ki do vetor binário correspondente retirado da matriz de incidência peça - máquina;

$\mathrm{S}_{\mathrm{ij}}$ - Coeficiente de similaridade. 
62

\section{Medida de distância Hamming}

Essa medida de distância, diferentemente da medida Euclidiana, assume apenas valores inteiros. É definida pela equação (4).

$$
\mathrm{S}_{\mathrm{ij}}=\sum_{\mathrm{i}=1}^{\mathrm{M}} \delta\left(\mathrm{a}_{\mathrm{ki}}, \mathrm{a}_{\mathrm{kj}}\right) \quad 0 \leq \mathrm{S}_{\mathrm{ij}} \leq \mathrm{M}
$$

Em que:

$$
\delta\left(\mathrm{a}_{\mathrm{ki}}, \mathrm{a}_{\mathrm{kj}}\right)=\left\{\begin{array}{lll}
1 & \text { se } & \mathrm{a}_{\mathrm{ki}} \neq \mathrm{a}_{\mathrm{kj}} \\
0 & \text { se } & \mathrm{a}_{\mathrm{ki}}=\mathrm{a}_{\mathrm{kj}}
\end{array}\right\}
$$

Em seguida, serão descritos algoritmos de análise de agrupamentos com coeficientes de similaridade muito utilizados em formação de células de produção.

\section{Algoritmo K - médias}

O algoritmo $\mathrm{K}$ - médias é não-hierárquico e utiliza uma solução inicial a partir da qual ele realiza umas busca gradativa por melhores grupos. Seus passos de execução estão descritos no Quadro 3. 
Passo 0: Agregue aleatoriamente as máquinas (ou peças) em $\mathrm{K}$ grupos;

Passo 1: Para cada grupo, calcule o centróide;

Passo 2: Para cada máquina, calcule a similaridade entre a mesma e cada centróide dos K grupos;

Passo 3: Se uma máquina tiver similaridade maior com o centróide de outro grupo que com o seu próprio, mova a máquina para esse outro grupo;

Passo 4: Recalcule os centróides dos grupos;

Passo 5: Repita os passos 2 a 4 até que os grupos não se modifiquem mais.

Quadro 3. Pseudo-código do algoritmo K-médias

Algoritmos hierárquicos

Single Linkage Clustering Algorithm - SLC (Algoritmo de clusterização por ligação simples)

O algoritmo SLC executa o agrupamento hierárquico das máquinas ou peças. Seu pseudo-código é descrito no Quadro 4.

\footnotetext{
Passo 0: Considere cada máquina (peça) inicial como um grupo unitário;

Passo 1: Para cada máquina (peça), calcule o coeficiente de similaridade;

Passo 2: Encontre o par com maior similaridade e agregue em um novo grupo;

Passo 3: Calcule o coeficiente de similaridade entre pares de grupos. O coeficiente de similaridade entre os grupos i e j é dado pelo menor coeficiente entre os pares individuais de máquinas (peças) de i e j;

Passo 4: Encontre o par de grupos com maior similaridade e os agrupe;

Passo 5: Se todas as máquinas (peças) tiverem sido agrupadas em um único grupo, pare. Senão, retorne ao passo 3.
}

Quadro 4. Pseudo-código do algoritmo SLC

Ao final da execução, uma árvore chamada "dendograma" terá sido formada, exibindo todo o processo de agregação, desde as máquinas unitárias, até todas as máquinas compuserem apenas um grupo. A Figura 5 exibe um exemplo de 
dendograma.

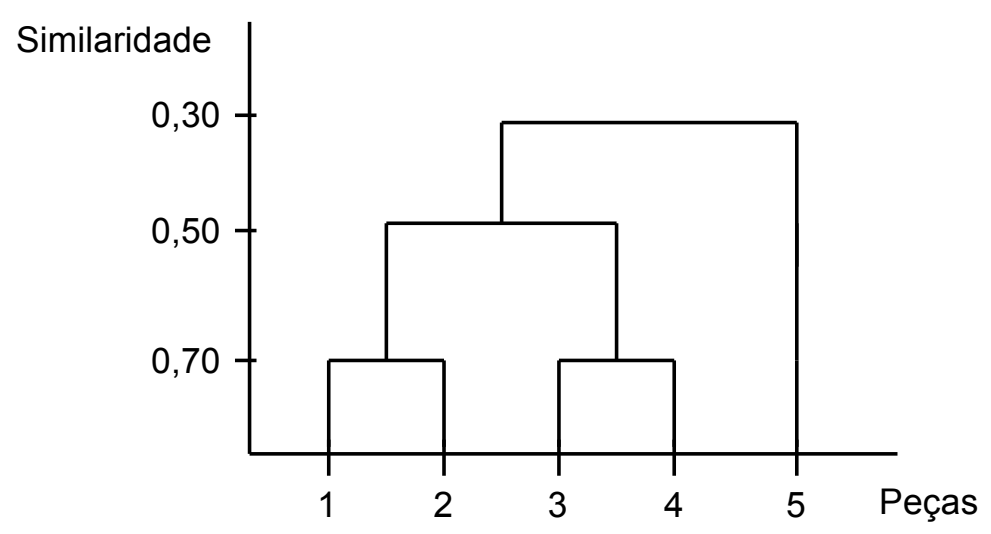

Figura 5. Dendograma representando o processo de formação hierárquica de células de produção

Consultando-se o dendograma, é possível definir as células de produção dado o número desejado de células, ou um valor de corte para a similaridade.

Average Linkage Clustering Algorithm - ALC (Algoritmo de clusterização por ligação média) e Complete Linkage Clustering Algorithm - CLC (Algoritmo de clusterização de ligação completa)

Ambos os algoritmos ALC e CLC diferenciam-se do SLC no cálculo do coeficiente de similaridade entre um par de grupos. Enquanto no SLC a similaridade entre dois grupos i e j é dada pela maior similaridade entre dois elementos individuais $a_{i}$ e $a_{j}$, no CLC a similaridade é dada pela menor similaridade entre dois elementos individuais. Já no ALC, a similaridade entre 2 grupos é dada pela similaridade média entre seus elementos. 


\subsection{Medidas de desempenho de células de manufatura}

Muitas medidas têm sido utilizadas na indústria e na academia para avaliar a qualidade de um sistema de manufatura celular. O problema de formação de células, como vários outros problemas em Manufatura, envolve múltiplos objetivos (MANSOURI; MOATTAR; NEWMAN, 2000). De acordo com as estratégias de negócio e de manufatura, o projetista pode escolher otimizar uma medida de desempenho, ou estabelecer um trade-off entre diversos objetivos. A seguir são relacionadas algumas das medidas mais comuns na literatura e na indústria.

\section{Movimentação intercelular de material}

Como um dos objetivos da manufatura celular é obter células independentes, qualquer tipo de movimentação de material intercelular é indesejada. Um produto que requeira processamento em múltiplas células torna o controle de produção mais complicado, desequilibra o balanceamento da carga de trabalho, e necessita de mais recursos de movimentação.

No entanto, observa-se na prática que é bastante comum a movimentação de lotes entre células devido à dificuldade em se formar células independentes. Wemmerlöv e Johnson (2000) afirmam que muitas células de manufatura não processam completamente suas famílias de produtos, as quais necessitam de recursos de outras partes do sistema para serem completadas. 
Kher e Jensen (2002, p. 162) adicionam ainda as seguintes considerações:

\begin{abstract}
For reasons such as limited availability, size, and toxicity, certain equipment cannot be physically located in cells. Examples of such equipment include special types of finishing operations, plating, heat-treating, cleansing, and degreasing. When it is not possible to dedicate the equipment necessary to process a family completely in its own cell, intercell flow of material is required. ${ }^{4}$
\end{abstract}

Em suma, apesar de ser desejável a formação de células independentes, na prática tenta-se projetar um sistema celular em que a interação entre células seja o mínimo possível.

Movimentação de materiais dentro da célula

Essa medida de desempenho está relacionada principalmente ao arranjo físico (layout) da célula, ou seja, à posição relativa das máquinas. O layout da célula influencia o padrão de fluxo entre as máquinas, de acordo com a seqüência de fabricação dos produtos, e pode demandar maior capacidade do sistema de movimentação interna caso não seja bem projetado (GUPTA et al., 1996).

Nível de balanceamento

Células de produção assemelham-se a linhas de produção com tamanhos de lotes pequenos ou médios (PATTERSON; FREDENDALL; CRAIGHEAD, 2002). Logo, células de produção devem ter sua carga balanceada para que que os níveis

4 Devido à disponibilidade limitada, tamanho e toxicidade, certos equipamentos não podem ser fisicamente alocados em células. Exemplos incluem tipos especiais de operações de acabamento, banho químico, tratamento térmico, limpeza química, e retirada de impurezas. Quando não é possível dedicar os equipamentos necessários para processar uma família de produtos completamente em sua própria célula, se faz necessária a movimentação entre células. (tradução própria) 
de estoque em processo sejam menores e tenham menor variabilidade.

Ao se avaliar uma alternativa de projeto de células de produção, o balanceamento das células é medido com base nas demandas dos produtos e nos tempos de processamento nas máquinas. Uma célula balanceada possui máquinas com carga de trabalho semelhante.

Inventário em processo e tempo de atravessamento

Essas medidas de desempenho operacional são de difícil predição na fase de projeto, pois são fortemente influenciadas pela variação da demanda, pelo mix de produção, e pelas regras operacionais de controle de produção. Não obstante, pesquisadores, consultores e gerentes de produção têm crescentemente se preocupado com o problema de projeto de sistemas de manufatura celular que favoreçam baixos inventários. Modelos analíticos da Teoria das Filas e modelos de Simulação têm sido propostos para o auxílio na avaliação de medidas operacionais de fluxo em sistemas de manufatura.

\section{Medidas de flexibilidade}

A partir dos anos 90, mudanças econômicas mundiais modificaram os padrões de exigência do consumidor, gerando um mercado volátil e de difícil previsibilidade. Os produtos passaram a ter um ciclo de vida muito curto e a variabilidade de suas demandas aumentou. Esse fato criou a necessidade de que os sistemas de manufatura sejam mais flexíveis para absorver mudanças nos níveis de demanda e nos requisitos de fabricação dos produtos. 
Vakharia, Askin e Selirn (1999) definem os seguintes tipos de flexibilidade que um sistema de manufatura celular pode apresentar:

- Flexibilidade de tipo de máquina: Possibilidade de que as máquinas em uma célula sejam capazes de processar um número grande de operações distintas;

- Flexibilidade de roteamento: Habilidade de um sistema de manufatura em processar partes em múltiplas células;

- Flexibilidade de volume: Habilidade de um sistema de manufatura em lidar com variações de demanda;

- Flexibilidade de mix de produção: Habilidade de um sistema de manufatura em tratar diferentes composições de volume e variedade de produtos com pequena perturbação nas operações;

\subsection{Relação entre capacidade e desempenho em células de manufatura}

Os modelos de sistemas de manufatura desenvolvidos de acordo com princípios de Teoria das Filas provêem intuições valiosas quanto à relação de medidas de "congestionamento" do sistema e a capacidade de processamento destes. No contexto de manufatura, duas das mais importantes dessas medidas são o inventário em processo (Work-in-process, WIP) e o tempo de atravessamento (lead time).

Deve-se atentar para dois fenômenos relacionados à variabilidade e que devem ser considerados para o projeto e controle de sistemas de manufatura: 0 crescimento exponencial do WIP, e a agregação da variabilidade (variability pooling). 
O crescimento exponencial do WIP diz respeito ao fato do WIP crescer exponencialmente com o aumento da utilização dos recursos. Isto é, à medida que a utilização de um sistema de manufatura se aproxima de $100 \%$, o WIP tende ao infinito. Esta é a razão pela qual nunca se consegue atingir uma utilização de $100 \%$ dos recursos. O Gráfico 1 exibe esse fenômeno.

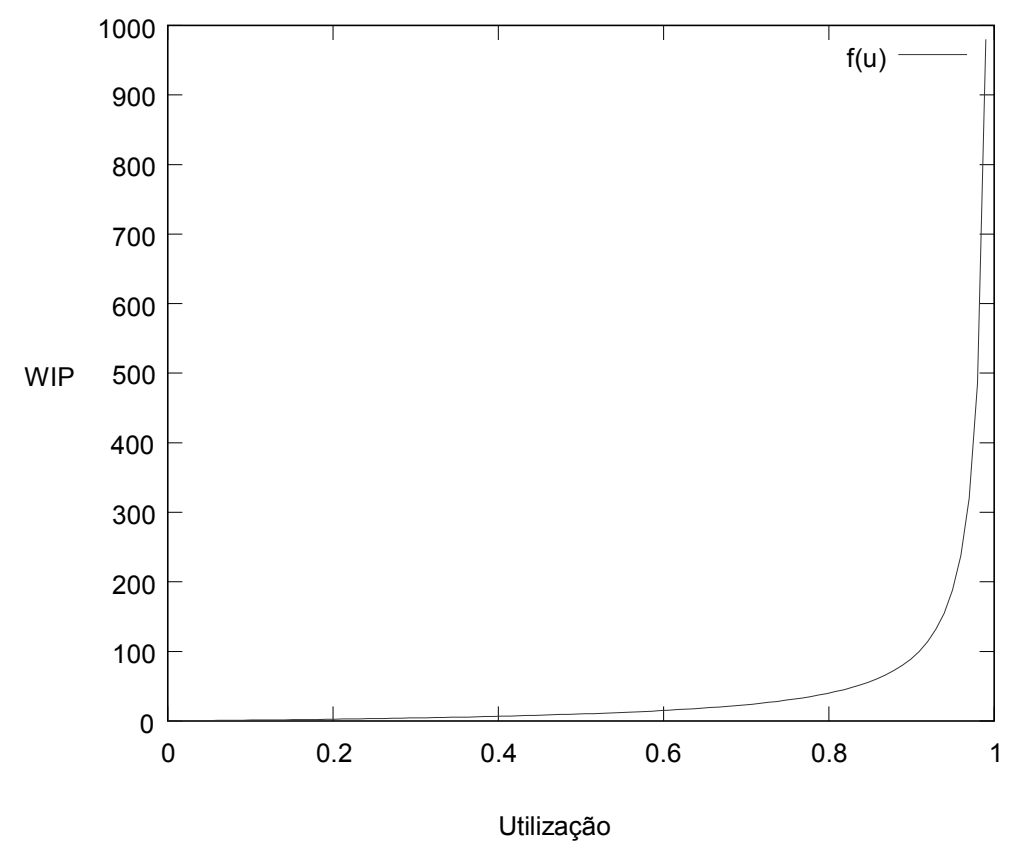

Gráfico 1. Aumento de WIP à medida que a utilização se aproxima de $100 \%$

O Gráfico 1 pode ser obtido a partir da equação (6). Essa equação, também chamada de equação VUT (Variability, Utilization and Time), é uma aproximação do tempo de espera na fila por um recurso com $\mathrm{m}$ processadores (ou servidores), em que o tempo de chegada e o tempo de processamento seguem uma distribuição de probabilidades genérica (ou seja, em um sistema GI/G/m) (WHITT, 1993). 


$$
\mathrm{W}_{\mathrm{q}}=\left(\frac{\mathrm{C}_{\mathrm{a}}+\mathrm{C}_{\mathrm{e}}}{2}\right) \frac{\rho^{\sqrt{2 \mathrm{~m}+1}-1}}{\mathrm{~m}(1-\rho)} \mathrm{t}_{\mathrm{e}}
$$

Em que:

$\mathrm{W}_{\mathrm{q}}$ - Tempo médio de espera em fila;

$\mathrm{C}_{\mathrm{a}}$ - Coeficiente de variação do processo de chegada na fila;

$\mathrm{C}_{\mathrm{e}}$ - Coeficiente de variação do tempo de processamento;

$\rho$ - Nível de utilização dos recursos;

m - Número de servidores (máquinas) em paralelo;

$t_{e}-$ Tempo de processamento.

O WIP se relaciona com o tempo de espera em fila por meio da Lei de Little (equação (7)) e da equação (8).

$$
\begin{gathered}
\mathrm{L}=\lambda \mathrm{W} \\
\mathrm{W}=\mathrm{W}_{\mathrm{q}}+\mathrm{t}_{\mathrm{e}}
\end{gathered}
$$

Em que:

L - WIP médio;

$\lambda$ - Taxa de chegada da demanda;

$\mathrm{W}$ - Tempo médio no sistema (tempo de atravessamento).

Como a utilização dos recursos pode ser reduzida com o aumento de capacidade, dado que a demanda permanece constante, há então um trade-off 
entre capacidade e WIP. Ou seja, dada um demanda constante, quanto mais capacidade ociosa, menos WIP.

O segundo fenômeno importante é o de agregação de variabilidade. Segundo ele, ao se comparar dois sistema com filas de mesma capacidade no qual em um todos os recursos são compartilhados, e em outro nenhum recurso é compartilhado, o primeiro terá menor WIP e menor tempo de espera. Isso é ilustrado na Figura 6.

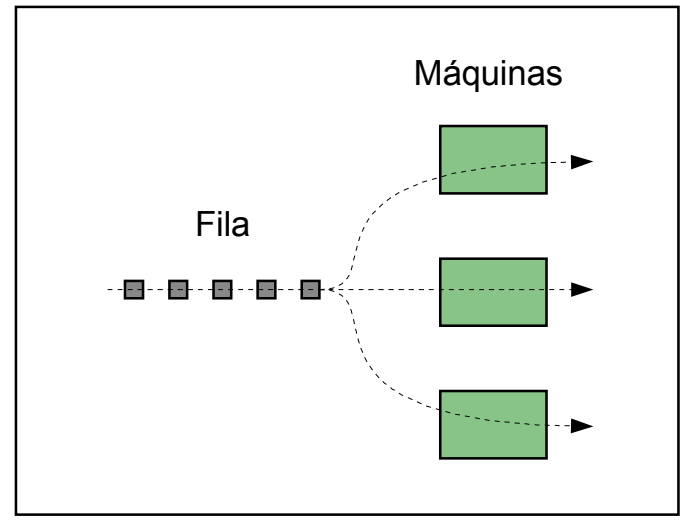

Sistema 1 - Fila agregada

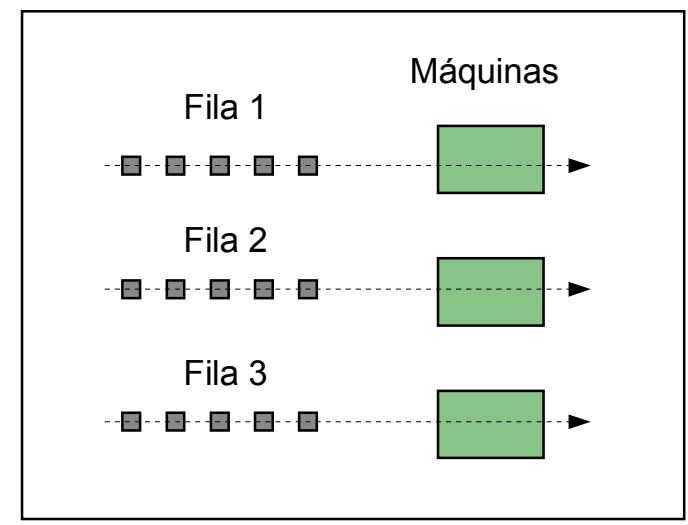

Sistema 2 - Fila desagregada

Figura 6. O sistema 1 tem menor WIP que o sistema 2 para o mesmo nível de capacidade e utilização

Em um sistema de manufatura com arranjo físico funcional, a agregação da variabilidade é total, visto que todas as réplicas de um tipo de máquina se encontram em um mesmo departamento, o qual possui em geral apenas uma fila de espera. Já em um sistema celular, as réplicas são distribuídas entre células, e o compartilhamento de réplicas envolve a movimentação intercelular. Devido a isso, o WIP total em um sistema celular pode ser maior se não se considerar outros fatores que impactam o WIP, como o sistema de movimentação e o tamanho dos lotes. 


\subsection{Formação de células com réplicas e múltiplos roteamentos}

Até recentemente, o problema de formação de células de produção era modelado levando-se em conta apenas os tipos de máquinas, e não a existência de múltiplas réplicas (JAYASWAL; ADIL, 2004). Desde que, em uma fábrica real, o número de máquinas de um mesmo tipo é comumente maior que 1 , as técnicas até então utilizadas implicavam que todas as réplicas de máquina deveriam ser alocadas à mesma célula. Isso acontece em métodos de manipulação direta da matriz de incidência peça-máquina, e em métodos de análise de agrupamentos (cluster analysis), como levantado por Wu (1998, p. 2100)

Due to the capacity requirement for the products to be manufactured, the number of machines for every machine type should be determined by capacity requirement, and is a constraint to the problem of designing CMS. (...) By these methods, the shared machines are identified first based on some cell formation algorithms, then the machine duplication is made. The problem is that the shared machines identified may not actually be shared machines due to the availability of multiple machines for some machine types. Therefore, the duplication may be unnecessary and improper. When identifying the shared machines, each machine type is treated as one machine by a cell formation algorithm and the multiplicity of a machine type is not considered, which results in the improper identification of shared machines and improper machine duplication. ${ }^{5}$

No entanto, a distribuição de máquinas de um mesmo tipo entre células

diferentes pode gerar flexibilidade de roteamento no sistema de produção (ADIL; RAJAMANI; STRONG, 1996). Isso acontece porque as células passam a ter maior diversidade de processos, tornando-as capazes de manufaturar uma amplitude maior de produtos. Logo, o problema de formação de células com múltiplas réplicas de máquina é mais próximo do problema real de projeto de sistemas de manufatura

5 Devido à exigência de capacidade para o produtos a serem manufaturados, o número de réplicas para cada tipo de máquina deve ser determinado pela capacidade necessária, a qual é uma restrição para o problema de projeto de sistemas de manufatura celular. (...) Por esses métodos [manipulação de matriz peça-máquina, e análise de agrupamentos], as máquinas 'compartilhadas' são identificadas e cada tipo de máquina é tratado como uma máquina por um algoritmo de formação de células. A multiplicidade de um tipo de máquina não é considerado, o que resulta na identificação imprópria de máquinas compartilhadas e duplicação imprópria de máquinas. (Tradução própria) 
celular.

Embora a inclusão da multiplicidade de máquinas de mesmo tipo na modelagem do problema seja algo desejável, isso aumenta a sua complexidade, fazendo-se necessário novos métodos para sua solução. Wu (1998, p. 2101) comenta ainda sobre a dificuldade exibida pelo modelo de formação de células com múltiplas máquinas:

When a CMS [Cell Manufacturing System] with the existence of multiple machines for some machine types is to be designed, the problem is complicated. However, the overall performance can be improved, if the identical machines can be properly assigned into different cells. Therefore, to improve the design of CMS, we should take the advantage of multiple machines while the capacity constraint is satisfied. The problem is to develop a model for the design of CMS which can describe the number of machines for each machine type. ${ }^{6}$

Na Tabela 4 pode-se observar uma matriz peça máquina após a aplicação de um algoritmo de manipulação de linhas e colunas. Cada tipo de máquina é alocado a apenas uma célula. Por exemplo, as máquinas do tipo 1 e 2 são alocadas à mesma célula (célula 1 ). A peça 1 requer operações nas máquinas 1 e 3 , e a máquina 3 se encontra na mesma célula de 1 . No entanto, se a máquina 3 tiver múltiplas réplicas, devido à exigência de capacidade, uma réplica pode ser alocada à célula 1. Logo, a matriz diagonalizada não corresponde à realidade quanto à necessidade de duplicação de recursos, visto que mais de uma réplica da máquina tipo 3 já era prevista pelas considerações de capacidade.

6 Quando um sistema de manufatura celular com a existência de múltiplas máquinas de um mesmo tipo deve ser projetado, o problema torna-se complicado. Entretanto, o desempenho geral pode ser melhorado, se máquinas idênticas forem adequadamente alocadas em células diferentes. Portanto, para melhorar o projeto de um sistema de manufatura celular, deve-se levar em consideração a vantagem de se ter múltiplas máquinas, ao mesmo tempo que a restrição de capacidade é satisfeita. O problema é desenvolver um modelo para o projeto do sistema o qual possa descrever o número de máquinas para cada tipo de máquina. (Tradução própria) 
74

Tabela 4 - Matriz diagonal não contém informação quanto a réplicas de máquinas

\begin{tabular}{cccccc}
\hline Máquinas & \multicolumn{5}{c}{ Peças } \\
\hline 1 & 1 & 2 & 3 & 4 & 5 \\
\hline 2 & 1 & 0 & 1 & 0 & 0 \\
3 & 0 & 1 & 1 & 0 & 1 \\
4 & 1 & 0 & 0 & 1 & 0 \\
\hline
\end{tabular}

As Figuras 7 e 8 exibem um sistema celular gerado sem considerar réplicas, e outro gerado com consideração de réplicas, respectivamente.

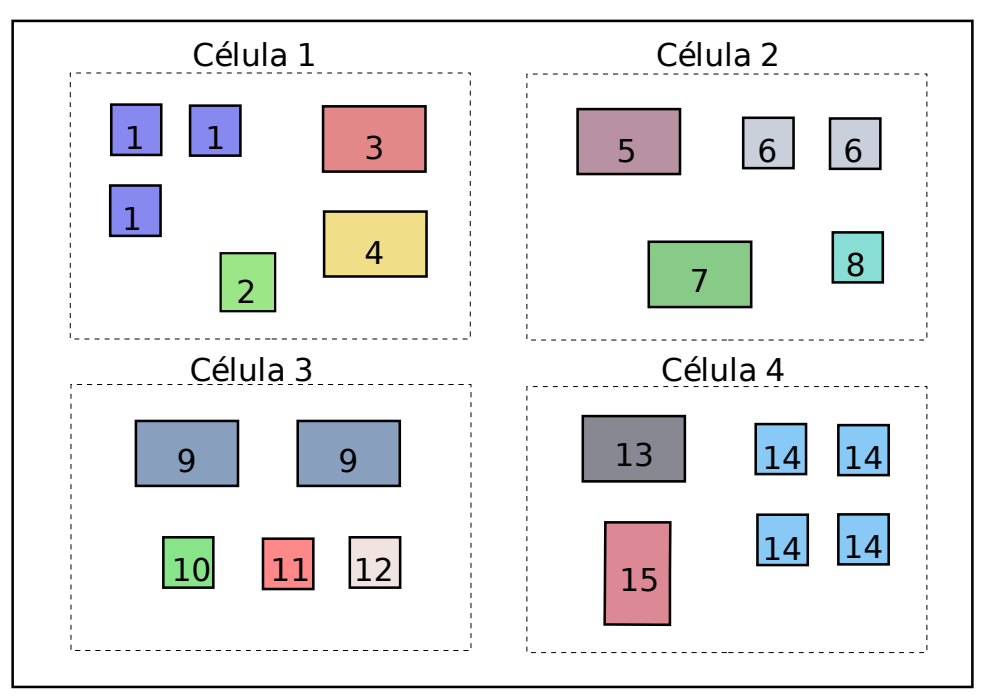

Figura 7. Réplicas de máquinas do mesmo tipo são alocadas na mesma célula 


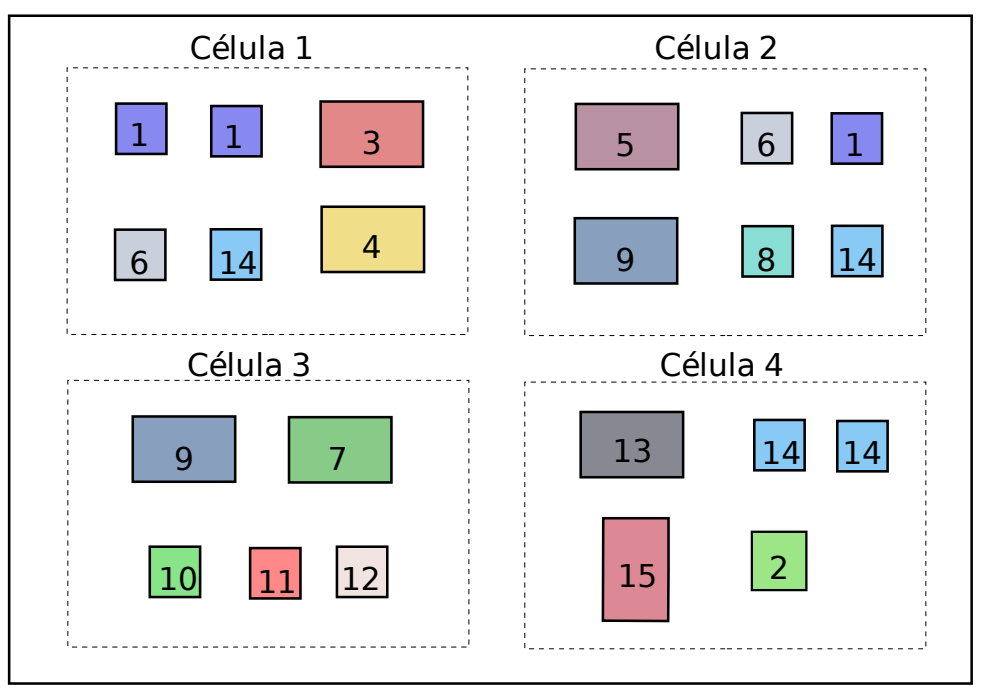

Figura 8. Réplicas de máquinas do mesmo tipo são distribuídas em células diferentes

Formação de famílias de peças e alocação das peças às células

$\mathrm{Na}$ abordagem tradicional do problema de formação de células, na qual se consideram apenas os tipos de máquinas, e não o número de réplicas de um mesmo tipo, pode-se estabelecer uma relação unívoca entre famílias de produtos e células. Ou seja, dado o conjunto de células, cada produto pode ser alocado a apenas uma célula, e a família a ser fabricada é a reunião de todos os produtos alocados àquela célula.

Entretanto, quando réplicas são distribuídas em células diferentes, pode haver mais de uma célula à qual uma peça pode ser alocada. Como idealmente a peça deveria ser completamente processada dentro de uma célula, escolhe-se aquela célula que seja capaz de executar o maior número de operações requeridas pela peça. No entanto, durante a operação diária do sistema de manufatura, a peça pode ter operações realizadas em outras células, de acordo com as circunstâncias operacionais. 
A Figura 9 exibe uma peça e sua seqüência de fabricação. Como a célula 1 é capaz de realizar mais operações que a célula 2 , a peça é alocada àquela. Quando há empate entre células, pode-se alocar a peça à célula que possui o menor número de peças já alocadas, ou àquela que tenha a menor carga de trabalho de acordo com as demandas das peças.

Seqüência de fabricação:

$$
1-3-4-14-5
$$
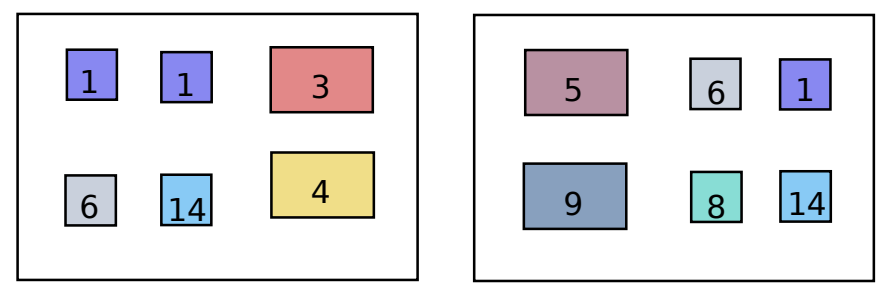

Célula 1: 4 operações Célula 2: 3 operações

Figura 9. A peça é alocada à célula 1

\subsection{Considerações finais}

Neste capítulo apresentaram-se o conceito de manufatura celular e algumas técnicas utilizadas para o projeto de células de manufatura. Também foram apresentadas a tipologia de sistemas de manufatura celular, algumas medidas de desempenho utilizadas em projetos de sistemas celulares e o problema de formação de células com réplicas de máquinas.

O capítulo 3 discorre sobre os algoritmos genéticos e sua aplicação a problemas em manufatura, particularmente os problemas de formação de células de produção. 


\section{ALGORITMOS GENÉTICOS}

\subsection{Introdução: inspiração biológica}

Algoritmos genéticos (AGs) são inspirados no princípio da evolução natural descrita por Charles Darwin em seu livro "A Origem das Espécies". Darwin, após a observação de várias espécies em habitats diferentes, chegou à conclusão de que os seres vivos não surgiram todos ao mesmo tempo, com suas características definidas. Contrariando a visão teológica da época, Darwin argumentou que havia evidências suficientes para afirmar que os seres vivos tinham passado por um processo de evolução. Ou seja, durante milhares de séculos os seres vivos diferenciaram-se em resposta a mudanças no ambiente, de tal forma que se adaptassem a novas condições.

A força motriz desse processo evolutivo é o que Darwin chamou de "seleção natural". Esse mecanismo funciona por meio da disputa entre indivíduos da mesma espécie e entre espécies diferentes. Em um ambiente dinâmico e com recursos naturais escassos, indivíduos dotados de características vantajosas teriam maior capacidade de obter recursos e, por conseguinte, sobreviver.

Darwin acreditava que as características eram transferidas para as gerações posteriores por meio da reprodução. No entanto, não conseguiu imaginar como as modificações nos organismos ocorriam. Após alguns anos, pesquisadores conseguiram identificar o fenômeno da mutação espontânea, por meio da qual os seres vivos adquirem modificações aleatórias em seus organismos. Caso a característica recém-adquirida conferisse alguma vantagem competitiva, tais indivíduos teriam maiores chances de conseguir alimento e se reproduzir, enquanto 
indivíduos menos adequados seriam gradativamente extintos.

\subsection{Complexidade computacional e otimização}

Em Engenharia, e muitas vezes também em computação, existe 0 interesse em obter soluções ótimas para problemas reais. Problemas reais são normalmente caraterizados por sua larga escala e complexidade, os quais impõem grandes desafios às técnicas computacionais de otimização. Um dos principais desafios é a complexidade computacional de tais problemas.

Em geral entende-se que o tempo que se leva para resolver um problema é uma boa medida de sua dificuldade e complexidade. Em Teoria da Computação, os problemas são normalmente classificados de acordo com seu grau de dificuldade.

Por exemplo, problemas que podem teoricamente ser resolvidos em uma máquina de Turing determinística em um tempo polinomialmente proporcional ao tamanho do problema são classificados como de "classe P" (deterministic Polinomial time). Uma máquina de Turing determinística é uma idealização matemática de um computador, e seu caráter determinístico significa que, dado um problema, a máquina realiza sempre a mesma seqüência de passos até chegar à solução.

Por outro lado, problemas que podem ser resolvidos em tempo polinomial em uma máquina de Turing não-determinística são considerados de "classe NP" (deterministic Non-Polinomial time). Máquinas de Turing não-determinísticas não seguem a mesma seqüência de passos quando submetidas a um mesmo problema, pois suas condições iniciais são modificadas cada vez que seu algoritmo é aplicado.

A classe NP engloba a classe P, como indicado na Figura 10. 


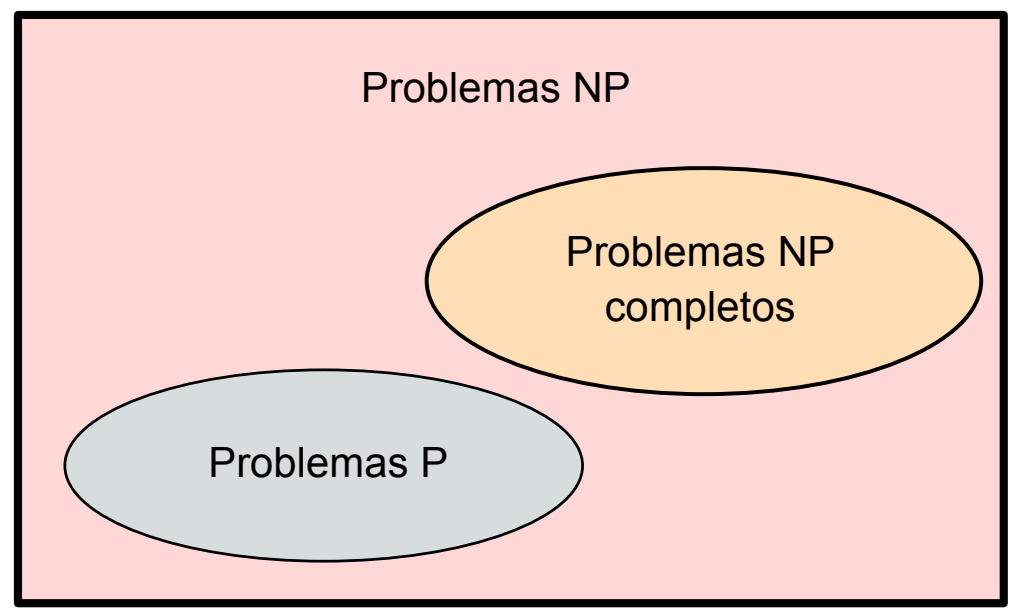

Figura 10. Classificação de problemas quanto à complexidade computacional (GAREY; JOHNSON, 1979)

Dentro da classe NP existe uma subclasse especial de problemas, chamados "NP-completos". Estes exibem uma propriedade formidável: qualquer problema NP pode ser reduzido a um problema NP-completo.

No entanto, os problemas NP-completos exibem outra propriedade singular, intimamente relacionada com sua complexidade computacional: todos os problemas NP-completos encontrados até o momento têm tempo de execução exponencialmente crescente com o tamanho do problema quando se tenta computálos em uma máquina de Turing determinística. Ou seja, à medida que se tentam resolver "instâncias" maiores de problemas NP-completos, atingem-se tempos de execução inviáveis mesmo para os supercomputadores mais modernos, já que os computadores reais se assemelham a uma máquina de Turing determinística. Problemas com complexidade computacional exponencial são referidos como "intratáveis".

Pensar na complexidade computacional dos problemas faz todo o sentido dentro da Teoria de Otimização, visto que muitos problemas de otimização são NP- 
completos (quando apropriadamente adaptados à definição formal de problema segundo a Teoria da Complexidade Computacional).

Entre os problemas de otimização que são NP-completos encontram-se muitos problemas de otimização combinatória, tais como: programação inteira com variáveis binárias, problemas de programação quadrática não-convexos, e o problema da mochila (PAPADIMITRIOU; STEIGLITZ, 1998). Logo, obter a solução ótima de instâncias grandes desses problemas (e a maioria dos problemas reais são de larga escala) é inviável.

\subsection{Heurísticas, meta-heurísticas e algoritmos genéticos}

Para contornar o problema da intratabilidade de muitos problemas, a alternativa é a obtenção de soluções sub-ótimas. Soluções sub-ótimas são de interesse em muitos problemas práticos, principalmente em Engenharia, visto que em muitas ocasiões a quantidade de soluções possíveis é muito grande.

Para a geração de soluções sub-ótimas, são desenvolvidos algoritmos especializados chamados de "heurísticas". Tais algoritmos têm por objetivo a utilização da informação existente a respeito do problema de forma que boas soluções sejam produzidas em um tempo aceitável. A desvantagem das heurísticas é a sua especialização, pois normalmente podem ser aplicadas somente ao problema ao qual se destinam.

Por outro lado, as meta-heurísticas são algoritmos genéricos e robustos que podem ser aplicados a qualquer problema com algumas modificações (GENDREAU; POTVIN, 2005). Algumas meta-heurísticas são inspiradas em fenômenos naturais, principalmente fenômenos físicos ou biológicos, com base na 
idéia de que a natureza, ao longo de milhões de anos, produziu soluções para vários de seus problemas, cujos princípios podem ser empregados para resolver problemas reais concebidos pelo homem.

Os AGs podem ser definidos como meta-heurísticas que se baseiam no princípio da seleção natural para evoluir uma população de soluções tentativas ao longo de uma seqüência de gerações após as quais espera-se a obtenção do ótimo global ou de soluções muito próximas deste. Por serem probabilísticos, não há garantia de que um AG encontrará a solução ótima. No entanto, a probabilidade do ótimo ser encontrado, à medida que o número de gerações tende ao infinito, é igual a 1 (GOLDBERG, 1989).

Além dos AGs, existem outras técnicas computacionais que se baseiam também em princípios evolutivos. Entre elas, podem-se citar a programação genética e as estratégias evolutivas. Essas técnicas em conjunto costumam ser chamadas de "algoritmos evolutivos", ou de "computação evolutiva". Bäck, Hammel e Schewefel (1997) fazem uma revisão das técnicas de Computação Evolutiva.

O pseudo-código de um AG é apresentando a seguir no Quadro 5.

Passo 0: Gere uma população inicial de indivíduos (soluções);

Passo 1: Para cada indivíduo, calcule a função objetivo e atribua como uma medida de adequação (fitness) do indivíduo ao ambiente;

Passo 2: Gere uma nova população a partir da aplicação de operadores de seleção e recombinação;

Passo 3: Aplique operadores de mutação à nova população gerada;

Passo 4: Se a condição de encerramento da execução foi atingida, pare. Caso contrário, retorne ao passo 1.

Quadro 5. Pseudo-código do algoritmo genético simples (GOLDBERG, 1989)

\subsubsection{Representação das soluções}


Para a aplicação de um AG a um problema, é preciso definir uma codificação para representar as soluções factíveis. Isso ocorre porque muitas vezes não é possível aplicar os operadores genéticos diretamente à representação natural do problema.

Inicialmente, os AGs admitiam apenas uma representação por cadeias de caracteres (strings) binárias (somente com caracteres 0 ou 1). Essa foi a forma utilizada por John Holland (GOLDBERG, 1989) nos seus primeiros experimentos com AGs. A Figura 11 exibe a representação de um problema da mochila por uma string binária. Nesse tipo de problema, cada posição da string representa um elemento a ser incluído na mochila. Se o elemento for incluído, a posição na string contém o valor 1 . Caso contrário, contém 0 .

\section{1}

$\begin{array}{ll}\text { Posição } 3 \text { na string } & \text { Elemento } 9 \text { é incluído } \\ \text { representa o elemento } 3 & \text { na mochila }\end{array}$

Figura 11. Representação por string binária de uma solução de um problema da mochila

No entanto, vários pesquisadores, a partir do fim dos anos 80 começaram a argumentar que, para muitos problemas, a representação por strings binárias era ineficiente em termos computacionais e de difícil implementação (MICHALEWICZ, 1998). Logo, começou-se a utilizar representações específicas que se adequassem à estrutura do problema, e principalmente às suas restrições. Vários tipos de representações passaram a ser usadas, como: strings de números inteiros, matrizes, 
multivetores, grafos, árvores, e representação de polish.

\subsubsection{Operadores genéticos}

Os AGs utilizam basicamente 3 tipos de operadores: seleção, cruzamento e mutação. A seguir serão apresentados alguns exemplos de cada um dos tipos de operadores.

Operador de seleção

O operador de seleção atua sobre a população como um todo, e seu objetivo é selecionar indivíduos bem adaptados, para a recombinação e geração de novos indivíduos. Esse operador em geral apresenta características de uma amostragem probabilística viciada a favor dos indivíduos com medidas de fitness maiores.

Entre os operadores de seleção mais usados estão o mecanismo da roleta e a seleção por torneio.

No mecanismo da roleta, cada indivíduo recebe um valor de probabilidade proporcional ao seu fitness. Cada probabilidade equivale a um subintervalo de uma roleta imaginária. Sorteiam-se então números entre 0 e 1 por meio de um gerador de números aleatórios, e para cada número sorteado verifica-se a qual intervalo da roleta o número se refere. O indivíduo correspondente a tal intervalo é então selecionado para fazer a recombinação com outro indivíduo também selecionado, gerando assim dois "filhos", os quais se integrarão à nova população. A Figura 12 exibe o funcionamento do mecanismo da roleta. 


\begin{tabular}{l|l|l|}
\hline Indivíduo & Fitness & $\begin{array}{l}\text { Fitness } \\
\text { percentual }\end{array}$ \\
\hline 1 & 30 & 0,30 \\
\hline 2 & 5 & 0,05 \\
\hline 3 & 15 & 0,15 \\
\hline 4 & 15 & 0,15 \\
\hline 5 & 15 & 0,15 \\
\hline 6 & 20 & 0,20 \\
\hline Total & 100 & 1 \\
\hline
\end{tabular}

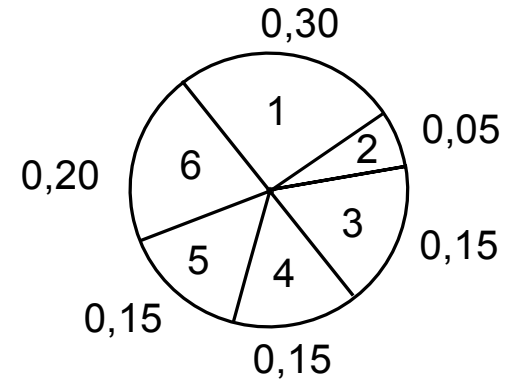

Figura 12. Ilustração do mecanismo da roleta

Outro mecanismo comum é o torneio. Neste, indivíduos são sorteados da população com igual probabilidade em 2 ou mais grupos. $\mathrm{O}$ indivíduo de maior fitness no grupo é então selecionado para fazer o cruzamento. O procedimento é repetido até que toda a nova população tenha sido gerada. $\mathrm{O}$ operador de torneio pode ser combinado com o mecanismo da roleta.

Operador de cruzamento

Este operador atua binariamente e é responsável pela troca de informação entre os indivíduos na população. A idéia subjacente é a de que melhores soluções podem emergir a partir da recombinação de partes de boas soluções. Este conceito está intimamente relacionado à troca de material genético nos seres vivos quando ocorre a reprodução e a geração da prole.

Este operador é de suma importância em termos computacionais, pois ele é o principal responsável pela exploração paralela do espaço de busca. Sua escolha deve ser feita com muito cuidado, de acordo com as características do problema 
(contínuo/discreto, perfil da função objetivo) e com a representação das soluções.

A Figura 13 exibe a aplicação de um operador de cruzamento a um par de soluções representadas como cadeias de caracteres (strings) binárias (somente com caracteres 0 ou 1 ).

\section{Pai $1 \quad 111 \mid 1111111$ \\ Pai 20000000000 \\ Cruzamento \\ Filho 10001111111 \\ Filho 21110000000}

Figura 13. Operador de cruzamento

Operador de mutação

O operador de mutação, em AGs, tem as funções de evitar que o problema fique estacionado em ótimos locais e de inserir novos indivíduos na população. Normalmente, este operador é implementado como a modificação aleatória de um bit na string binária, ou a inversão de bits. Cada vez que um indivíduo novo é gerado por cruzamento (ou na população inicial), é feito o teste se este indivíduo deve ou não sofrer mutação. O teste é positivo com certa probabilidade $\mathrm{p}$, a qual é um parâmetro do algoritmo fornecido pelo pesquisador. Valores típicos para a probabilidade de mutação residem por volta de 0,05, visto que uma probabilidade alta pode prejudicar consideravelmente a busca devido à alta 
taxa de destruição de padrões já encontrados (GOLDBERG, 1989).

A Figura 14 exemplifica um operador de mutação do tipo bitflip (alteração de bit) atuando em uma string binária.

\section{Indivíduo original $\quad 1111111111$ \\ Indivíduo mutado 1111101111}

Figura 14. Exemplo de operador de mutação

\subsubsection{Tratamento de restrições}

AGs são essencialmente voltados à otimização sem restrições, visto que restrições envolvem informação específica, e AGs não contêm pressuposto algum quanto à estrutura do problema. Portanto, procedimentos adicionais ad hoc devem ser implementados para que o AG seja capaz de explorar o espaço de soluções factíveis. Nos tópicos seguintes serão descritas algumas técnicas propostas.

\section{Funções de penalidade}

Uma abordagem de problemas com restrições muito popular é o uso de funções de penalidade. A idéia é atribuir uma penalidade a uma solução não-factível de forma que tais soluções são gradativamente excluídas durante o processo evolutivo (YENIAY, 2005).

O valor da penalidade pode ser constante ou variar segundo o grau de violação de uma ou mais restrições. Também existe a "pena de morte", em que soluções não-factíveis são sumariamente excluídas da população tão logo são 
geradas.

A equação (9) exibe uma função de penalidade do tipo aditiva, em que um valor maior ou igual a zero é adicionado à função-objetivo, resultando no valor de fitness do indivíduo.

$$
\mathrm{F}(\mathrm{x})=\mathrm{f}(\mathrm{x})+\mathrm{p}(\mathrm{x})
$$

Em que:

$\mathrm{F}(\mathrm{x})$ - Função de fitness;

$\mathrm{f}(\mathrm{x})$ - Função-objetivo;

$\mathrm{p}(\mathrm{x})$ - Função de penalidade.

Procedimentos de reparo (ou correção de não-factibilidade)

Reparar uma solução que viola alguma restrição é uma alternativa ao uso de funções de penalidade. Nessa abordagem, uma solução não-factível é submetida a um procedimento de correção, o qual modifica diretamente a solução, tornando-a factível. Nas palavras de Ahn (2006, p. 13), "the repair strategy is always advisable unless developing a repair function is an arduous task or the designed function is computationally too expensive by far."

\subsection{Aplicação de algoritmos genéticos ao projeto de sistemas de manufatura}

7 A estratégia de reparo é sempre recomendável, a menos que desenvolver uma função de reparo seja uma tarefa árdua ou a função desenvolvida seja computacionalmente exigente. (Tradução própria) 
Muitos aspectos do projeto de sistemas de manufatura, quando modelados matematicamente, exibem grande complexidade computacional. Devido a isso, é comum recorrer-se a heurísticas e meta-heurísticas.

Particularmente, os AGs têm sido aplicados com muito sucesso a vários problemas associados a sistemas de manufatura. Um dos primeiros pesquisadores a aplicá-los com resultados promissores foi Tam (1992). Em seu artigo, o autor aplica um AG com representação em árvore ao problema de projeto de arranjos físicos funcionais com restrições geométricas.

Venugopal e Narendran (1992) abordaram o problema de formação de células de produção, o qual é central no projeto de sistemas de manufatura celular. Em sua implementação, usaram um vetor de números inteiros, no qual a posição do número inteiro indica a máquina, e o número associado à posição significa a célula à qual a máquina está alocada. No estudo, utilizaram duas funções objetivo: minimização da movimentação intercelular de peças, e a minimização da variação de carga entre as células.

Tate e Smith (1995) aplicaram um AG ao problema quadrático de alocação(quadratic assignment problem - QAP), conhecido por ser da classe NPdifícil. Em suas experimentações, utilizaram uma representação em lista, na qual cada posição na lista significa um local disponível e o caractere alfanumérico associado àquela posição significa o departamento ou máquina alocados. Os autores concluíram que a solução por AGs, na maioria dos problemas testados, encontrou a solução ótima.

Mavridou e Pardalos (1997) fizeram uma revisão das aplicações de AGs e da meta-heurística têmpora simulada (simulated anealling) a problemas de arranjos 
físicos. Em suas considerações finais, afirmaram que ambas as heurísticas têm bons resultados, e são muito propícias para implementação em arquiteturas computacionais paralelas.

Rao, Pham e Gu (1999) propuseram uma metodologia para o projeto de sistemas de manufatura celular, a qual é apoiada por uma ferramenta computacional que integra um $A G$ com o software de desenho técnico AutoCAD. Os autores aplicaram a metodologia ao rearranjo de uma fábrica do setor metal-mecânico, e validaram o arranjo produzido com um modelo de simulação de eventos discretos. Ao final do projeto, melhorias consideráveis foram observadas.

Solimanpur, Vrat e Shankar (2004) propuseram um modelo de programação inteira multi-objetivo para o projeto de sistemas celulares com células independentes. Para solucionar o modelo, derivaram um algoritmo genético híbrido baseado no algoritmo VEGA - Vector Evaluated Genetic Algorithm - e em um tipo de delineamento de experimentos uniforme. Os autores aplicaram seu algoritmo a quatro problemas da literatura. Em pelo menos um problema o algoritmo encontrou melhores soluções que as soluções originais.

Gonçalves Filho e Tiberti (2006) desenvolveram um algoritmo genético de grupo para a solução do problema de formação de células bi-objetivo. Nele, uma nova representação das soluções e novos operadores foram apresentados. O algoritmo foi aplicado a dados da literatura, sendo capaz de encontrar boas soluções.

Dimopoulos (2007) descreveu um procedimento para solução do problema de geração de células de produção multiobjetivo. O autor utilizou programação genética para aproximar coeficientes de similaridade adequados ao problema, SLC para gerar as famílias de peças, e o NSGA para fazer a busca por 
soluções eficientes. O algoritmo foi aplicado a dados da literatura e a um problema real, obtendo aproximações da fronteira de Pareto.

\subsection{Considerações finais}

Neste capítulo foram apresentados os algoritmos genéticos e sua aplicação a problemas em manufatura. Enfatizou-se sua importância para a solução de problemas de otimização difíceis, principalmente aqueles classificados nas classes de problemas NP-completos e problemas NP-difíceis de acordo com a Teoria da Complexidade Computacional.

Muitos problemas em manufatura são intratáveis, e por isso as heurísticas e meta-heurísticas têm papel decisivo na solução desses problemas.

No próximo capítulo será apresentada a técnica de otimização multiobjetivo, que permite a inclusão simultânea de muitas funções-objetivo ou medidas de desempenho na formulação de um problema de otimização. Como será visto, os algoritmos genéticos têm gerado bons resultados em abordagens multiobjetivas. 


\section{OTIMIZAÇÃO MULTIOBJETIVO}

Em Matemática, o ótimo de uma função $\mathrm{f}(\mathbf{x})$ é um vetor $\mathbf{x}^{*}$ em um conjunto A para o qual $\mathrm{f}\left(\mathbf{x}^{*}\right)$ é o valor máximo ou mínimo da função. Neste caso, a função $\mathrm{f}(\mathbf{x})$ pode representar uma medida de desempenho ou uma característica de um problema a qual se deseja otimizar. Portanto, tomando a terminologia da Pesquisa Operacional, dá-se o nome a essas funções de "funções-objetivo".

O propósito da otimização multiobjetivo é obter o valor $\mathbf{x}^{*}$ que otimiza simultaneamente um vetor de funções $F=\left(f_{1}(\mathbf{x}), f_{2}(\mathbf{x}), \ldots, f_{m}(\mathbf{x})\right)$ (COELLO; LAMONT; VELDHUIZEN, 2007). No entanto, neste caso, raramente existe um vetor $\mathbf{x}^{*}$ que otimiza todas as funções de interesse simultaneamente. A noção de otimalidade, no caso de múltiplos objetivos, deve ser redefinida.

Entre as diversas formas que se pode definir uma solução ótima para problemas multiobjetivos, uma definição muito conveniente e muito utilizada foi sugerida pelo economista italiano Vilfredo Pareto, no fim do século XIX. Pareto argumentou que uma solução ótima para um problema multiobjetivo deveria apresentar um equilíbrio entre as diversas funções de interesse, de tal forma que a tentativa de melhorar o valor de uma função isoladamente implicaria na piora de uma ou mais das outras funções. Pareto imaginou esse equilíbrio em relação à economia como um todo, o que passou a ser chamado de "ótimo de Pareto" ou "equilíbrio de Pareto". 
Nas palavras de Ehrgott (1999, p.3):

Historically, the first reference to address such situations of conflicting objectives is usually attributed to Pareto (1896) who wrote (the quote is from the 1906 English edition of his book, emphasis added by the author): We will say that the members of a collectivity enjoy maximum ophelimity in a certain position when it is impossible to find a way of moving from that position very slightly in such a manner that the ophelimity enjoyed by each of the individuals of that collectivity increases or decreases. That is to say, any small displacement in departing from that position necessarily has the effect of increasing the ophelimity. ${ }^{8}$

Outra característica diferenciadora das soluções para problemas multiobjetivos é que elas, na maior parte das vezes, não são únicas. Ou seja, é comum se falar em "conjunto ótimo de Pareto", em vez de apenas “ótimo de Pareto". Cada uma das soluções do conjunto ótimo de Pareto representam uma possível compensação (trade-off) ótimo entre as diversas funções-objetivo.

\subsection{Formulação matemática de um problema multiobjetivo}

Um problema multiobjetivo é composto por um conjunto de soluções factíveis, comumente chamado de espaço de busca; um conjunto de restrições, que delimitam o espaço de busca; e uma função vetorial F, cujas componentes são funções-objetivo. A função $F$ mapeia o conjunto de soluções "A" n-dimensional em um conjunto imagem "B" m-dimensional - também chamado de espaço objetivo. Em notação matemática: $\mathrm{F}: \mathrm{A}^{\mathrm{n}} \rightarrow \mathrm{B}^{\mathrm{m}}$. A Figura 15 exibe um mapeamento de um espaço de busca no $R^{2}$ em um espaço-objetivo também no $R^{2}$.

As equações (10), (11), (12) e (13) formulam matematicamente o

8 Historicamente, a primeira referência a abordar situações de objetivos conflitantes é geralmente atribuída a Pareto (1896), que escreveu (a referência é da edição de seu livro de 1906): Pode-se afirmar que membros de uma coletividade desfrutam de máxima satisfação econômica em certa posição quando é impossível encontrar uma maneira de se mover levemente dessa posição e ao mesmo tempo aumentar ou diminuir a satisfação econômica de cada indivíduo. Isto é, um pequeno deslocamento a partir de tal posição tem necessariamente o efeito de aumentar a satisfação econômica. (tradução própria) 
problema geral de otimização multiobjetivo.

$$
\min / \max \quad \mathrm{f}_{\mathrm{i}}(\mathbf{x}) \quad \text { for } \mathrm{i} \in\{1,2, \ldots, \mathrm{n}\}
$$

sujeito a

$$
\begin{array}{rlr}
\mathrm{g}_{\mathrm{j}}(\mathbf{x}) & \leq \mathrm{b}_{\mathrm{j}} \quad \forall \mathrm{j} \\
\mathrm{h}_{\mathrm{k}}(\mathbf{x})=\mathrm{c}_{\mathrm{k}} \quad \forall \mathrm{k} \\
\mathbf{x} \in \mathrm{A}
\end{array}
$$

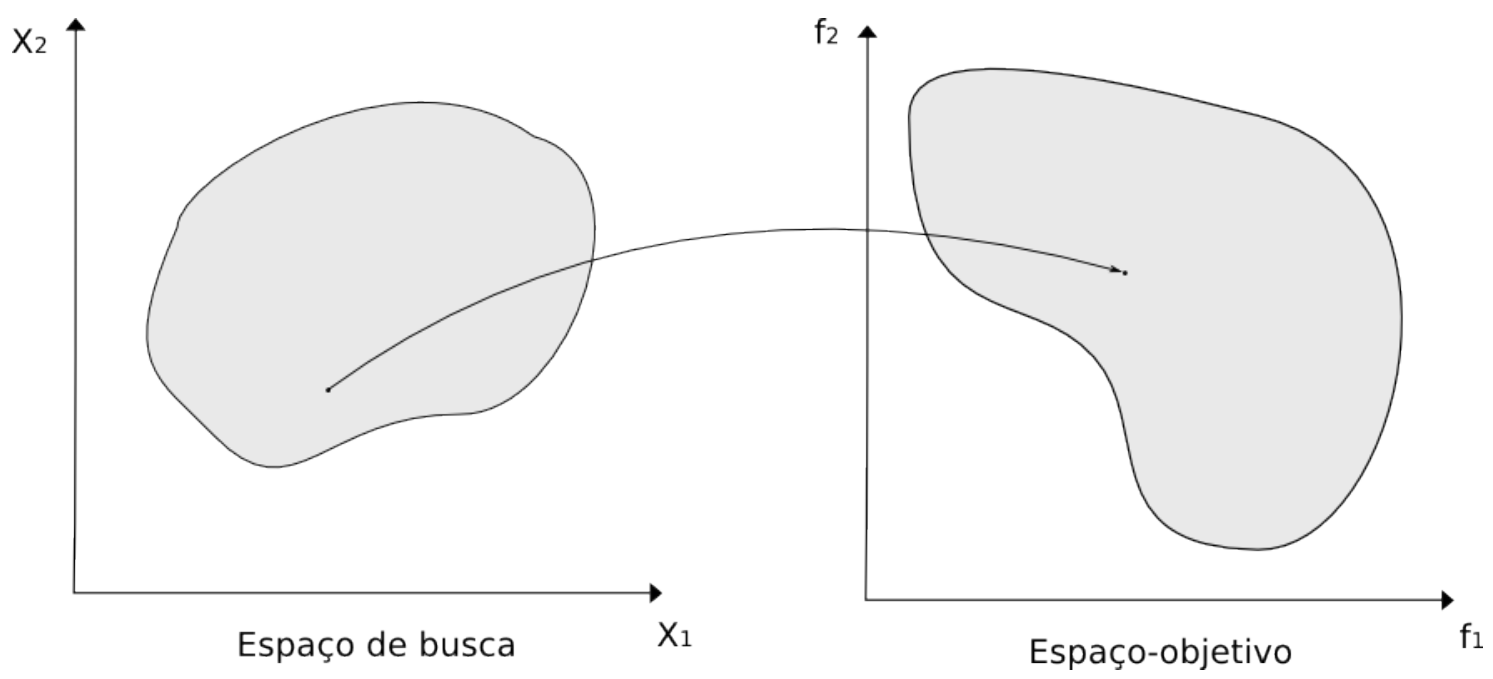

Figura 15. Mapeamento de um espaço de busca no R2 em um espaço-objetivo também no R2

\subsection{Algumas definições importantes}

\subsubsection{Dominância de Pareto}

Para o desenvolvimento de algoritmos capazes de encontrar o conjunto ótimo de Pareto, é necessária a definição de uma relação binária chamada "dominância de Pareto": "Uma solução $\mathbf{x}_{\mathrm{a}}$ domina outra solução $\mathbf{x}_{\mathrm{b}}$ se os valores 
funcionais em $\mathbf{x}_{\mathrm{a}}$ forem maiores ou iguais aos valores funcionais em $\mathbf{x}_{\mathrm{b}}$, e para pelo menos uma das funções-objetivo, o valor funcional em $\mathbf{x}_{a}$ é estritamente maior que 0 valor funcional em $\mathbf{x}_{\mathrm{b}} . "$ (DEB, 2001).

Em outras palavras, uma solução $\mathbf{x}_{\mathbf{a}}$ domina outra solução $\mathbf{x}_{\mathbf{b}}$ se $f_{i}\left(\mathbf{x}_{\mathbf{a}}\right) \geq f_{i}\left(\mathbf{x}_{\mathbf{b}}\right)$ para $\mathrm{i}=1$..M e existe pelo menos um i* para o qual $\mathrm{f}_{\mathrm{i}^{*}}\left(\mathbf{x}_{\mathbf{a}}\right)>\mathrm{f}_{\mathrm{i}^{*}}\left(\mathbf{x}_{\mathbf{b}}\right)$. Neste caso, admite-se maximização das funções. Quando se deseja minimização, basta substituir os sinais de maior e igual por sinais de menor e igual.

Matematicamente:

$$
\begin{array}{lll}
\mathbf{x}_{\mathrm{a}} \triangleleft \mathbf{x}_{\mathbf{b}} & \text { se e somente se } & \mathrm{f}_{\mathrm{i}}\left(\mathbf{x}_{\mathbf{a}}\right) \geq \mathrm{f}_{\mathrm{i}}\left(\mathbf{x}_{\mathbf{b}}\right) \quad \forall \mathrm{i} \\
\mathrm{e} \exists \mathrm{i}^{*} & \text { para o qual } & \mathrm{f}_{\mathrm{i}^{\circ}}\left(\mathbf{x}_{\mathbf{a}}\right)>\mathrm{f}_{\mathrm{i}^{*}}\left(\mathbf{x}_{\mathbf{b}}\right)
\end{array}
$$

Em que o símbolo 4 significa "domina".

Quando se comparam 2 soluções $\mathbf{x}_{a}$ e $\mathbf{y}_{\mathrm{b}}$ para se estabelecer se uma delas domina a outra, 3 casos podem ocorrer:

i. Solução $\mathbf{x}_{\mathrm{a}}$ domina solução $\mathbf{x}_{\mathrm{b}}$;

ii. Solução $\mathbf{x}_{b}$ domina solução $\mathbf{x}_{a}$;

iii. Nenhuma das 2 soluções domina a outra.

O conceito de dominância de Pareto pode ser mais facilmente visualizado por uma ilustração, como na Figura 16. No exemplo mostrado, pressupõe-se maximização das funções $f_{1}$ e $f_{2}$. Se uma solução i está contida no retângulo de uma solução j, significa que i é dominada por j. Se nenhum dos retângulos de i e j contém o outro, significa que i e j são ambas não-dominadas.

Pode-se observar que A é dominada por C, E e F; B é dominada por C, $D$, E e F; C é dominada por E; D é dominada por E e F; por fim, E e F não são 
dominadas por nenhuma solução. Comparando-se B e C, nota-se que ambas possuem o mesmo valor em $\mathrm{f}_{1}$, mas $\mathrm{C}$ possui valor maior em $\mathrm{f}_{2}$, dominando $\mathrm{B}$.

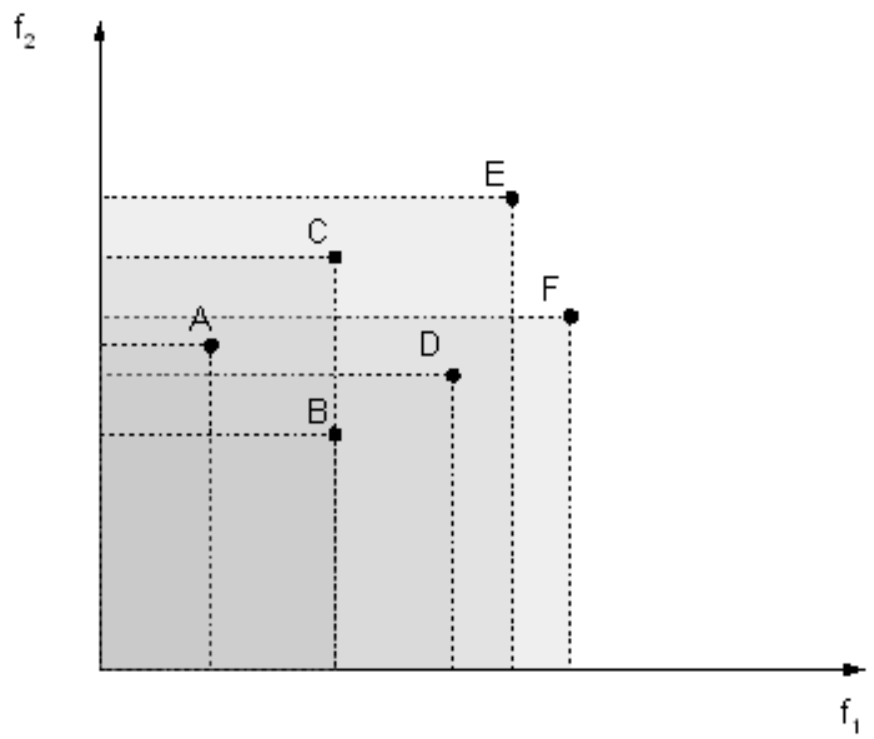

Figura 16. Conceito de dominância de Pareto

\subsubsection{Conjuntos não-dominados}

Dado um conjunto de soluções $A$, existe um subconjunto $S$ de soluções em A tal que todas as soluções são não-dominadas. Ou seja, para qualquer par $\mathbf{x}_{\mathrm{a}} \mathrm{e}$ $\mathbf{y}_{\mathrm{b}}$ em S, $\mathbf{x}_{\mathrm{a}} \triangleleft \mathbf{x}_{\mathrm{b}}$ e $\mathbf{x}_{\mathrm{b}} \ \mathbf{x}_{\mathrm{a}}$ são ambas falsas.

O conceito de conjunto não-dominado é de suma importância para o desenvolvimento de algoritmos de otimização multiobjetivo, pois o subconjunto de todas as soluções não-dominadas do espaço de busca representa o conjunto ótimo de Pareto. Algoritmos multiobjetivos baseados no conceito de otimalidade de Pareto compõem gradativamente o conjunto de soluções ótimas por meio da busca de soluções não-dominadas e da formação temporária de conjuntos não-dominados. 
4.2.3 Conjunto ótimo de Pareto e fronteira ótima de Pareto

Dá-se o nome de fronteira ótima de Pareto ao conjunto imagem, contido no espaço objetivo, resultante da aplicação da função vetorial F (cujas componentes são as funções-objetivo) ao conjunto ótimo de Pareto, o qual é o conjunto de todas as soluções não-dominadas pertencentes ao espaço de decisão (também chamado de espaço de busca) (DEB, 2001). O título "fronteira" faz alusão ao fato de que em geral os valores das soluções ótimas encontram-se nas fronteiras do espaço objetivo. A Figura 17 exibe uma fronteira de Pareto em duas dimensões.

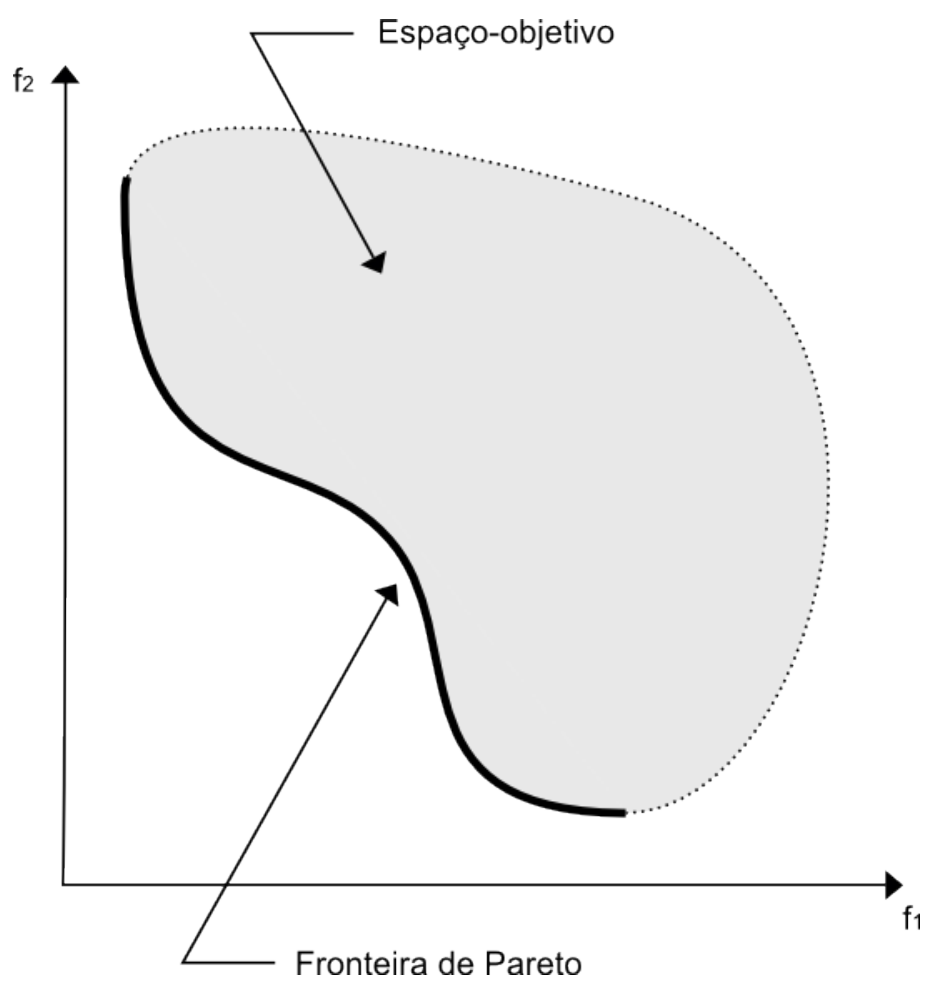

Figura 17. Fronteira de Pareto em 2 dimensões (DEB, 2001) 
A determinação da fronteira ótima de Pareto não é uma tarefa simples, visto que determinar se um único ponto faz parte do conjunto ótimo de Pareto é um problema NP-difícil mesmo para problemas com apenas 2 objetivos. (PAPADIMITRIOU; YANNAKAKIS apud CHINCHULUUN; PARDALOS, 2007).

\subsubsection{Vetor de objetivos ideal}

O vetor de objetivos ideal é um vetor cujas componentes são os valores ótimos de cada função-objetivo se cada uma delas for otimizada isoladamente. Ou seja, dado um problema multiobjetivo e seu vetor de funções $F(\mathbf{x})=\left(f_{1}(\mathbf{x}), f_{2}(\mathbf{x}), \ldots\right.$, $\left.\mathrm{f}_{\mathrm{n}}(\mathbf{x})\right)$, o vetor de objetivos ideal é $\mathbf{z}^{*}=\left(\mathrm{f}_{1}\left(\mathbf{x}^{*(1)}\right), \mathrm{f}_{2}\left(\mathbf{x}^{*(2)}\right), \ldots, \mathrm{f}_{\mathrm{n}}\left(\mathbf{x}^{*(\mathrm{n})}\right)\right)$, em que $\mathbf{x}^{*(\mathrm{i})}$ é o vetor-solução que otimiza a função $\mathrm{f}_{\mathrm{i}}(\mathbf{x})$ isoladamente.

A Figura 18 exibe o vetor de objetivos ideal.

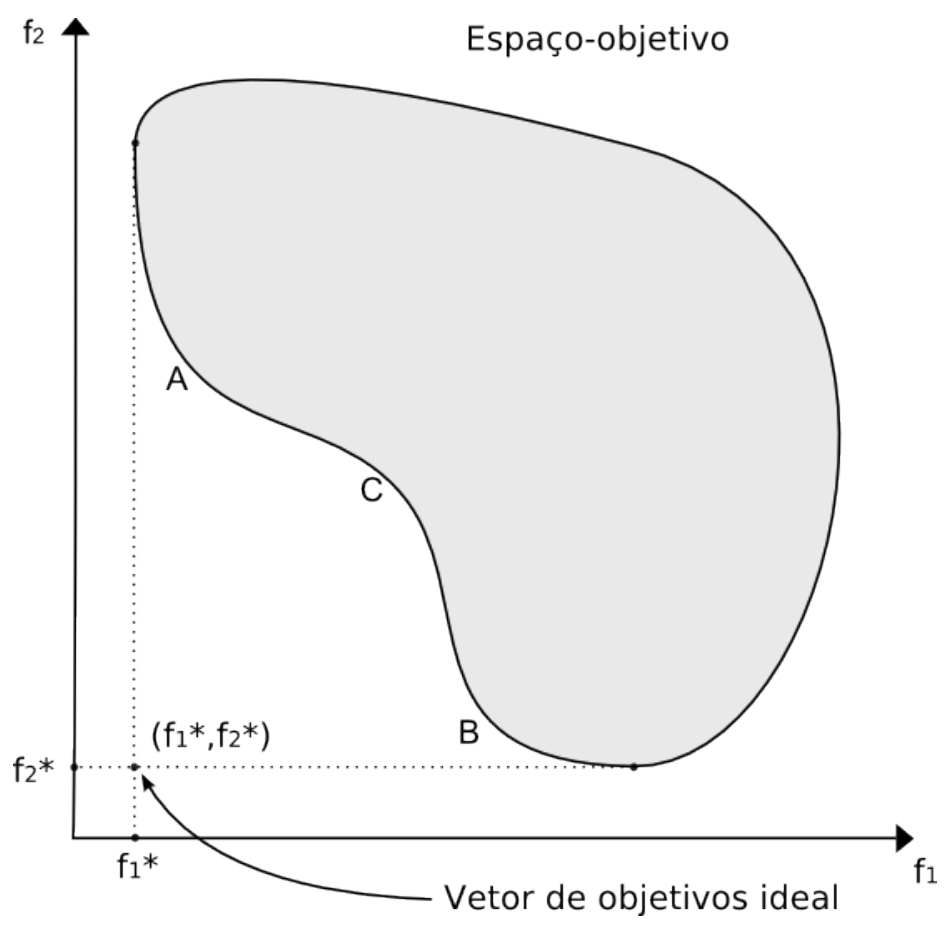

Figura 18. Vetor de objetivos ideal. No problema ilustrado, deseja-se minimizar $f_{1}$ e $f_{2}$ (DEB, 2001) 
4.3 Métodos clássicos para a solução de problemas de otimização multiobjetivo

Existem muitos métodos utilizados para a solução de problemas multiobjetivos. Em geral, são técnicas de Programação Matemática originalmente desenvolvidas para a solução de problemas uniobjetivos, e que foram adaptadas para abordar múltiplas funções-objetivo.

A abordagem natural para tal adaptação é agregar as funções-objetivo em apenas uma função "global". Nos tópicos seguintes são revisadas algumas dessas técnicas.

\subsubsection{Método da soma ponderada}

Esse método tem o funcionamento bastante simples, e resume-se a reduzir o problema multiobjetivo a um problema uniobjetivo por meio de uma soma ponderada das funções-objetivo. Dado um vetor de funções $\left(f_{1}(\mathbf{x}), f_{2}(\mathbf{x}), \ldots, f_{n}(\mathbf{x})\right)$, resolve-se o problema indicado nas equações (15), (16), (17), e (18).

$$
\min / \max \quad \mathrm{F}(\mathbf{x})=\mathrm{w}_{1} \mathrm{f}_{1}(\mathbf{x})+\mathrm{w}_{2} \mathrm{f}_{2}(\mathbf{x})+\ldots+\mathrm{w}_{\mathrm{i}} \mathrm{f}_{\mathrm{i}}(\mathbf{x})+\ldots+\mathrm{w}_{\mathrm{n}} \mathrm{f}_{\mathrm{n}}(\mathbf{x})
$$

sujeito a

$$
\begin{array}{cc}
\mathrm{g}_{\mathrm{i}}(\mathbf{x}) \leq 0 & \forall \mathrm{i} \\
\mathrm{h}_{\mathrm{j}}(\mathbf{x})=0 & \forall \mathrm{j} \\
\mathbf{x} \in \mathrm{A} &
\end{array}
$$

Dadas as características matemáticas da função-objetivo resultante e das restrições, métodos clássicos de otimização podem ser empregados, como: 
multiplicadores de Lagrange, algoritmo simplex, branch and bound, métodos baseados em vetor gradiente, heurísticas e meta-heurísticas.

Apesar de muito simples, o sucesso no uso do método da soma ponderada depende essencialmente da escolha de valores adequados para os pesos. Essa não é uma tarefa fácil, visto que as funções-objetivo podem ser incomensuráveis (têm unidades de medida diferentes), e os pesos refletem a importância de uma função em relação às outras. Logo, a escolha dos pesos reflete obrigatoriamente uma estrutura de preferência a priori, viesando a busca no espaço de soluções. Outras críticas recorrentes ao método refere-se à sua capacidade de gerar apenas uma solução Pareto-ótima por vez, e sua incapacidade em gerar o conjunto ótimo quando a fronteira de Pareto possui uma região não-convexa. Esse fato é melhor ilustrado na Figura 19. Nela é possível observar que a soma ponderada impõe uma estrutura linear ao processo de busca, impedindo a geração de soluções em regiões não-convexas da fronteira de Pareto.

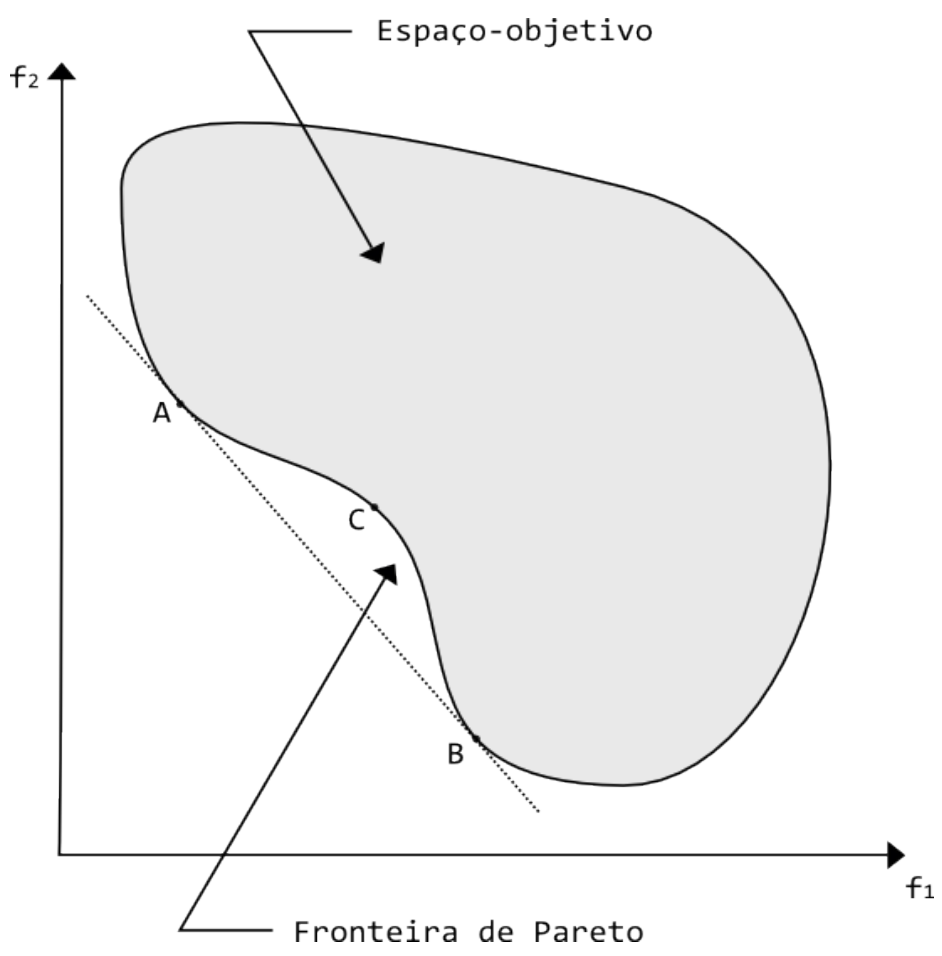

Figura 19. O método ponderado não consegue encontrar soluções em regiões não-convexas 
4.3.2 Métodos de métrica ponderada

Esses métodos têm o mesmo princípio do método da soma ponderada, ou seja, agregar as funções-objetivo em apenas uma função, mas tentam superar a dificuldade com problemas com regiões não-convexas no espaço de objetivos.

A idéia é substituir a soma ponderada por uma medida de distância do vetor de objetivos ao vetor de objetivos ideal. O problema é formalizado de acordo com as equações (19), (20), (21) e(22).

$$
\min / \max \quad \mathrm{l}_{\mathrm{p}}=\left(\sum_{\mathrm{i}}^{\mathrm{m}} \mathrm{w}_{\mathrm{i}} \mid \mathrm{f}_{\mathrm{i}}(\mathbf{x})-\mathbf{z}_{\mathrm{i}}^{\mathrm{p}}\right)^{1 / \mathrm{p}}
$$

sujeito a

$$
\begin{gathered}
\mathrm{g}_{\mathrm{j}}(\mathbf{x}) \leq 0 \quad \forall \mathrm{j} \\
\mathrm{h}_{\mathrm{k}}(\mathbf{x})=0 \quad \forall \mathrm{k} \\
\mathbf{x} \in \mathrm{A}
\end{gathered}
$$

Em que:

$1_{p}$ - Medida de distância;

$\mathrm{W}_{\mathrm{i}}$ - peso associado à função-objetivo $\mathrm{i}$;

$\mathrm{f}_{\mathrm{i}}(\mathrm{x})$ - função-objetivo i;

$\mathbf{z}_{\mathrm{i}}$ - vetor de objetivos ideal;

p - parâmetro que define a medida de distância utilizada. 
O parâmetro $p$ pode variar de $1 \mathrm{a} \infty$. Quando $p=1$, a função de agregação se reduz à soma ponderada; $p=2$ a métrica se torna a distância Euclidiana; e para $p$ $=\infty$ (ou p muito grande), a métrica se torna a distância de Tchebychev.

A Figura 20 ilustra o uso desse método, e sua capacidade de gerar soluções em regiões não-convexas.

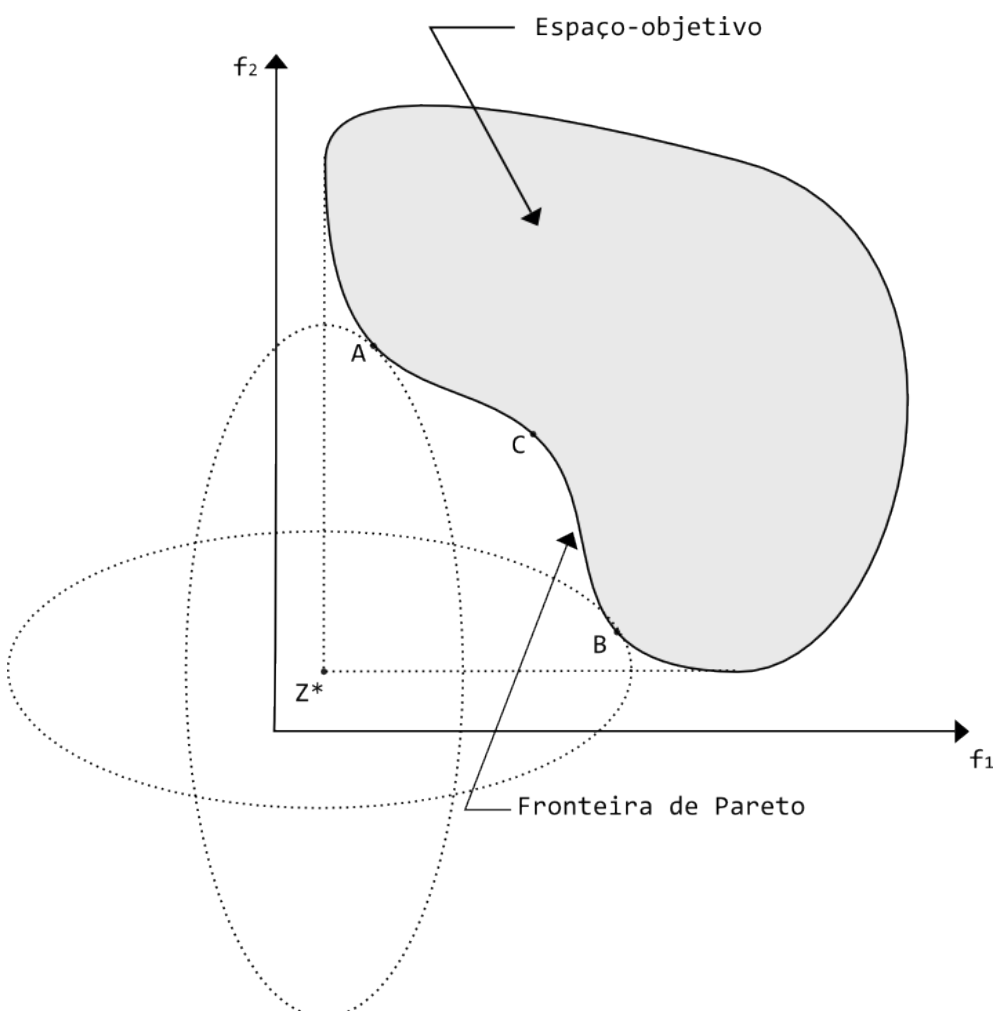

Figura 20. Exemplo do método por métrica utilizando a métrica Euclidiana $(p=2)$

Apesar de ser capaz de gerar soluções em regiões não-convexas, esse método ainda mantém algumas das limitações dos métodos de média ponderada, como a de escolha de pesos para as funções-objetivo, e a necessidade de várias aplicações do método com valores diferentes para os pesos com o objetivo de aproximar toda a fronteira de Pareto. 
4.3.3 Métodos de função de valor (ou de utilidade)

Esse métodos são semelhantes aos métodos de métrica ponderada, mas em vez de medidas de distância, usam o que se chama em Economia de "função de utilidade".

As funções de utilidade são funções dos objetivos do problema, e tentam captar a estrutura de preferência do tomador de decisão. São em geral não-lineares e convexas. Dado um vetor $F(\mathbf{x})=\left(f_{1}(\mathbf{x}), f_{2}(\mathbf{x}), \ldots ., f_{n}(\mathbf{x})\right)$ de funções-objetivo, uma função de utilidade é definida como $U(F(\mathbf{x}))=U\left(f_{1}(\mathbf{x}), f_{2}(\mathbf{x}), \ldots ., f_{n}(\mathbf{x})\right)$. A função $U(F(\mathbf{x}))$ é determinada de tal forma que valores maiores de utilidade sejam desejados. Logo, o problema de otimização multiobjetivo passa a ser definido como seguinte:

$$
\text { Maximizar } \quad \mathrm{U}(\mathrm{F}(\mathbf{x}))
$$

sujeito a

$$
\begin{array}{rll}
\mathrm{g}_{\mathrm{j}}(\mathbf{x}) \leq 0 & \forall \mathrm{j} \\
\mathrm{h}_{\mathrm{k}}(\mathbf{x})=0 & \forall \mathrm{k} \\
& & \\
\mathbf{x} & \in & \text { A }
\end{array}
$$

Em Economia, tais funções são muito comuns em Teoria Microeconômica, na qual as funções-objetivo são as quantidades de um conjunto de produtos, a função utilidade é uma função das quantidades de produtos, e o espaço de decisão é limitado pela restrição orçamentária do consumidor.

O método é capaz de gerar apenas uma solução na fronteira de Pareto, a 
qual seria preferível a todas as outras da fronteira, visto que a função de utilidade já contém informação quanto às preferências do tomador de decisão. A Figura 21 ilustra um exemplo.

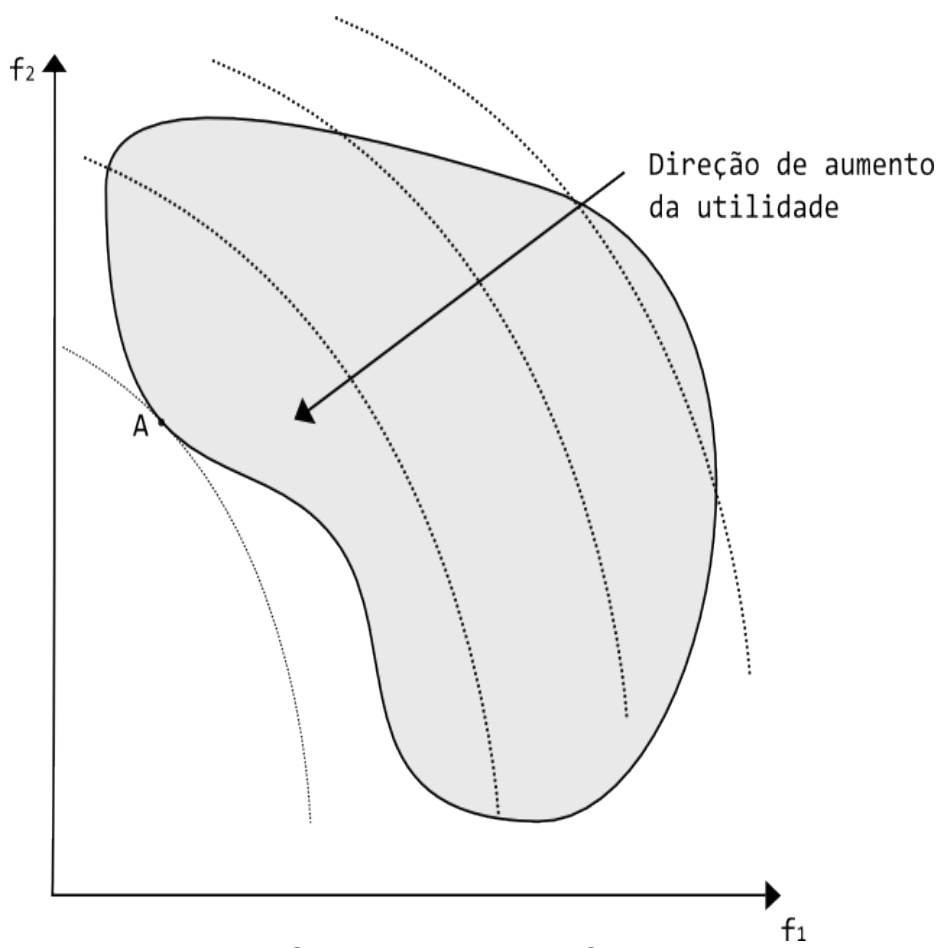

Figura 21. Curvas de nível da função utilidade

\subsection{Solução de problemas de otimização multiobjetivo por algoritmos evolucionários}

Algoritmos evolucionários, também chamados de algoritmos evolutivos e de algoritmos genéticos, como já descrito na seção 3, são meta-heurísticas inspiradas no princípio biológico da seleção natural e da evolução das espécies. Os algoritmos evolucionários têm sido aplicados a problemas de otimização com uma função-objetivo, mas a partir do fim dos anos 80 intensificou-se o interesse por aplicá-los a problemas de otimização multimodal e multiobjetivo (COELLO, 2006).

Os algoritmos evolucionários apresentam um conjunto de características favoráveis à sua aplicação a problemas de otimização multiobjetivo. Entre elas, 
destacam-se as seguintes:

- Uso de uma população de soluções: Problemas multiobjetivos apresentam um conjunto de soluções igualmente ótimas - o conjunto ótimo de Pareto - e a utilização de uma população de soluções permite a aproximação desse conjunto em apenas uma rodada do algoritmo;

- Aplicação a problemas não-convexos: Problemas que possuem não-convexidades na fronteira de Pareto impõem dificuldades a algumas técnicas clássicas, mas os algoritmos evolucionários lidam bem com esse tipo de problema;

- Fácil adaptação a problemas em diferentes domínios: Por serem meta-heurísticas, os mecanismos de busca dos algoritmos evolucionários não são específicos do problema em questão, requerendo apenas uma representação adequada das soluções e a implementação de operadores específicos;

- Flexibilidade quanto às funções-objetivo: Como não fazem suposições quanto aos tipos das funções e seu espaço de busca, os algoritmos evolucionários funcionam como caixas-pretas, requerendo apenas uma medida de adequação (fitness). Logo, podem ser aplicados a funções que não têm uma representação matemática explícita, como no caso em que se usam modelos de simulação para a avaliação das soluções.

Existem alguns algoritmos evolucionários para otimização multiobjetivo propostos na literatura. Entre eles se destacam o Strength Pareto Evolutionary 
Algorithm (SPEA), e o Non-dominated Sorting Genetic Algorithm versão 2 (NSGA II). Será detalhado apenas o NSGA II, visto que este algoritmo foi utilizado neste trabalho.

\subsubsection{Non-dominated Sorting Genetic Algorithm versão 2 - NSGA II}

O NSGA - II foi proposto por Deb et al. (2002) como aprimoramento do algoritmo NSGA desenvolvido pelos mesmos autores. É um algoritmo genético elitista, multiobjetivo, e possui uma complexidade temporal em pior caso de $\mathrm{O}\left(\mathrm{MN}^{2}\right)$, em que $\mathrm{M}$ é o número de funções-objetivo a serem simultaneamente otimizadas e $\mathrm{N}$ é o tamanho da população utilizada.

No Quadro 6 são descritos os passos do algoritmo NSGA - II, e na Figura 22 exibe-se esquematicamente o seu funcionamento. Nela, $P_{t}$ indica a população base na geração $t$, e $Q_{t}$ é a população derivada obtida por meio de operadores genéticos. $F_{i}$ denota o nível de dominância $\mathrm{i}$, e $\mathrm{P}_{\mathrm{t}+1}$ é a população resultante que representa agora a geração $t+1$.

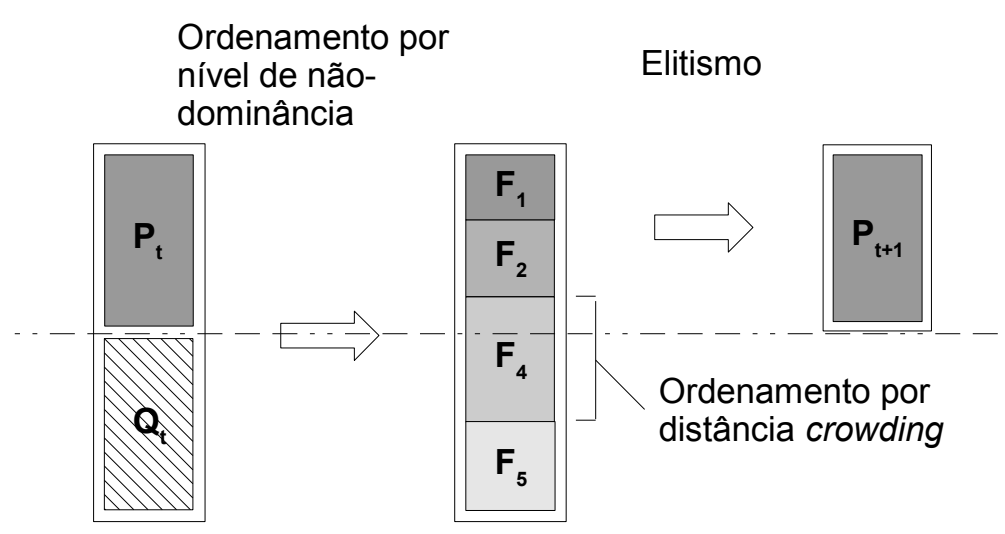

Figura 22. Esquema de funcionamento do algoritmo NSGA-II (DEB, 2001) 


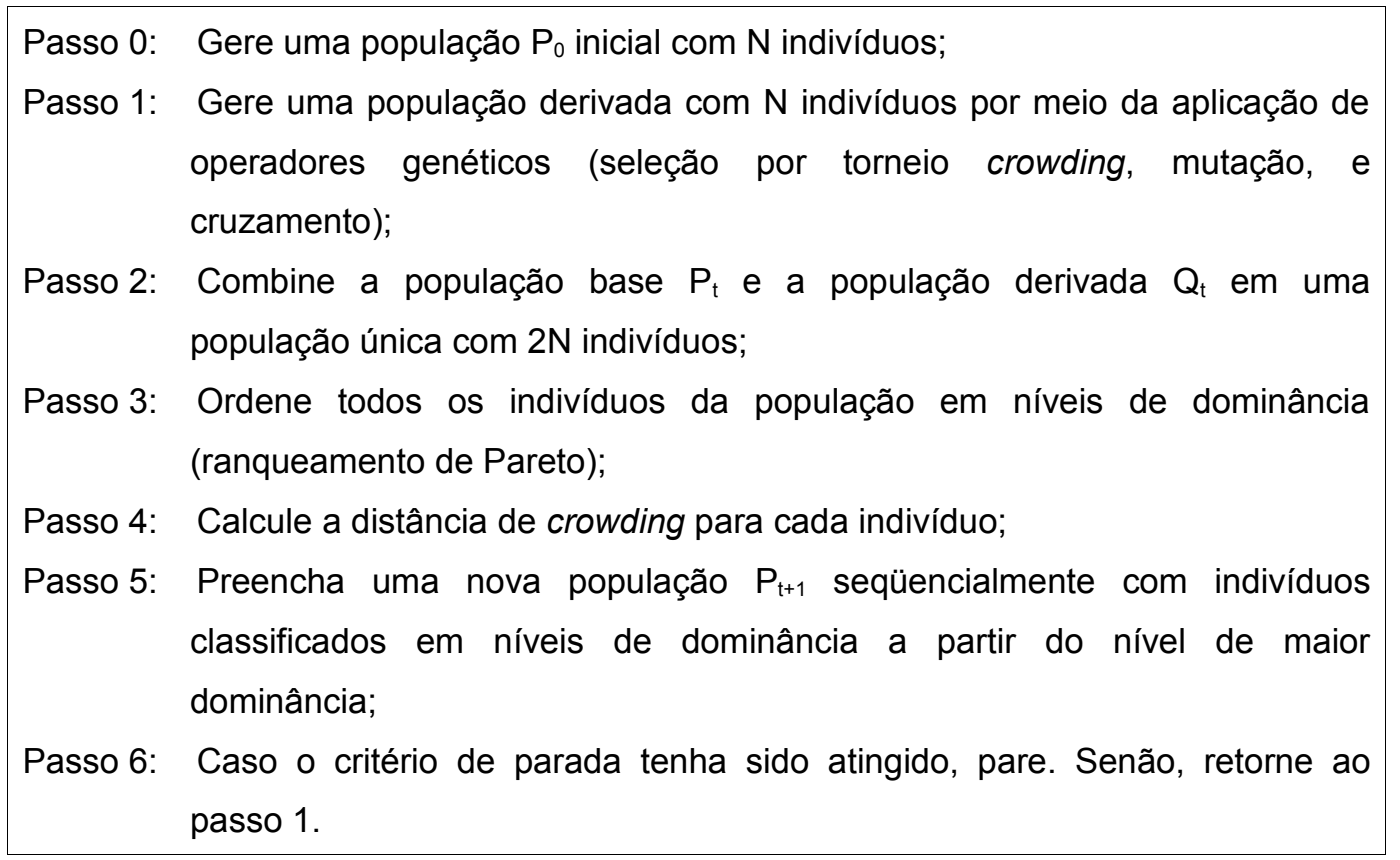

Quadro 6. Pseudo-código do algoritmo NSGA-II (DEB, 2001)

\subsubsection{Ordenamento por nível de não-dominância}

Dado um conjunto de soluções, é possível dividi-lo em subconjuntos de acordo com níveis de não-dominância. Os subconjuntos obtidos apresentam uma relação de ordenação entre si, de tal forma que existe um subconjunto nãodominado (de nível 1) que domina todos os outros, um segundo (de nível 2) que domina os restantes com exceção do primeiro, até um subconjunto (de nível n) que não domina ninguém e é dominado por todos os anteriores.

O NSGA-II explora esse fato para atribuir valores de fitness aos indivíduos da população. Para isso, o algoritmo identifica os níveis de não-dominância existentes na população atual e as soluções que participam de cada nível. A partir daí, todas as soluções de cada nível "i" recebem o valor "i" como fitness. O algoritmo funciona sempre na direção de minimização, ou seja, soluções de níveis "mais baixos" têm mais chances de sobreviver. 
A Figura 23 mostra um exemplo da separação de um conjunto de soluções em níveis de não-dominância.

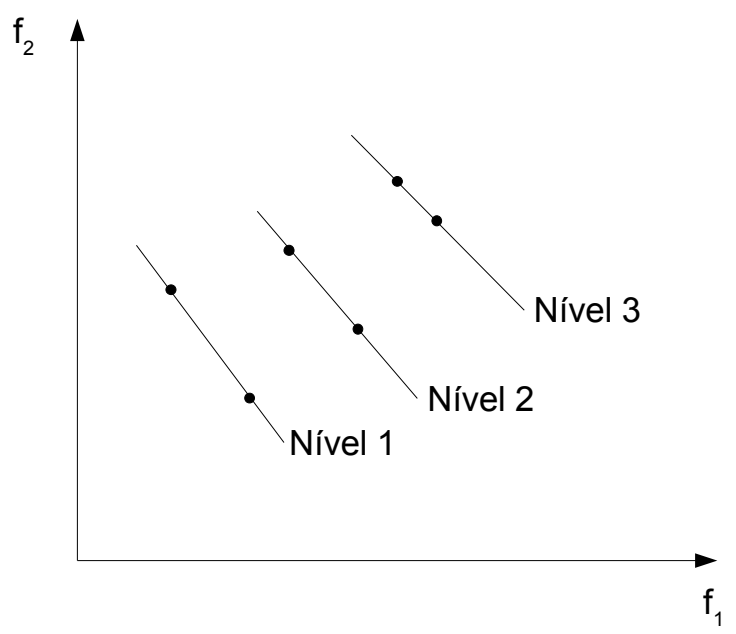

Figura 23. Níveis de não-dominância. Tanto $f_{1}$ quanto $f_{2}$ devem ser minimizadas

\subsubsection{Distância de crowding}

Segundo Deb (2001), os algoritmos evolucionários, quando aplicados a problemas multiobjetivos, têm que cumprir dois requisitos:

i. Convergir para a fronteira de Pareto;

ii. Encontrar um conjunto de soluções uniformemente distribuídas sobre a fronteira de Pareto.

O primeiro requisito é atendido pelo mecanismo de seleção e operadores genéticos já descritos. Para assegurar a diversidade das soluções sobre a fronteira de Pareto, é preciso utilizar um mecanismo que evite a concentração de indivíduos, formando regiões de alta densidade de soluções.

O NSGA-II utiliza a medida de distância de crowding para manter a 
diversidade da população atual. A principal vantagem dessa medida é que ela não necessita da especificação de nenhum parâmetro, ao contrário de outros mecanismos, como o compartilhamento de fitness (fitness sharing) e o Pareto niching, que demandam a determinação de um "raio de vizinhança" entre os indivíduos (HALLAM; BLANCHFIELD; KENDALL , 2005).

Para se calcular a medida de distância de crowding de um indivíduo, deve-se primeiro identificar seus vizinhos adjacentes em cada uma das dimensões (n funções-objetivo representam $\mathrm{n}$ dimensões). Em seguida, calcula-se a diferença dos valores objetivos dos indivíduos adjacentes em cada dimensão. O valor da distância de crowding é então a soma dessas diferenças. A Figura 24 exibe uma representação geométrica da distância de crowding, dada pelo perímetro do retângulo que envolve a solução.

Como a distância de crowding é uma medida do "vazio" em torno de uma solução, em regiões de maior densidade de soluções, a distância de crowding dos indivíduos é menor. Portanto, para preservar a diversidade, soluções de maior distância de crowding devem ser priorizadas.

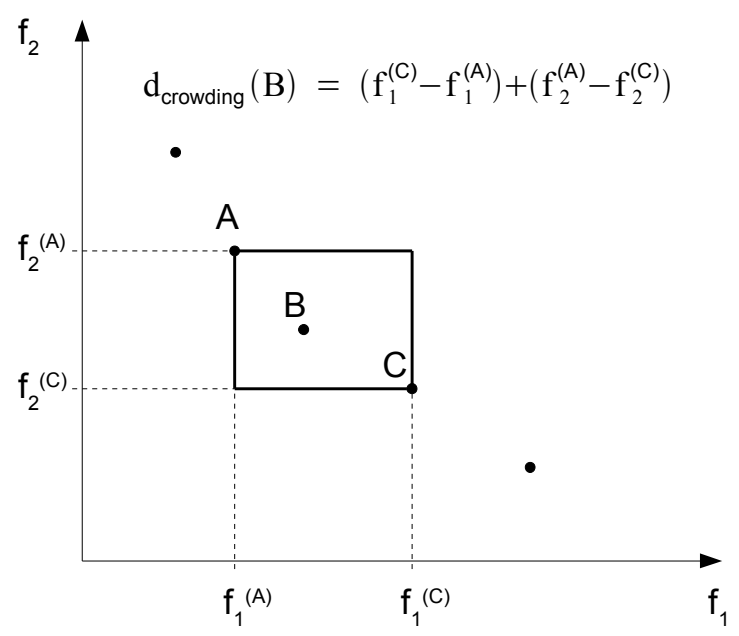

Figura 24. Interpretação geométrica da distância de crowding no espaço objetivo 
Em geral, o valor da distância de crowding é normalizado, visto que as soluções extremas possuem vizinhos apenas de um dos lados, e atribui-se teoricamente o valor infinito para sua distância de crowding.

\subsubsection{Torneio crowding}

O operador de torneio crowding é um operador de seleção que emprega a distância de crowding para comparar duas soluções. Basicamente, o operador compara as duas soluções quanto à dominância. Se uma dominar a outra, essa é a vencedora do torneio. Se ambas forem não-dominadas, a vencedora do torneio é aquela que possuir a maior distância de crowding.

\subsection{Considerações finais}

Neste capítulo apresentou-se a técnica de otimização multiobjetivo. Essa técnica tem papel preponderante na solução de problemas reais complexos, visto que a maioria desses problemas envolve essencialmente múltiplos objetivos conflitantes. Como o problema de formação de células de manufatura tem muitos aspectos a serem otimizados, adotar uma abordagem multiobjetivo é algo natural.

Existem muitas técnicas clássicas aplicadas à otimização multiobjetivo. No entanto, apresentam desvantagens que têm sido superadas pela aplicação de algoritmos evolucionários. Em destaque encontram-se a capacidade desses algoritmos de executar explorações paralelas no espaço de busca, gerando em apenas uma rodada um conjunto de soluções não-dominadas que se aproxima do conjunto ótimo de Pareto. 
110

No próximo capítulo serão apresentadas a simulação de eventos discretos e a otimização de modelos de simulação. Essa técnica será usada juntamente com os algoritmos genéticos para a formação de células de manufatura levando-se em consideração múltiplos objetivos. 


\section{OTIMIZAÇÃO BASEADA EM SIMULAÇÃO}

\subsection{Dinâmica de um sistema de manufatura como um processo estocástico}

Um sistema de manufatura pode ser representado matematicamente por um processo estocástico de nascimento e morte. Um processo estocástico é caracterizado por um conjunto de variáveis aleatórias $\mathbf{X}$ indexado no tempo, ou seja, para cada instante de tempo $t>0$, define-se uma variável aleatória $X_{t}$ (PAPOULIS; PILLAI, 2001).

No caso de um sistema de manufatura, pode-se considerar como variável aleatória $X_{t}$ o nível de inventário em processo - WIP - no instante t. As variáveis $X_{t}$ não são independentes, visto que dado uma realização $X_{t}=k$, a variável $X_{t+1}$ pode assumir apenas os valores $\mathrm{k}, \mathrm{k}-1$ ou $\mathrm{k}+1$.

Quando um sistema exibe esse tipo de comportamento probabilístico ao longo do tempo, fala-se que o sistema segue um processo estocástico de nascimento e morte (BUZACOTT; SHANTHIKUMAR, 1993). O Gráfico 2 exibe um exemplo desse tipo de processo.

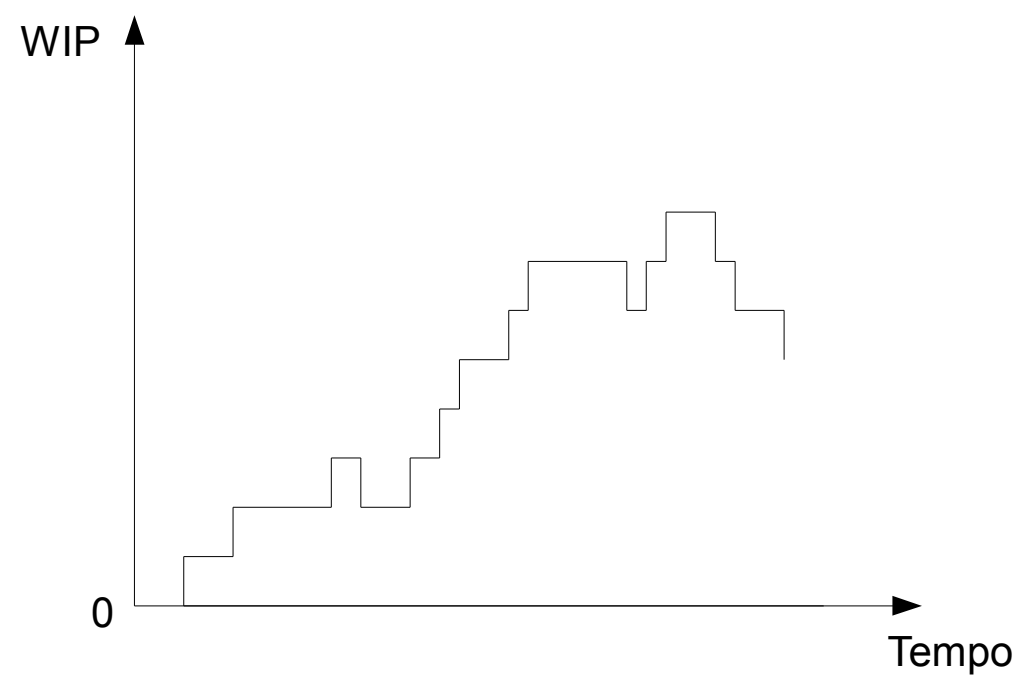

Gráfico 2. Evolução temporal do WIP representado como um processo estocástico de nascimento e morte 
Um sistema de manufatura apresenta dois estágios bem definidos durante sua operação: transiente e estacionário. Quando o estado estacionário é atingido, o valor médio do WIP ( e de outras variáveis de estado) se mantém constante ao longo do tempo (Gráfico 3).

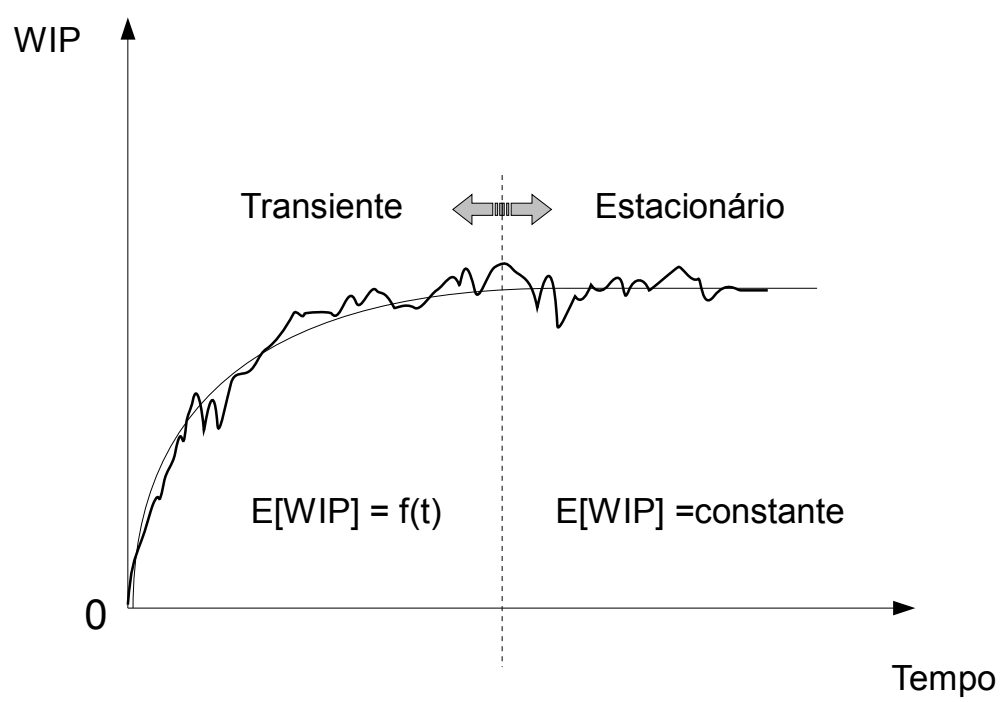

Gráfico 3. Estados transiente e estacionário em um sistema de manufatura

Por meio de simulação de eventos discretos é possível simular esse processo. Normalmente busca-se estimar o valor médio das variáveis de estado durante o regime estacionário, ou seja, quando o valor médio não varia com o tempo. Para isso, descarta-se das estimativas o período da simulação chamado de "tempo de aquecimento" (warm-up time), o qual equivale ao período transiente. 


\subsection{Simulação de eventos discretos}

A simulação trata da modelagem de um sistema real e da reprodução numérica de seu comportamento por meio de um programa de computador, com o objetivo de observar e estimar suas características (LAW; KELTON, 2000). Particularmente, a simulação de eventos discretos considera que as variáveis de estado de um sistema mudam de valor instantaneamente em pontos descontínuos do tempo. É uma ferramenta largamente utilizada para a análise e o projeto de sistemas de manufatura, graças à sua flexibilidade e capacidade de captar a variabilidade em sistemas complexos, principalmente sistemas com filas.

\subsubsection{Verificação e validação de modelos de simulação}

Após a construção de um modelo de simulação, são necessárias sua verificação e validação. Verificar um modelo de simulação refere-se a garantir que sua implementação computacional encontra-se livre de erros, enquanto validar refere-se a assegurar que o modelo permite atingir os objetivos do estudo para o qual foi desenvolvido (SARGENT, 2005).

\subsubsection{Uso de orientação a objetos em simulação de eventos discretos}

Inicialmente, a simulação de eventos discretos utilizava linguagens de programação estruturadas de uso genérico ou especificamente desenvolvidas para simulação. No entanto, com a ascensão do paradigma da programação orientada a objetos, usuários e pesquisadores começaram a se interessar pelo poder dessa 
técnica quando aplicada à simulação.

A orientação a objetos é um paradigma de programação sob o qual as funções e os dados manipulados por estas são agrupados em uma mesma unidade de código autocontida e independente chamada "objeto". Joines e Roberts (1999, p.140) afirmam que:

Modeling and simulation in an $\mathrm{O}-\mathrm{O}$ [Object-oriented] language possesses many advantages. [...] internal functionality of a language now becomes available to a user (at the discretion of the class designer). Such access means that existing behavior can be altered and new objects with new behavior introduced. The O-O approach provides a consistent means of handling these problems. ${ }^{9}$

De fato, a orientação a objetos surgiu da linguagem Simula, criada para a construção e execução de modelos de simulação. No entanto, apenas a partir de meados dos anos 90 surgiu o interesse em aplicar a orientação a objetos de forma mais efetiva na simulação.

Existem algumas linguagens e softwares que utilizam a orientação a objetos. Entre eles se destacam o módulo SimPy, para linguagem Python, a biblioteca $\mathrm{C}++\mathrm{Sim}$, para linguagem $\mathrm{C}++$, e o software $\mathrm{EM}$ - Plant (renomeado para Plant Simulation), da Tecnomatix, subsidiária da empresa UGS.

\subsection{Otimização baseada em de simulação de eventos discretos}

Dá-se o nome de "otimização da simulação", ou "otimização baseada em simulação" (utilizam-se ambos os termos intercambiavelmente neste texto) a técnicas de otimização estocástica que tentam estimar o valor da função-objetivo em um determinado vetor de decisão por meio da simulação (FU, 2002). Tais técnicas

9 A modelagem e simulação em uma linguagem orientada a objetos possuem muitas vantagens. [...] A funcionalidade interna de uma linguagem agora se torna acessível ao usuário (sob a discrição do projetista de classes). Tal acesso significa que comportamento existente pode agora ser modificado e novos objetos com novas funcionalidades podem ser introduzidos. A abordagem da orientação a objetos oferece um meio consistente para tratar tais problemas (Tradução própria). 
representam uma alternativa à otimização de modelos estocásticos de manufatura, visto que existem poucos modelos capazes de captar todas as nuances existentes em um sistema real, e os mesmos baseiam-se fortemente em hipóteses simplificadoras e restritivas (BUZZACOTT; SHANTHIKUMAR, 1993).

Fu, Glover e April (2005, p.88) ressaltam as vantagens da aplicação da otimização baseada em simulação:

\begin{abstract}
What is the most effective factory layout? What is the safest equipment replacement policy? What is the most cost effective inventory policy? What is the best workforce allocation? What is the most productive operating schedule? What is the best investment portfolio? [...] The answers to such questions require a painstaking examination of multiple scenarios, where each scenario in turn requires the implementation of an appropriate simulation or evaluation model to determine the consequences for costs, profits and risks. The critical "missing component" is to disclose which decision scenarios are the ones that should be investigated - and still more completely, to identify good scenarios automatically by a search process designed to find the best set of decisions. This is the core problem for simulation optimization in a practical setting. ${ }^{10}$
\end{abstract}

Um modelo de simulação pode ser usado para avaliar as funções-objetivo de um problema de otimização. Essa alternativa pode ser empregada quando a representação em uma fórmula matemática de medidas de desempenho de um sistema é difícil de ser obtida. Esse fato é recorrente em otimização de sistemas discretos com alta variabilidade, classe em que se inserem os sistemas de manufatura. Logo, o uso de um modelo de simulação de eventos discretos tem sido uma técnica utilizada para otimizar tais tipos de sistemas.

Encontram-se na literatura exemplos do uso da otimização da simulação em sistemas de manufatura, as quais se tornaram possíveis com o aumento

10 Qual é o arranjo físico mais eficiente? Qual a política de substituição de equipamentos mais segura? Qual é a melhor alocação de mão-de-obra? Qual a programação de operações mais produtiva? Qual o melhor portfolio de investimentos? [...] As respostas para tais questões requerem o exame exaustivo de múltiplos cenários, em que cada cenário por sua vez requer a implementação de um modelo adequado de simulação para determinar os impactos nos custos, lucros e risco. O ponto fulcral é descobrir quais cenários de decisão são aqueles que devem ser investigados - e mais ainda, identificar cenários promissores de forma automática por meio de um processo de busca desenvolvido para encontrar o melhor conjunto de decisões. Este é o problema central que a otimização da simulação tenta resolver em um situação prática. (Tradução própria) 
progressivo da capacidade computacional a partir do início dos anos 90. Azadivar e Tompkins (1999) utilizam um algoritmo genético e o paradigma da orientação a objetos para a otimização de um modelo de simulação de um sistema de manufatura considerando aspectos qualitativos. Pierreval e Paris (2003) tratam da otimização da própria configuração do modelo, e Azadivar e Wang (2000) apresentam uma aplicação no projeto de arranjos físicos funcionais. Pitombeira Neto e Gonçalves Filho (2007) utilizaram um algoritmo genético e um modelo de simulação de um arranjo físico distribuído com o objetivo de gerar arranjos físicos com baixo inventário médio em processo.

A Figura 25 exibe o esquema geral do procedimento de otimização da simulação.

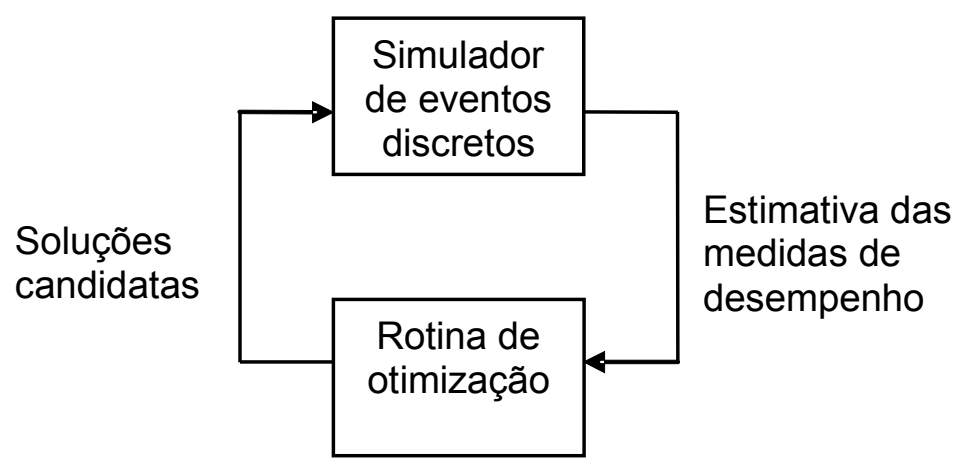

Figura 25. Procedimento geral de otimização da simulação (FU, 2002)

\subsection{Considerações finais}

Neste capítulo, fez-se uma breve explanação da otimização baseada em modelos de simulação de eventos discretos. Um modelo de simulação substitui a 
especificação analítica de funções-objetivo, possibilitando a inclusão no modelo de muitos fatores de difícil representação matemática. Essa característica é interessante para a abordagem de problemas multiobjetivos.

No próximo capítulo propõe-se o procedimento híbrido multiobjetivo para formação de células de manufatura, o qual integra as técnicas de simulação e otimização apresentadas nos capítulos anteriores: otimização multiobjetivo, algoritmos genéticos e simulação de eventos discretos. 



\section{PROCEDIMENTO HÍBRIDO PROPOSTO PARA FORMAÇÃO DE CÉLULAS DE MANUFATURA}

O problema considerado neste trabalho é o de formação de células de produção com réplicas de máquinas. Dadas as informações quanto aos produtos a serem fabricados, calcula-se a capacidade necessária de cada tipo de máquina, o que pode resultar em múltiplas máquinas (réplicas) de um mesmo tipo. Pretende-se então formar células de produção em que as réplicas de um tipo de máquina sejam distribuídas entre as células, e não todas alocadas a uma mesma célula.

\subsection{Esquema geral}

\subsubsection{Descrição}

O procedimento híbrido proposto utiliza um modelo de otimização multiobjetivo e um modelo de simulação de eventos discretos para representar o sistema de manufatura celular, o qual possui como parâmetros (considerados variáveis de decisão no modelo de otimização) os tipos e quantidades de máquinas existentes em cada célula. Informações específicas do problema, como tempos de processamento e seqüência de fabricação, devem ser fornecidas ao modelo de simulação. As medidas de desempenho resultantes da simulação são utilizadas como valores das funções-objetivo do modelo de otimização.

Dispondo-se então do modelo de simulação e dos dados específicos de uma instância do problema, um algoritmo genético realiza a otimização por meio de uma busca no espaço de configurações possíveis para o sistema de células de 
manufatura, avançando na direção de soluções Pareto-ótimas.

Para avaliar cada solução na população atual, o algoritmo requisita uma execução do modelo de simulação fornecendo ao mesmo os valores das variáveis de decisão (número de máquinas de cada tipo em cada célula). Os valores das funções-objetivo 1 e 2 - inventário médio em processo e movimentação de materiais entre células, respectivamente - são então obtidos a partir dos resultados da simulação, e o valor da função-objetivo 3 - investimento total em máquinas - é obtido por meio de cálculo matemático simples.

A Figura 26 exibe uma representação esquemática do procedimento proposto, enquanto o Quadro 7 contém o pseudo-código.

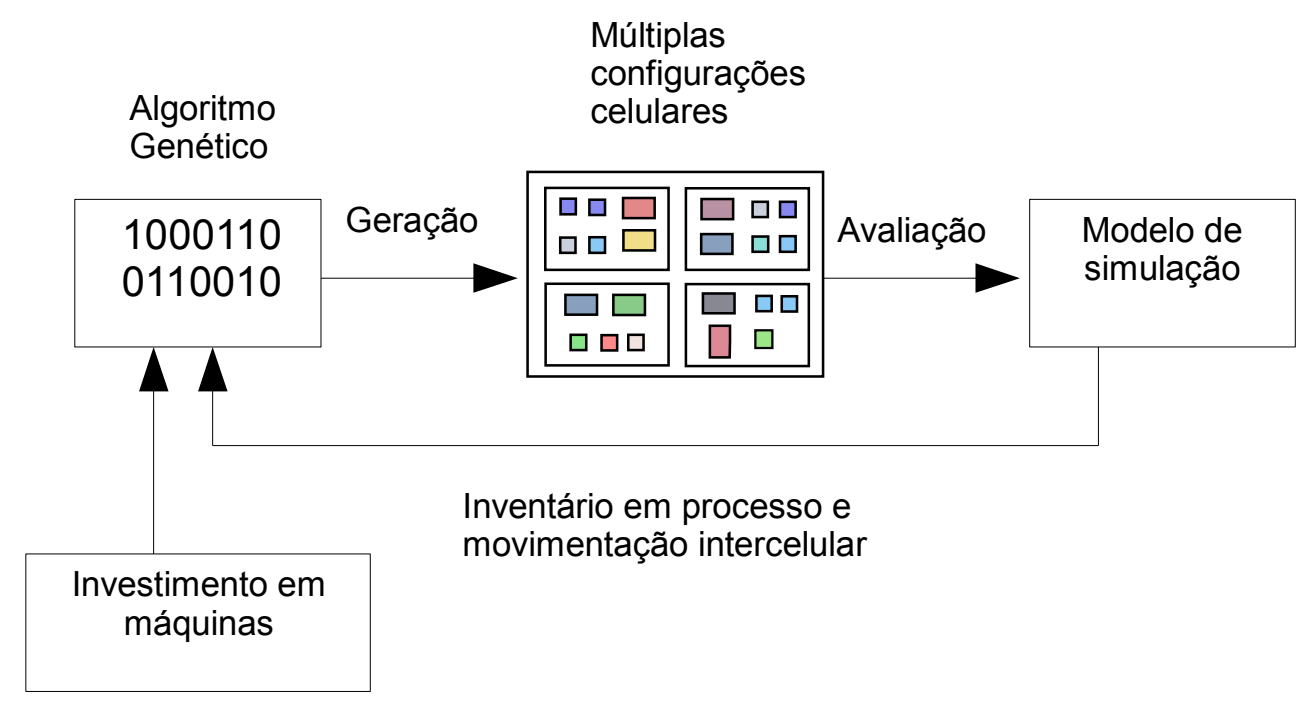

Figura 26. Representação esquemática do procedimento híbrido de otimização multiobjetivo proposto 


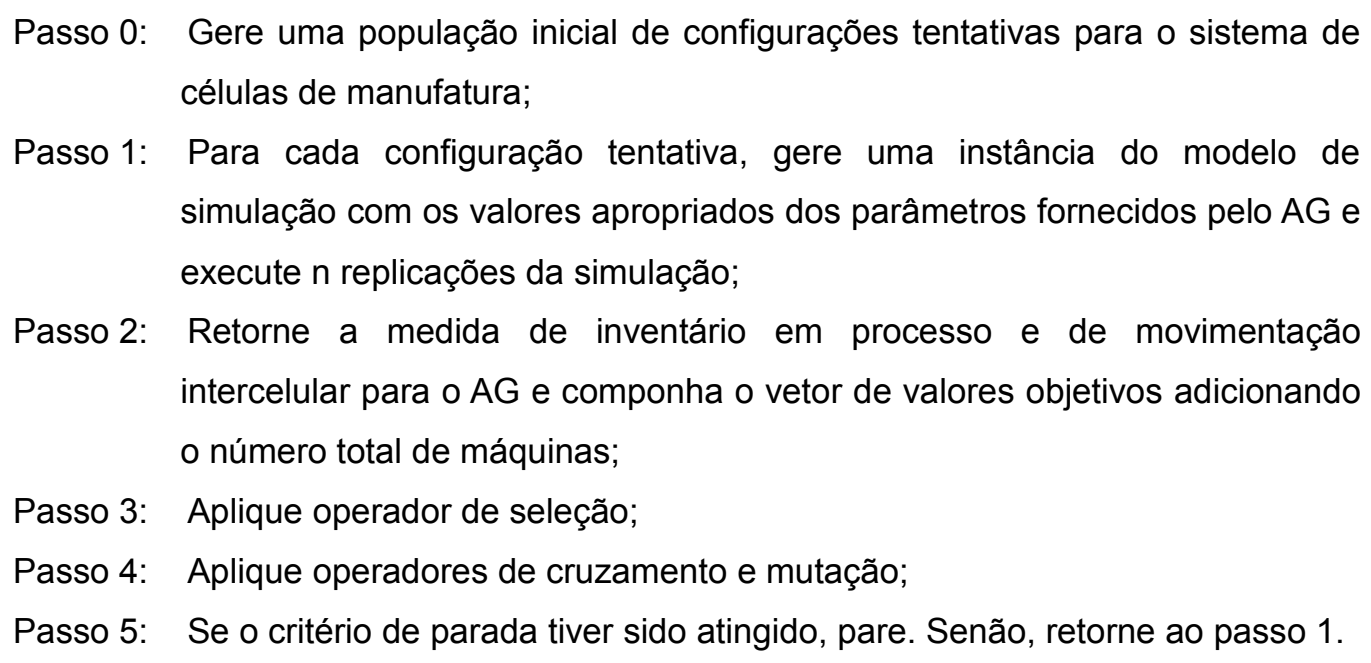

Quadro 7. Pseudo-código do procedimento híbrido de otimização multiobjetivo proposto

6.1.2 Características de um sistema de manufatura celular representadas no modelo de simulação

O modelo de simulação desenvolvido representa as seguintes características de um sistema de manufatura celular:

- Múltiplas réplicas de um tipo de máquina;

- Rotas alternativas de para a fabricação de peças;

- Formação de filas devido à variabilidade na chegada e no processamento;

- Movimentação intercelular de lotes;

- Variação na capacidade do sistema devido à mudança no número de máquinas;

- Capacidade protetiva;

- Presença e impacto de gargalos de produção; 
necessário):

- Fracionamento de lotes (lot-splitting);

- Modelagem explícita do sistema de movimentação de materiais;

- Operadores de máquinas;

- Tempos de setup.

\subsubsection{Informações do problema}

O procedimento proposto requer as seguintes informações quanto ao sistema de manufatura celular a ser formado, as quais são fornecidas ao modelo de simulação:

- Demanda estimada de longo prazo dos produtos a serem fabricados;

- Seqüência de fabricação dos produtos;

- Tempos de processamento dos produtos em cada máquina;

- Tipos de máquinas necessárias ao processamento dos produtos;

- Valor de investimento das máquinas (opcional);

- Tempo disponível na máquina para processamento (descontando-se tempos estimados de manutenção);

Além disso, o modelo possui alguns parâmetros constantes (não considerados como variáveis de decisão no modelo de otimização) a serem escolhidos pelo analista: 
- Número de células a serem formadas;

- Tamanho máximo da célula em número de máquinas;

- Número máximo de máquinas de mesmo tipo por célula.

A seguir, discutem-se algumas diretrizes sobre como escolher os valores dos parâmetros constantes.

Tamanho máximo da célula em número de máquinas

O tamanho máximo da célula depende de muitos fatores, entre eles: a área ocupada pelas máquinas, segurança do operador, sistema de movimentação, e efeitos ambientais. Por sua vez, esses fatores variam consideravelmente de acordo com o tipos de processos de fabricação empregados pela empresa. Como tais características não foram levadas em consideração neste trabalho, o tamanho máximo admissível da célula é uma restrição imposta pelo projetista do sistema de manufatura celular de acordo com as particularidades do processo de fabricação, não sendo considerada uma variável de decisão no procedimento de otimização.

Número de células a serem formadas

O número de células também depende de muitos fatores particulares, entre eles o tipo de produto a ser fabricado, os tipos de máquina, a demanda prevista, e o porte da fábrica. Wemmerlöv e Johnson (1997), em um levantamento de 46 empresas nos Estados Unidos, relatam o número médio de células igual a 8,4 por planta. Neste trabalho, mais uma vez, o número de células é um parâmetro de 
entrada, o qual não compõe o conjunto de variáveis de decisão.

Número máximo de máquinas de mesmo tipo por célula

Esse número é determinante para a qualidade das soluções obtidas, visto que ele impacta diretamente no tamanho do espaço de busca. Quanto maior o espaço de busca, maior o esforço computacional para a aproximação de soluções ótimas.

Para ilustrar a questão, tome-se N como o número de células desejadas e M o número de tipos de máquinas. Uma solução para o problema é uma matriz NxM na qual um elemento $a_{i j}$ é um número inteiro que varia de 0 a $S_{i j}$, o número máximo de máquinas do tipo j na célula i. Caso escolha-se todos os $S_{i j}$ idênticos, ou seja, $S_{i j}$ = S para todo i e j, tem-se que o número de soluções possíveis é de $\mathrm{S}^{\mathrm{NM}}$.

A escolha de valores grandes de $S_{i j}$ permite maior exploração das soluções do problema, mas incorre em maior esforço computacional. Ao contrário, valores pequenos permitem um tempo menor de convergência, mas carregam consigo o risco de algumas soluções ótimas não serem alcançáveis (ou até mesmo todas as soluções ótimas, em um caso extremo).

Portanto, caso o analista ou projetista possuam conhecimento sobre valores mais prováveis para o número máximo de máquinas nas células, essa informação pode melhorar o processo de obtenção de soluções ótimas como um todo.

Uma maneira possível de estimar os valores de $S_{i j}$ é dividir o número mínimo de máquinas do tipo j, obtido segundo a equação (1), pelo número de células e adicionar uma constante inteira $\mathrm{k}$ e $\mathbb{Z}^{+}$(equação (27)). Dessa forma, 
utiliza-se algum conhecimento sobre o problema para gerar um espaço de busca menor e possivelmente diminuindo o risco de que algumas soluções ótimas tornemse inatingíveis.

$$
S_{i j}=\left\lceil\frac{R_{j}}{N}\right\rceil+k \quad i=1,2, \ldots, N ; \quad j=1,2, \ldots, M
$$

\subsubsection{Funções-objetivo}

O modelo de otimização para formação de células de manufatura inclui as seguintes funções-objetivo:

- Movimentação de materiais entre células (Mov): Essa é a medida mais usada para o projeto de sistemas celulares. Idealmente, um sistema celular deveria ser composto de células independentes;

- Inventário em processo (WIP): Em modelos da literatura, costuma-se utilizar o balanceamento de carga dentro da célula como forma de diminuir o inventário em processo (Work-in-process, WIP). No entanto, uma estimativa mais precisa do WIP pode ser obtida utilizando-se equações da Teoria das Filas, ou modelos de Simulação. Ao reduzir WIP também se reduz automaticamente o tempo de atravessamento (Lead Time) dos produtos;

- Investimento total em máquinas (Inv): Ao se replicar máquinas, obtém-se maior capacidade, o que contribui para a diminuição de WIP. Adicionalmente, um número maior de réplicas de máquinas possibilita 
maior distribuição dessas entre as células, contribuindo para a diminuição da movimentação intercelular.

\subsubsection{Formulação matemática do modelo de otimização}

As equações (28) a (33) descrevem matematicamente a abordagem do problema de otimização da simulação de células de manufatura com múltiplas réplicas.

$$
\begin{array}{cc}
\min \quad \mathrm{f}_{1}(\mathbf{X}, \Phi)=\mathrm{E}[\mathrm{WIP}(\mathbf{X}, \Phi)] \\
\min \quad \mathrm{f}_{2}(\mathbf{X}, \Phi)=\mathrm{E}[\operatorname{Mov}(\mathbf{X}, \Phi)] \\
\min \quad \mathrm{f}_{3}(\mathbf{X}, \mathbf{w})=\operatorname{Inv}(\mathbf{X}, \mathbf{w})=\sum_{\mathrm{i}=1}^{\mathrm{N}} \sum_{\mathrm{j}=1}^{\mathrm{M}} \mathrm{w}_{\mathrm{j}} \mathrm{x}_{\mathrm{ij}}
\end{array}
$$

sujeito a

$$
\begin{gathered}
\sum_{\mathrm{i}=1}^{\mathrm{N}} \mathrm{x}_{\mathrm{ij}} \geq \mathrm{m}_{\mathrm{j}} \quad \forall \mathrm{j}, \mathrm{j}=1,2, \ldots, \mathrm{M} \\
\sum_{\mathrm{j}=1}^{\mathrm{M}} \mathrm{x}_{\mathrm{ij}} \leq \mathrm{C} \quad \forall \mathrm{i}, \mathrm{i}=1,2, \ldots, \mathrm{N} \\
\mathrm{x}_{\mathrm{ij}} \in\left\{0,1,2 \ldots \mathrm{S}_{\mathrm{ij}}\right\} \quad \forall \mathrm{i}, \mathrm{j}
\end{gathered}
$$

em que:

$\mathrm{f}_{1}$ - Inventário em processo, em unidades de peças ou produtos. Valor médio é estimado pela simulação;

$f_{2}$ - Movimentação intercelular, em número de transferências entre células. Valor médio é estimado pela simulação; 
$\mathrm{f}_{3}$ - Investimento em máquinas, em valor monetário total ou número total de unidades de máquinas. Valor determinístico;

$\Phi$ - Modelo de simulação;

N - Número de células de produção;

M - Número de tipos de máquinas;

$\mathrm{m}_{\mathrm{j}}$ - Número mínimo de réplicas de máquina do tipo j dado pelo cálculo de capacidade;

C - Número máximo de máquinas admissível por célula;

$\mathrm{w}_{\mathrm{j}}$ - Custo de uma réplica de máquina do tipo j;

$\mathrm{S}_{\mathrm{ij}}$ - Número máximo admissível de máquinas do tipo j na célula i;

$\mathrm{X}_{\mathrm{ij}}$ - Número de máquinas do tipo j na célula i (componente da matriz $\mathbf{X}$ );

w - Vetor de custos de uma unidade de cada tipo de máquina

X - Matriz de variáveis de decisão;

As expressões (28), (29) e (30) são as funções-objetivo (ou medidas de desempenho). A expressão (28) representa o valor esperado do inventário em processo (WIP) e a expressão (29) representa o valor esperado da movimentação intercelular (Mov). Ambas são variáveis aleatórias, e apenas suas estimativas são obtidas pelo modelo de simulação. Já a expressão (30) representa o investimento total em máquinas, uma função determinística do número de réplicas de cada tipo de máquina e do seus custos.

A equação (31) representa a restrição do número mínimo de máquinas de cada tipo, resultante do cálculo de capacidade; a equação (32) representa a restrição do número máximo de máquinas em uma célula; e a equação (33) define o domínio das variáveis de decisão. 
Dado que o problema deve formar $\mathrm{N}$ células e possui $\mathrm{M}$ tipos de máquinas, existem $\mathrm{MN}$ variáveis de decisão (tamanho da matriz $\mathbf{X}$ ), $\mathrm{N}$ restrições quanto ao número máximo de máquinas por célula (equação (32)), M restrições quanto ao número mínimo de réplicas por tipo de máquina (equação (31)) e MN restrições quanto ao máximo de réplicas por tipo por célula (equação (33)).

\subsection{Modelo de simulação de eventos discretos}

\subsubsection{Descrição}

O sistema de manufatura celular é representado por um modelo computacional baseado em simulação de eventos discretos orientada a objetos, em vez de um conjunto de equações matemáticas que estabelecem relações entre variáveis-chave do sistema.

O modelo é composto por um conjunto de classes de objetos, as quais representam os elementos que compõem o sistema de manufatura celular.

São usadas as seguintes classes:

- Célula: Composta por um conjunto de máquinas;

- Máquina: Recurso utilizado pelos produtos a serem processados;

- Ordem de produção: Possui as especificações do tipo de produto, a seqüência de fabricação, os tempos de processamento e o tamanho do lote;

- Demanda: Gera as ordens de produção de acordo com uma distribuição de probabilidades definida; 
Em células com mais de uma réplica de um tipo de máquina, as réplicas participam do processo de produção como se compusessem um pequeno departamento funcional, em que os lotes a serem processados esperam em uma fila única. A Figura 27 ilustra esse caso.

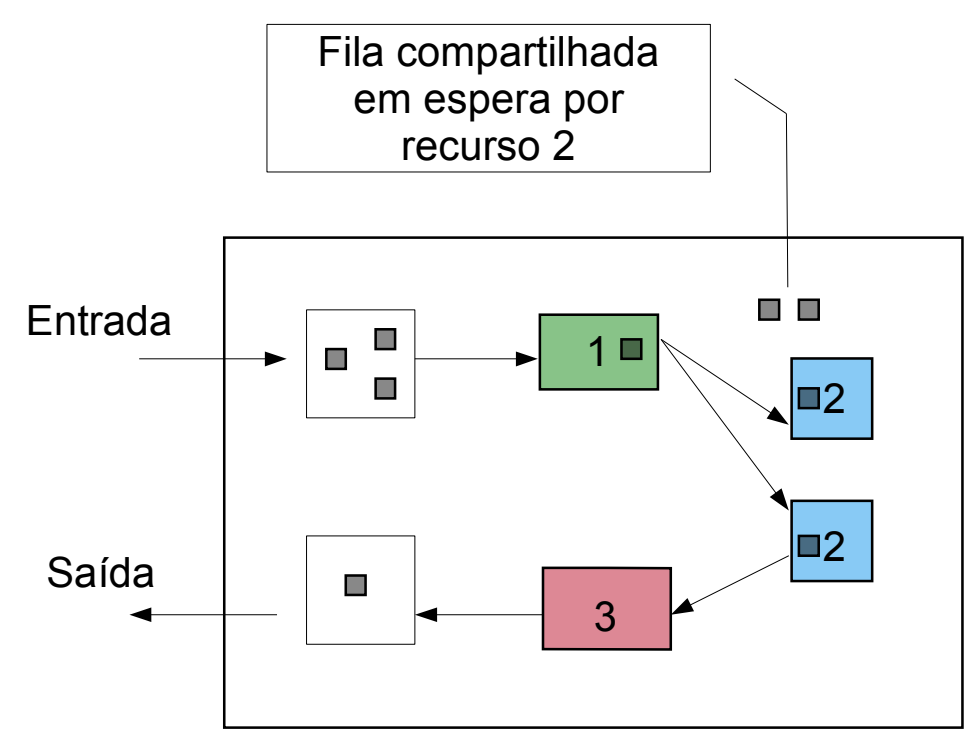

Figura 27. Célula de manufatura com duas réplicas da máquina tipo 2. Os lotes esperam em uma mesma fila pela liberação de umadas duas réplicas

Com a presença de réplicas de um mesmo tipo de máquina, surge um problema de roteamento: por quais réplicas e em quais células um lote deve ser roteado? Deve-se então adotar uma política de roteamento para os lotes de produção. A Figura 28 mostra rotas alternativas entre células para um mesmo lote de produção. A rota 1 envolve 2 células de manufatura, enquanto a rota 2 apenas 1 célula. A rota 1 pode ser escolhida na prática se a célula 2 estiver sobrecarregada. 


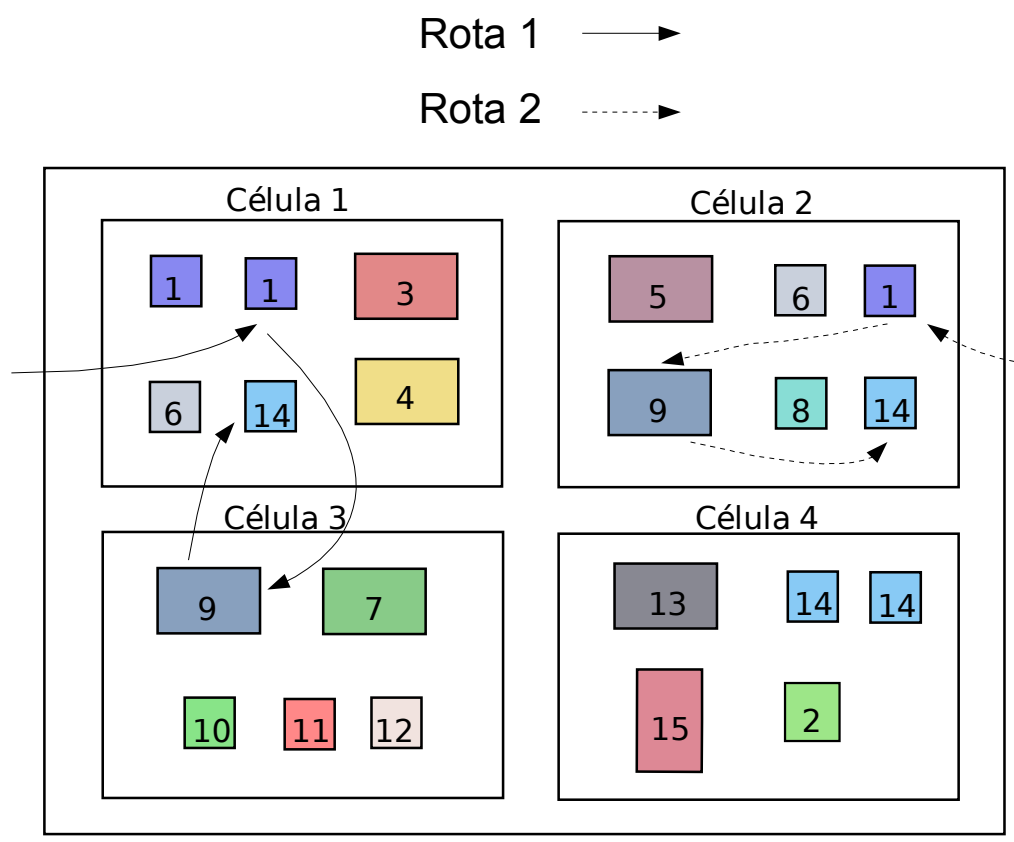

Seqüência: 1 - 9 - 14

Figura 28. Rotas alternativas para um produto. Na rota 1 o produto é processado em 2 células, realizando 2 movimentos intercelulares, enquanto na rota 2 ele é completamente processado em apenas uma célula

A política adotada nesse modelo é baseada no princípio de equilibração de cargas nas células. Ou seja, tenta-se rotear os lotes para células com menores filas de espera se a célula em que o produto se encontra atualmente não contiver o tipo de máquina requerido. O Quadro 8 exibe o pseudo-código da política utilizada para o roteamento.

Passo 0: Verifique qual célula dispõe do tipo de máquina para iniciar o processamento e roteie para esta célula. Se múltiplas células dispuserem do tipo de máquina, escolha aquela com menor inventário em espera;

Passo 1: Repita até o fim do processamento do lote:

Se a célula atual possuir o tipo de máquina necessário ao próximo processamento, permaneça na célula. Senão, identifique as células que dispõem do tipo de máquina e escolha aquela com menor inventário em espera.

Quadro 8. Pseudo-código da política de roteamento de lotes adotada 
No Apêndice A encontra-se o código-fonte do modelo de simulação escrito em linguagem Python.

\subsubsection{Verificação e validação do modelo de simulação desenvolvido}

Neste trabalho não serão detalhados os procedimentos usados para verificar o modelo de simulação, visto que são comuns aos procedimentos utilizados para qualquer programa de computador.

Para a validação do modelo, foi usado o conjunto de dados de Wu (1998). O modelo de simulação foi rodado e seus resultados foram comparados com estimativas teóricas. A configuração do sistema celular utilizada foi uma modificação da solução proposta por $\mathrm{Wu}$, visto que sua solução é inviável em termos operacionais (como será mostrado na seção 7.1). A distribuição de máquinas nas células foi mantida, mas o número de unidades de cada tipo de máquina em cada célula foi incrementado em 1 unidade. A Tabela 5 exibe a configuração usada.

Tabela 5 - Configuração do sistema de manufatura celular utilizada - Adaptado de Wu (1998)

\begin{tabular}{cccccccccccccc}
\hline \multirow{2}{*}{ Célula } & \multicolumn{11}{c}{ Tipo de máquina } \\
\cline { 2 - 14 } & 1 & 2 & 3 & 4 & 5 & 6 & 7 & 8 & 9 & 10 & 11 & 12 & 13 \\
\hline 1 & 2 & 2 & 0 & 0 & 0 & 2 & 3 & 0 & 0 & 0 & 0 & 0 & 0 \\
2 & 0 & 0 & 0 & 0 & 3 & 0 & 0 & 2 & 2 & 0 & 0 & 2 & 2 \\
3 & 2 & 0 & 2 & 2 & 2 & 0 & 0 & 2 & 0 & 2 & 2 & 0 & 0 \\
\hline
\end{tabular}

As Tabelas 6 e 7 contém os parâmetros da simulação, e a Tabela 8 contém os resultados obtidos. 
Tabela 6 - Parâmetros de simulação utilizados na validação do modelo de simulação

\begin{tabular}{cc}
\hline Parâmetro & Valor adotado \\
\hline Tempo simulado (minutos) & 9600 \\
Tempo de aquecimento (minutos) & 2400 \\
Número de replicações & 30 \\
\hline
\end{tabular}

Tabela 7 - Parâmetros do problema utilizados na validação do modelo de simulação

\begin{tabular}{lc}
\hline \multicolumn{1}{c}{ Parâmetro } & Valor adotado \\
\hline $\begin{array}{l}\text { Tempo disponível em uma } \\
\text { máquina (minutos por mês) }\end{array}$ & 9600 \\
$\begin{array}{l}\text { Tamanho de lote (unidade) } \\
\text { Distribuição de probabilidades } \\
\text { dos tempos entre chegadas }\end{array}$ & 1 \\
$\begin{array}{l}\text { Distribuição de probabilidades } \\
\text { dos tempos de processamento }\end{array}$ & Exponencial \\
\hline
\end{tabular}

Tabela 8 - Comparações entre resultados teóricos e simulados

\begin{tabular}{|c|c|c|c|c|}
\hline \multirow[b]{2}{*}{ Fator avaliado } & \multirow{2}{*}{$\begin{array}{l}\text { Teórico } \\
\text { (média) }\end{array}$} & \multicolumn{3}{|c|}{ Simulado } \\
\hline & & Média & $\begin{array}{l}\text { Desvio- } \\
\text { padrão }\end{array}$ & $\begin{array}{c}\text { Intervalo de } \\
\text { confiança }(95 \%)\end{array}$ \\
\hline $\begin{array}{c}\text { Demanda total } \\
\text { (lotes) }\end{array}$ & 5380 & 5394,00 & 71,99 & {$[5368,24 ; 5419,76]$} \\
\hline $\begin{array}{l}\text { Inventário total } \\
\text { médio em } \\
\text { processo (lotes) }\end{array}$ & $\begin{array}{l}\text { 17,482 (Lei } \\
\text { de Little) }\end{array}$ & 17,597 & 0,53962 & {$[17,404 ; 17,790]$} \\
\hline $\begin{array}{l}\text { Tempo de } \\
\text { atravessamento } \\
\text { (minutos) }\end{array}$ & $\begin{array}{l}22,71 \text { (cota } \\
\text { inferior) }\end{array}$ & 31,113 & 0,13176 & {$[31,066 ; 31,160]$} \\
\hline
\end{tabular}

$\mathrm{Na}$ Tabela 8, a demanda total e o inventário médio simulados são condizentes com previsões teóricas.

A "quantidade de trabalho" para um produto refere-se à soma de todos os tempos de processamento para completá-lo (HOPP; SPEARMAN, 2000). Ou seja, o tempo de atravessamento mínimo possível para um produto é o tempo total necessário para processá-lo. Qualquer tempo adicional diz respeito a perdas 
decorrentes de espera em filas, movimentação, entre outras perdas (LIKER, 2003). Em outras palavras, o tempo de atravessamento deve sempre ser maior que a quantidade de trabalho, o que é verdade para o modelo simulado.

A partir dos resultados coerentes exibidos na Tabela 8 e do rastreamento da execução do modelo (Apêndice B), pode-se concluir que há forte evidência de que o comportamento do modelo é muito próximo ao de um sistema de manufatura celular.

\subsection{Algoritmo genético desenvolvido}

O algoritmo genético proposto para solucionar o problema é baseado no NSGA-II, como descrito na seção 4.4.1.

\subsubsection{Representação genética utilizada}

Uma solução do problema é representada por uma matriz de inteiros $\mathbf{X}$, na qual a linha i corresponde à célula i, e a coluna j corresponde ao tipo de máquina j. Logo, um elemento $x_{i j}$ da matriz $\mathbf{X}$ representa o número de réplicas do tipo de máquina j presentes na célula i (Figura 29). 


$$
\mathbf{X}=\left[\begin{array}{cccccc}
\mathrm{x}_{11} & \mathrm{x}_{12} & \ldots & \mathrm{x}_{1 \mathrm{j}} & \ldots & \mathrm{x}_{1 \mathrm{M}} \\
\mathrm{x}_{21} & \mathrm{x}_{22} & \ldots & \mathrm{x}_{2 \mathrm{j}} & \ldots & \mathrm{x}_{2 \mathrm{M}} \\
\cdot & \cdot & . & \cdot & . & \cdot \\
\cdot & \cdot & \cdot & \cdot & . & \cdot \\
\mathrm{x}_{\mathrm{N} 1} & \mathrm{x}_{\mathrm{N} 2} & \ldots & \mathrm{x}_{\mathrm{Nj}} & \ldots & \mathrm{x}_{\mathrm{NM}}
\end{array}\right] \quad \mathbf{A}=\left[\begin{array}{ccccc}
0 & 1 & 2 & 0 & 2 \\
1 & 0 & 0 & 3 & 1 \\
2 & 1 & 1 & 0 & 1 \\
0 & 0 & 2 & 1 & 2
\end{array}\right] \text { Célula } 1
$$

Tipo de máquina: 3

Figura 29. Representação matricial de uma solução do problema

\subsubsection{Geração da população inicial}

Para gerar a população inicial, utilizou-se um procedimento híbrido, que utiliza informação do problema para gerar metade da população, e gera a outra metade de forma puramente aleatória. O Quadro 9 contém o pseudo-código do procedimento de inicialização. A razão para isso é que se conhece, por meio do cálculo de capacidade, as cotas inferiores para cada tipo de máquina. Logo, o procedimento de inicialização cria metade dos indivíduos aplicando uma perturbação aleatória à solução com número mínimo de máquinas, e o resto da população é gerada aleatoriamente, para que o algoritmo não inicie viciado em apenas uma região localizada do espaço de busca.

Passo 0: Faça $\mathrm{k}=0$;

Passo 1: Enquanto $k<N / 2$, gere $o$ indivíduo $n$ atribuindo a cada elemento $x_{i j}$ um valor gerado a partir de $U\left(R_{j}, S_{i j}\right)$ inclusive. Faça $k=k+1$;

Passo 2: Enquanto $k>N / 2$ e $k<N$, gere $o$ indivíduo $k$ atribuindo a cada elemento $x_{i j}$ um valor gerado a partir de $U\left(0, S_{i j}\right)$ inclusive. Faça $k=k+1$;

Quadro 9. Procedimento para geração da população inicial

No Quadro 9: 
k - Indivíduo atual;

$\mathrm{N}$ - Tamanho da população;

$U(a, b)$ - Distribuição de probabilidades uniforme discreta;

$R_{\mathrm{j}}$ - Número mínimo de unidades (réplicas) de máquina do tipo $\mathrm{j}$, obtido pela equação (1);

$S_{i j}$ - Número máximo admissível de unidades (réplicas) de máquina do tipo j na célula i.

\subsubsection{Procedimento de correção de não-factibilidade}

Para tratar as restrições, optou-se pelo uso de um procedimento para correção de não-factibilidade. Cada vez que um indivíduo na população é gerado ou modificado por meio de inicialização ou aplicação de operadores, aplica-se em seguida o operador de correção que verifica se o indivíduo viola alguma das restrições. Caso positivo, o procedimento torna o indivíduo factível.

Existem basicamente 2 tipos de restrições no problema que não são inerentemente respeitadas pela representação matricial adotada: número de máquinas de um tipo ao longo das células deve se manter maior que um valor mínimo dado pelo cálculo de capacidade, e número de máquinas (de todos os tipos) em uma mesma célula deve ser menor ou igual a um valor máximo estabelecido pelo projetista.

Para corrigir o número de máquinas em uma célula, quando este é maior que o máximo, identificam-se primeiro as máquinas naquela célula que têm número maior que o mínimo necessário. Em seguida, sorteiam-se máquinas para serem 
retiradas da célula entre aquelas com número maior que o mínimo até que a célula possua o número de máquinas igual ao máximo admissível por célula.

Quando a restrição do número mínimo de máquinas é violado, sorteia-se uma célula e adiciona-se uma máquina daquele tipo. Repete-se o procedimento até atingir o número mínimo de máquinas necessário.

\subsubsection{Operador de cruzamento}

O operador de cruzamento é um operador binário que atua sobre duas soluções "pais" e produz duas soluções "filhas" derivadas. Neste trabalho experimentaram-se dois operadores de cruzamento: uniforme e "par-ímpar". Não observou-se diferença de desempenho, de tal forma que optou-se pelo operador uniforme.

O operador uniforme atua da seguinte maneira: para cada posição $x_{i j} d a$ matriz de solução, sorteia-se o elemento da matriz-pai 1 ou matriz-pai 2, e o elemento sorteado fará parte da matriz-filho 1 . Procede-se até que a matriz-filho 1 esteja completamente composta. Os elementos remanescentes não sorteados compõem a matriz-filho 2. A Figura 30 ilustra o funcionamento do operador uniforme. 


$\begin{array}{llllllllllll} & 1 & \mathbf{1} & 1 & \mathbf{1} & 1 & & \mathbf{2} & 2 & \mathbf{2} & 2 & \mathbf{2} \\ \text { Pai } 1 & \mathbf{1} & \mathbf{1} & 1 & \mathbf{1} & 1 & \text { Pai } 2 & 2 & 2 & \mathbf{2} & 2 & \mathbf{2} \\ & 1 & 1 & 1 & \mathbf{1} & 1 & & \mathbf{2} & \mathbf{2} & \mathbf{2} & 2 & \mathbf{2} \\ & & & & & & & & & & & \\ & \mathbf{2} & \mathbf{1} & \mathbf{2} & \mathbf{1} & \mathbf{2} & & 1 & 2 & 1 & 2 & 1 \\ \text { Filho } 1 & \mathbf{1} & \mathbf{1} & \mathbf{2} & \mathbf{1} & \mathbf{2} & \text { Filho } 2 & 2 & 2 & 1 & 2 & 1 \\ & \mathbf{2} & \mathbf{2} & \mathbf{2} & \mathbf{1} & \mathbf{2} & & 1 & 1 & 1 & 2 & 1\end{array}$

Figura 30. Atuação do operador uniforme. Os elementos em negrito foram sorteados para compor o filho 1

\subsubsection{Operador de mutação}

A função da mutação é inserir novos elementos e manter a diversidade da população. No algoritmo genético implementado, o operador de mutação sorteia aleatoriamente uma célula e um tipo de máquina, e então sorteia um número entre zero e $\mathrm{S}_{\mathrm{i}}$, o número máximo admissível de máquinas do tipo j na célula i. A Figura 31 ilustra a aplicação do operador de mutação.

$\begin{array}{llllll}1 & 1 & 1 & 1 & 1 \\ \text { Indivíduo original } & 1 & 1 & 1 & 1 & 1 \\ 1 & 1 & 1 & 1 & 1\end{array} \longrightarrow$ Indivíduo mutado $\begin{array}{lllll}1 & 1 & 3 & 1 & 1 \\ 1 & 1 & 1 & 1 & 1 \\ 1 & 1 & 1 & 1 & 1\end{array}$

Figura 31. Exemplo da aplicação do operador de mutação 


\subsection{Procedimento de clusterização da população final}

O uso de algoritmos evolucionários para a aproximação da fronteira de Pareto exige o uso de populações grandes. De fato, quanto maior a população, melhor e mais rápida a convergência, embora exija o uso crescente de recursos computacionais. Após a execução do algoritmo, a população final representa uma aproximação do conjunto ótimo de Pareto. Como normalmente a população tem muitos indivíduos (neste trabalho trabalhou-se com tamanho 50), dispõe-se de um conjunto grande de soluções não-dominadas. Isso dificulta a análise das alternativas para a seleção da mais adequada. Deve-se então tentar reduzir esse conjunto para um tamanho tratável, mas mantendo ao máximo a diversidade e informação do conjunto não-dominado.

$\mathrm{Na}$ literatura são relatadas boas experiências com algoritmos de análise de agrupamentos (Cluster Analysis), especialmente algoritmos hierárquicos, como o SLC e o ALC, já apresentados em seções anteriores. Zitzler e Thiele (1999) têm reportado excelentes resultados com ALC em seu algoritmo evolucionário multiobjetivo SPEA, e por essa razão esse algoritmo foi utilizado neste trabalho para a redução da população final.

O procedimento de redução então aplica o ALC à população final, formando o dendograma de clusterização. A seguir, são identificados n clusters para uma redução da população final para um conjunto de n soluções não-dominadas. Por fim, em cada um dos $n$ clusters, identifica-se a solução mais próxima do centróide do cluster, a qual comporá o conjunto reduzido de soluções nãodominadas.

O Quadro 10 descreve o pseudo-código do procedimento. 
Passo 1: Aplique o ALC à população final de soluções;

Passo 2: Identifique $\mathrm{n}$ clusters no dendograma formado;

Passo 3: Forme o conjunto reduzido a partir da seleção em cada um dos $\mathrm{n}$ clusters da solução mais próxima de seu centróide.

Quadro 10. Procedimento para redução da população final

\subsection{Implementação computacional}

\subsubsection{Modelo de simulação}

Para realizar a simulação, foi utilizada a biblioteca SimPy 1.8 para linguagem Python. Essa biblioteca possui um conjunto de classes e funções para a realização de simulação de eventos discretos com base no paradigma da orientação a objetos (BAHOUTH et al., 2007). É livre e de código fonte aberto, sendo licenciada pela Lesser Gnu Public License - LGPL que permite o desenvolvimento de softwares acadêmicos e comerciais sem a necessidade de pagamento de royalties.

Python é uma linguagem interpretada de altíssimo nível. Ela suporta diversos paradigmas de programação, entre eles: orientação a objetos, programação funcional e programação genérica. Possui uma extensa biblioteca padrão e módulos desenvolvidos por terceiros, sendo largamente utilizada por empresas e órgãos públicos, tais como universidades, Google e NASA. Neste trabalho utilizou-se a versão Python 2.5 .

O Quadro 11 exibe um trecho de código do modelo de simulação em Python, descrevendo a classe "máquina". 


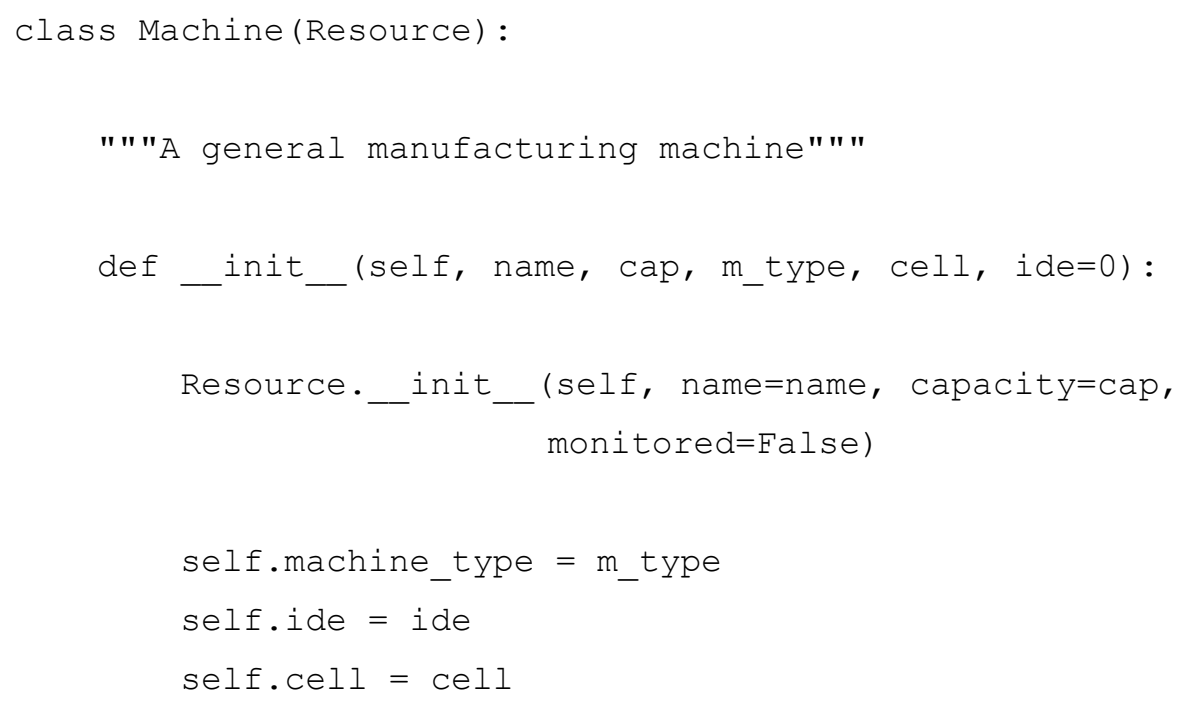

Quadro 11. Definição em Python da classe "máquina" com o uso do módulo SimPy

\subsubsection{Algoritmo genético}

O algoritmo genético foi implementado na linguagem $\mathrm{C}++$, com o uso da biblioteca Galib 2.4.6, desenvolvida no Massachusetts Institute of Technology (MIT) por Wall (1996). Essa biblioteca contém um conjunto de classes (templates) com os principais tipos de representação genética, operadores e algoritmos. Utiliza apenas C++ padrão, sendo portanto multiplataforma.

A biblioteca GAlib foi inicialmente projetada para o desenvolvimento de algoritmos genéticos com apenas uma função-objetivo. Foi necessário então derivar uma classe para o algoritmo genético implementado, baseado no NSGA-II, e o operador de seleção por torneio crowding. Foram também implementadas funções para o cálculo da dominância de Pareto, ranqueamento de Pareto, e cálculo da distância de crowding. 
6.5.3 Integração do modelo de simulação com o algoritmo genético

Para fazer a integração entre o AG implementado na linguagem C++ e o modelo de simulação, implementado em Python, foi usada uma biblioteca em $\mathrm{C}++$ chamada Boost.Python, versão 1.34.1. Essa biblioteca permite a exposição de uma interface para a linguagem Python, de forma que classes e funções implementadas em C++ possam ser acessadas a partir de código da linguagem Python. Boost.Python também permite o caminho inverso, ou seja, utilizar código em Python dentro de aplicações desenvolvidas em C++. Isso é possível por meio da incorporação de um interpretador da linguagem Python dentro da aplicação em C++. Essa alternativa foi a escolhida para implementação.

A Figura 32 exibe o relacionamento entre o AG e o modelo de simulação escrito em Python. O AG instancia um interpretador Python em sua rotina de inicialização. Cada vez que o AG precisa avaliar uma solução, o mesmo transfere o controle da execução para o interpretador juntamente com as informações da solução. Este então chama um script Python, o qual se encontra em um arquivo, e executa a simulação, retornando informações quanto às medidas de desempenho para o AG. 


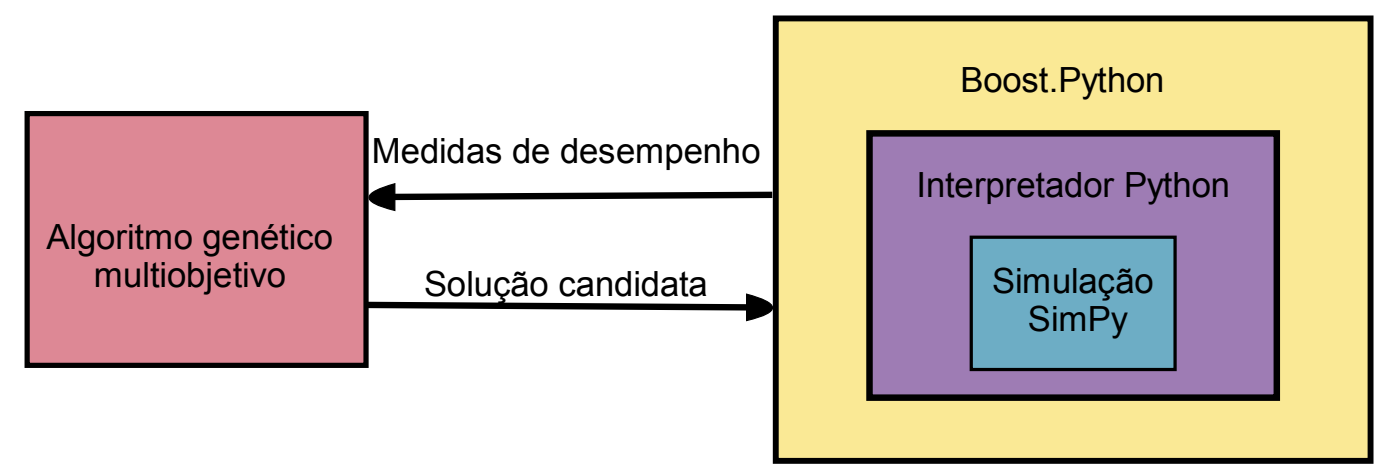

Figura 32. O algoritmo genético passa ao simulador a solução candidata, o qual retorna os valores das funções-objetivo (medidas de desempenho)

A aplicação desenvolvida é, portanto, um híbrido de C++ e Python, a qual foi chamada de "OptSim", e compilada no ambiente Microsoft Visual C++ 2005 express. Seu funcionamento se dá por meio da leitura de arquivos de entrada e configuração, e a geração de arquivos de saída. A Figura 33 exibe um exemplo do arquivo de configuração, e a Figura 34 exibe uma tela da execução em modo texto da aplicação desenvolvida.

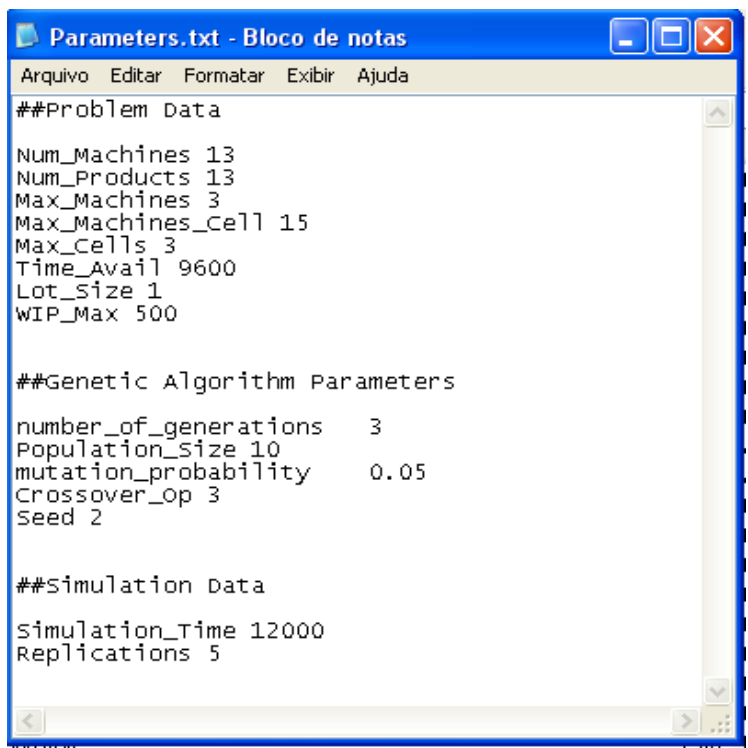

Figura 33. Arquivo de configuração do OptSim 


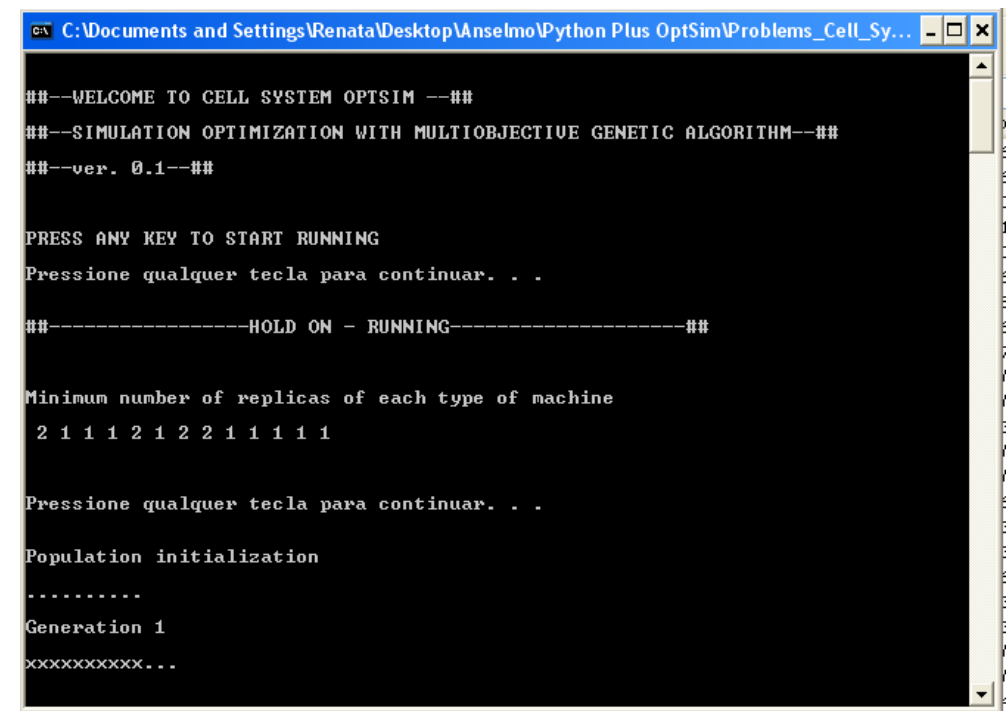

Figura 34. Tela de execução do OptSim

\subsubsection{Procedimento de redução da população final}

O algoritmo para redução do tamanho da população final foi implementado como um programa independente, e não integrado com o OptSim. Utilizou-se as funções da biblioteca C Clustering Library 1.37, desenvolvida na Universidade de Tóquio (DE HOON; IMOTO; MIYANO, 2007). A biblioteca oferece um conjunto de algoritmos para clusterização de dados na linguagem de programação C. Utilizaram-se as funções para clusterização por ALC, para cálculo de centróide e para o cálculo das soluções com menor distância ao centróide. O programa lê um arquivo com os vetores objetivos da população final, e retorna os índices das soluções selecionadas.

\subsection{Considerações finais}

Neste capítulo foi apresentado o modelo híbrido proposto para formação de células de manufatura. Seu esquema geral é sintetizado por meio da integração 
de um modelo de simulação de eventos discretos a um algoritmo genético multiobjetivo. O algoritmo genético realiza uma busca no espaço de soluções para o sistema celular, e atribui uma medida de adequação a cada solução por meio da simulação.

Descreveram-se o modelo de simulação de eventos discretos criado para representar um sistema de manufatura celular, juntamente com sua implementação por meio do módulo SimPy da linguagem Python, e o algoritmo genético multiobjetivo baseado no NSGA-II, implementado por classes da biblioteca GAlib em C++. A integração dos dois foi realizada com o uso da biblioteca Boost.Python, que permite o desenvolvimento de aplicações híbridas com C++ e Python.

No próximo capítulo, o modelo proposto é aplicado ilustrativamente a dois problemas-teste da literatura, e discutem-se os resultados obtidos. 


\section{EXPERIMENTAÇÕES E RESULTADOS}

Para validar o modelo proposto para a formação de células de manufatura, duas instâncias de problemas conhecidos da literatura foram selecionadas e submetidas ao processo de otimização. Os problemas são descritos nas seções seguintes. O objetivo não é comparar diretamente a qualidade dos resultados obtidos, visto que os autores considerados aplicam modelos com premissas diferentes, mas investigar o potencial do modelo proposto para a solução do problema de formação de células de manufatura.

\subsection{Problema-teste 1}

O primeiro problema considerado é uma adaptação do problema abordado por Wu (1998). Em seu artigo, o autor descreve o problema de formação de células de manufatura com múltiplas réplicas de máquinas, propondo um método gráfico baseado na Teoria dos Grafos para a sua solução, com o objetivo de minimizar a movimentação intercelular. Apesar do método ser eficaz, sua escalabilidade é limitada, pois se torna logo inviável para problemas grandes.

Wu seleciona três instâncias do problema. Será utilizada neste trabalho a maior das instâncias, visto que seu tamanho aproxima-se de aplicações reais.

A instância consiste em 13 tipos de máquinas diferentes e 13 produtos que devem ser fabricados pelas respectivas máquinas. Dispõe-se das demandas mensais de cada produto, de suas seqüências de fabricação, e dos tempos necessários em cada tipo de máquina.

A Tabela 9 exibe as demandas e seqüências de fabricação, enquanto a 
Tabela 10 exibe os tempos médios de processamento de cada produto em cada tipo de máquina.

Tabela 9 - Seqüências de fabricação e demandas dos produtos

\begin{tabular}{|c|c|c|c|}
\hline Produto & $\begin{array}{c}\text { Seqüência de } \\
\text { fabricaçãa (tipo de } \\
\text { máquina) }\end{array}$ & $\begin{array}{l}\text { Demanda mensal } \\
\text { média }\end{array}$ & $\begin{array}{c}\text { Percentual da } \\
\text { demanda total (\%) }\end{array}$ \\
\hline P1 & 58591213 & 400 & 7,43 \\
\hline P2 & 127 & 310 & 5,76 \\
\hline P3 & 589121389 & 1250 & 23,23 \\
\hline P4 & 267 & 350 & 6,51 \\
\hline P5 & 1581011 & 180 & 3,35 \\
\hline P6 & 3410 & 120 & 2,23 \\
\hline P7 & 3585 & 200 & 3,72 \\
\hline P8 & 141 & 1100 & 20,45 \\
\hline P9 & 1341011 & 430 & 7,99 \\
\hline P10 & 12467 & 280 & 5,2 \\
\hline P11 & 5851213 & 520 & 9,67 \\
\hline P12 & 31011 & 150 & 2,79 \\
\hline $\mathrm{P} 13$ & 1727 & 90 & 1,67 \\
\hline Total & - & 5380 & 100 \\
\hline
\end{tabular}

Inicialmente, foi calculado o número mínimo de réplicas de máquina para cada tipo de máquina. O resultado é exibido na Tabela 11. 
Tabela 10 - Tempos de processamento dos produtos em cada máquina (minutos). Adaptado de Wu (1998)

\begin{tabular}{cccccccccccccc}
\hline & \multicolumn{11}{c}{ Prod. } & \multicolumn{11}{c}{1} & 2 & 3 & 4 & 5 & 6 & 7 & 8 & 9 & 10 & 11 & 12 & 13 \\
\hline P1 & 0 & 0 & 0 & 0 & 7,2 & 0 & 0 & 7,2 & 4,8 & 0 & 0 & 7,2 & 4,8 \\
P2 & 10,84 & 4,65 & 0 & 0 & 0 & 0 & 7,74 & 0 & 0 & 0 & 0 & 0 & 0 \\
P3 & 0 & 0 & 0 & 0 & 4,61 & 0 & 0 & 1,92 & 2,3 & 0 & 0 & 1,92 & 3,84 \\
P4 & 0 & 4,11 & 0 & 0 & 0 & 6,86 & 12,34 & 0 & 0 & 0 & 0 & 0 & 0 \\
P5 & 2,67 & 0 & 0 & 0 & 10,67 & 0 & 0 & 10,67 & 0 & 16 & 10,67 & 0 & 0 \\
P6 & 0 & 0 & 16 & 16 & 0 & 0 & 0 & 0 & 0 & 8 & 0 & 0 & 0 \\
P7 & 0 & 0 & 4,8 & 0 & 14,4 & 0 & 0 & 31,2 & 0 & 0 & 0 & 0 & 0 \\
P8 & 2,84 & 0 & 0 & 2,18 & 0 & 0 & 0 & 0 & 0 & 0 & 0 & 0 & 0 \\
P9 & 4,47 & 0 & 4,47 & 3,35 & 0 & 0 & 0 & 0 & 0 & 4,47 & 6,7 & 0 & 0 \\
P10 & 13,7 & 13,7 & 0 & 3,43 & 0 & 13,7 & 27,4 & 0 & 0 & 0 & 0 & 0 & 0 \\
P11 & 0 & 0 & 0 & 0 & 2,77 & 0 & 0 & 2,77 & 0 & 0 & 0 & 2,77 & 0,92 \\
P12 & 0 & 0 & 19,2 & 0 & 0 & 0 & 0 & 0 & 0 & 12,8 & 19,2 & 0 & 0 \\
P13 & 16 & 10,7 & 0 & 0 & 0 & 0 & 16 & 0 & 0 & 0 & 0 & 0 & 0 \\
\hline
\end{tabular}

Tabela 11 - Número mínimo de réplicas por tipo de máquina

\begin{tabular}{|c|c|c|c|c|c|c|c|c|c|c|c|c|c|}
\hline & \multicolumn{12}{|c|}{ Tipo de máquina } & \multirow{2}{*}{ - Total } \\
\hline & 1 & 2 & 3 & 4 & 5 & 6 & 7 & 8 & 9 & 10 & 111 & 1213 & \\
\hline $\begin{array}{l}\text { Número mínimo } \\
\text { de réplicas }\end{array}$ & 2 & 1 & 1 & 1 & 2 & 1 & 2 & 2 & 1 & 1 & 1 & 1 & 17 \\
\hline
\end{tabular}

Executou-se o algoritmo proposto com os parâmetros listados nas tabelas 12,13 e14.

Tabela 12 - Parâmetros do algoritmo genético aplicado ao problema-teste 1

\begin{tabular}{lc}
\hline \multicolumn{1}{c}{ Parâmetro } & Valor adotado \\
\hline Número de gerações & 50 \\
Tamanho da população & 50 \\
Probabilidade de crossover & 1 \\
Probabilidade de Mutação & 0,05 \\
Semente & 2 \\
\hline
\end{tabular}


Tabela 13 - Parâmetros da simulação aplicada ao problema-teste 1

\begin{tabular}{lc}
\hline \multicolumn{1}{c}{ Parâmetro } & Valor adotado \\
\hline Tempo simulado (minutos) & 9600 \\
$\begin{array}{l}\text { Tempo de aquecimento } \\
\text { (minutos) }\end{array}$ & 2400 \\
Número de replicações & 5 \\
\hline
\end{tabular}

Tabela 14 - Parâmetros de projeto utilizados no problema-teste 1

\begin{tabular}{lc}
\hline \multicolumn{1}{c}{ Parâmetro } & Valor adotado \\
\hline $\begin{array}{l}\text { Número de células } \\
\text { Número máximo de máquinas por célula }\end{array}$ & 3 \\
$\begin{array}{l}\text { Número máximo de máquinas do mesmo } \\
\text { tipo em uma célula }\end{array}$ & 3 \\
$\begin{array}{l}\text { Custo unitário por réplica de máquina } \\
\text { Tempo disponível em uma máquina por }\end{array}$ & 10 \\
$\begin{array}{l}\text { unidade de tempo (minutos por mês) } \\
\text { Tamanho de lote }\end{array}$ & 9600 \\
$\begin{array}{l}\text { Máximo inventário em processo } \\
\text { admissível }\end{array}$ & 1 \\
\hline
\end{tabular}

Foram realizadas, no total, 2550 simulações, com tempo de execução de aproximadamente 8 horas em uma máquina Pentium $4 \mathrm{HT}$ com clock de $3 \mathrm{GHz}$ e memória RAM de 1 Gbyte.

Após a execução do algoritmo, a população de 50 soluções representa uma aproximação da fronteira ótima de Pareto. Os Gráficos 4, 5 e 6 apresentam a evolução dos valores das funções-objetivo ao longo da execução do algoritmo. Pode-se observar que há uma redução gradativa nas três funções ao longo da evolução do algoritmo genético. 


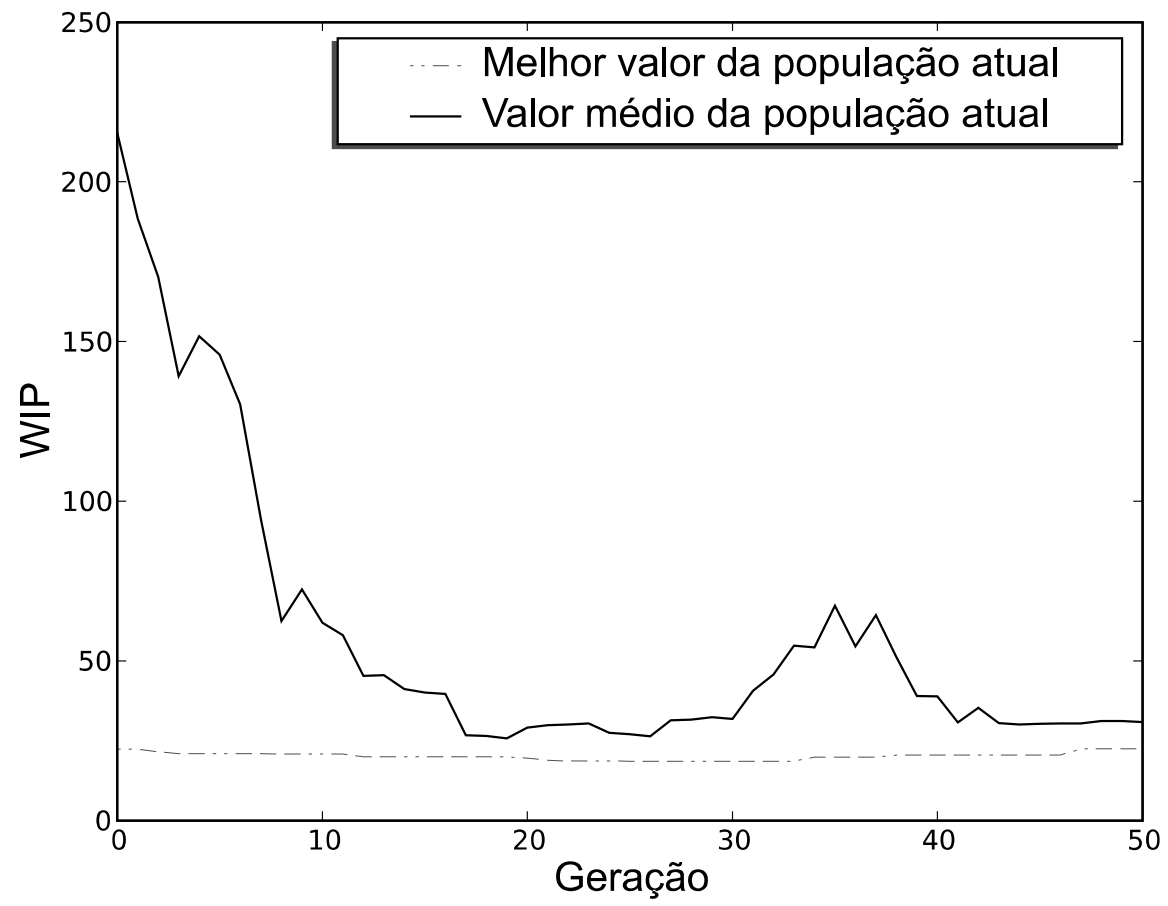

Gráfico 4. Evolução da função-objetivo "inventário em processo" ao longo das gerações

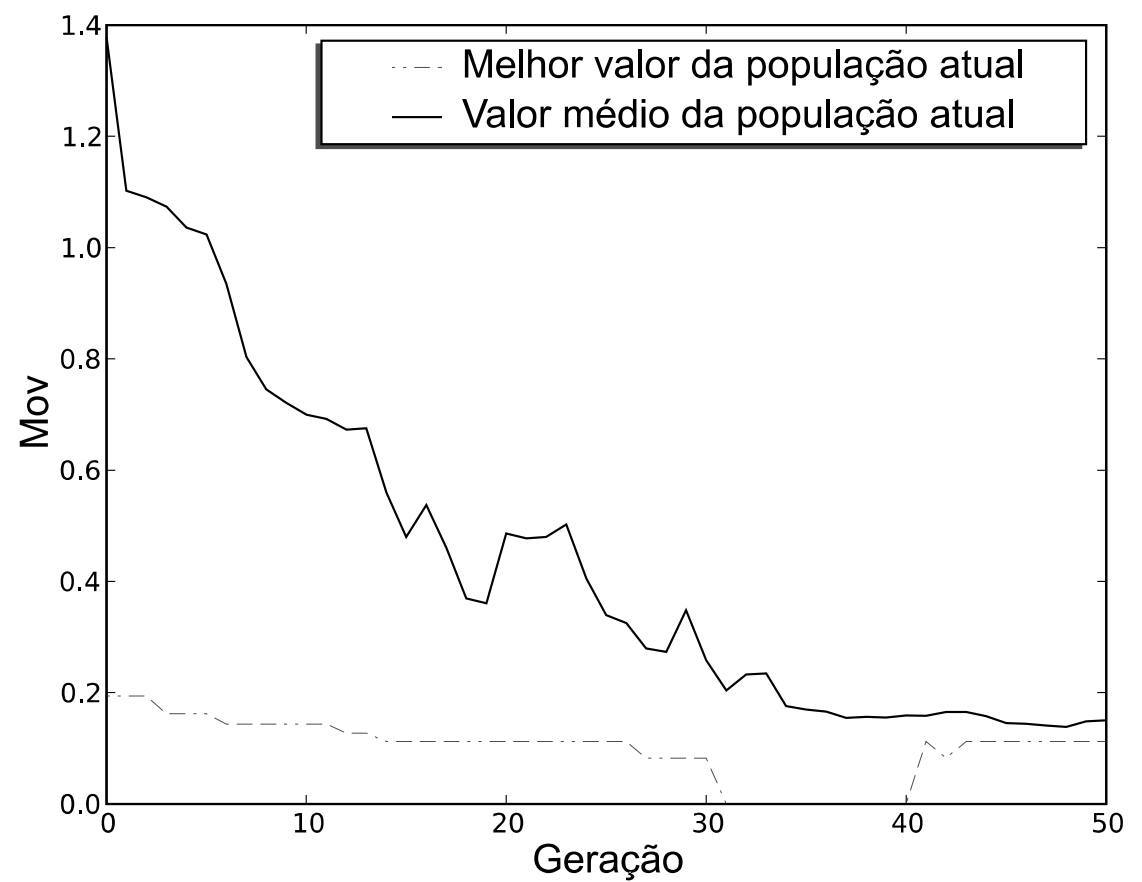

Gráfico 5. Evolução da função-objetivo "movimentação intercelular" ao longo das gerações 


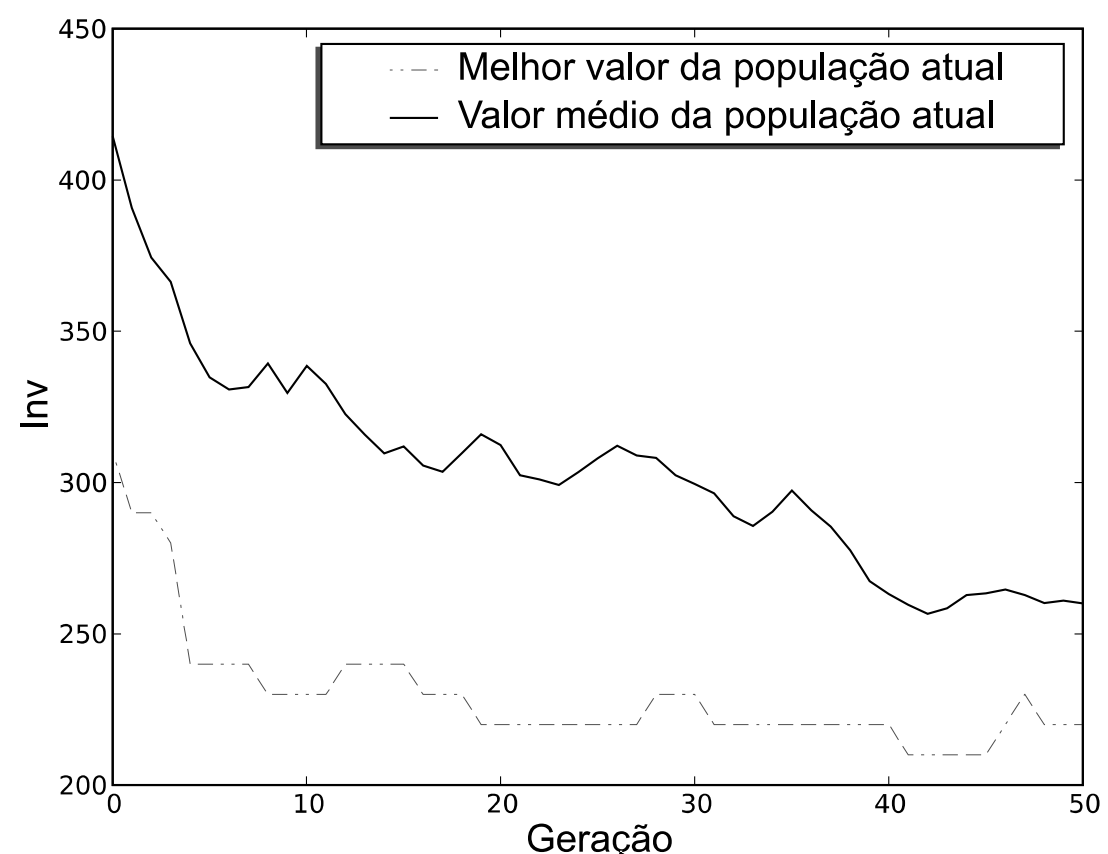

Gráfico 6. Evolução da função-objetivo "investimento em máquinas" ao longo das gerações

O Gráfico 4 indica que há uma queda rápida no valor médio de WIP até a $20^{a}$ geração. Depois há uma estabilização até a $30^{a}$ geração, quando ocorre um pico no valor médio, o qual se desfaz na 40ª geração. Observando-se o Gráfico 5, o qual exibe a evolução da movimentação intercelular média, nota-se que entre a $30^{\underline{a}}$ e $40^{\underline{a}}$ gerações o melhor valor na população é zero, período coincidente com o pico de WIP. A explicação, obtida a partir da análise dos valores objetivos individuais no período, é a de que alguns indivíduos que apresentam movimentação intercelular zero ou muito pequena têm desempenho muito ruim em termos de WIP, e inflacionam a média populacional. O fato do valor médio de WIP retornar a valores baixos evidencia a capacidade do algoritmo genético de se recuperar de regiões de baixo desempenho ou de ótimos locais.

O Gráfico 5 exibe a evolução da movimentação intercelular. Aqui já se observa uma inclinação menor da redução do valor médio, e maiores ganhos no 
valor mínimo, estabilizando-se por volta da $40^{\mathrm{a}}$ geração.

Por fim, o Gráfico 6 apresenta a evolução do investimento em máquinas. O valor mínimo cai rápido até a $10^{\mathrm{a}}$ geração, e então apresenta melhorias mais modestas. $O$ valor médio cai continuamente ao longo das 50 gerações, sem atingir um patamar. Isso indica que melhores soluções podem ser obtidas com a execução do algoritmo por um número maior de gerações.

O Gráfico 7 exibe a evolução do valor médio das três funções-objetivo no espaço tridimensional. Observa-se que há diminuição simultânea nas três medidas de desempenho à medida que o algoritmo se aproxima da fronteira de Pareto. Isso evidencia o potencial do algoritmo em buscar aproximações das soluções ótimas.

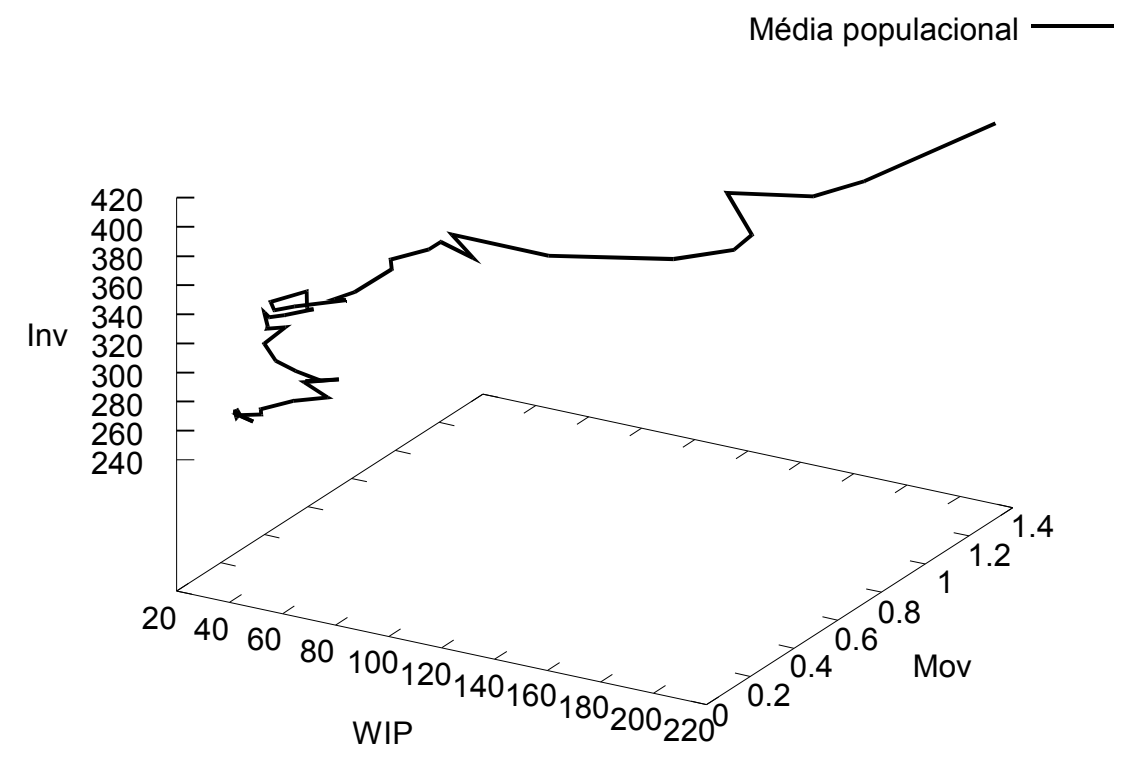

Gráfico 7. Evolução do valor médio populacional das 3 funções-objetivo em direção a menores valores do problema 1

O Gráfico 8 exibe a população inicial gerada e a população final, a qual corresponde à aproximação da fronteira de Pareto. 


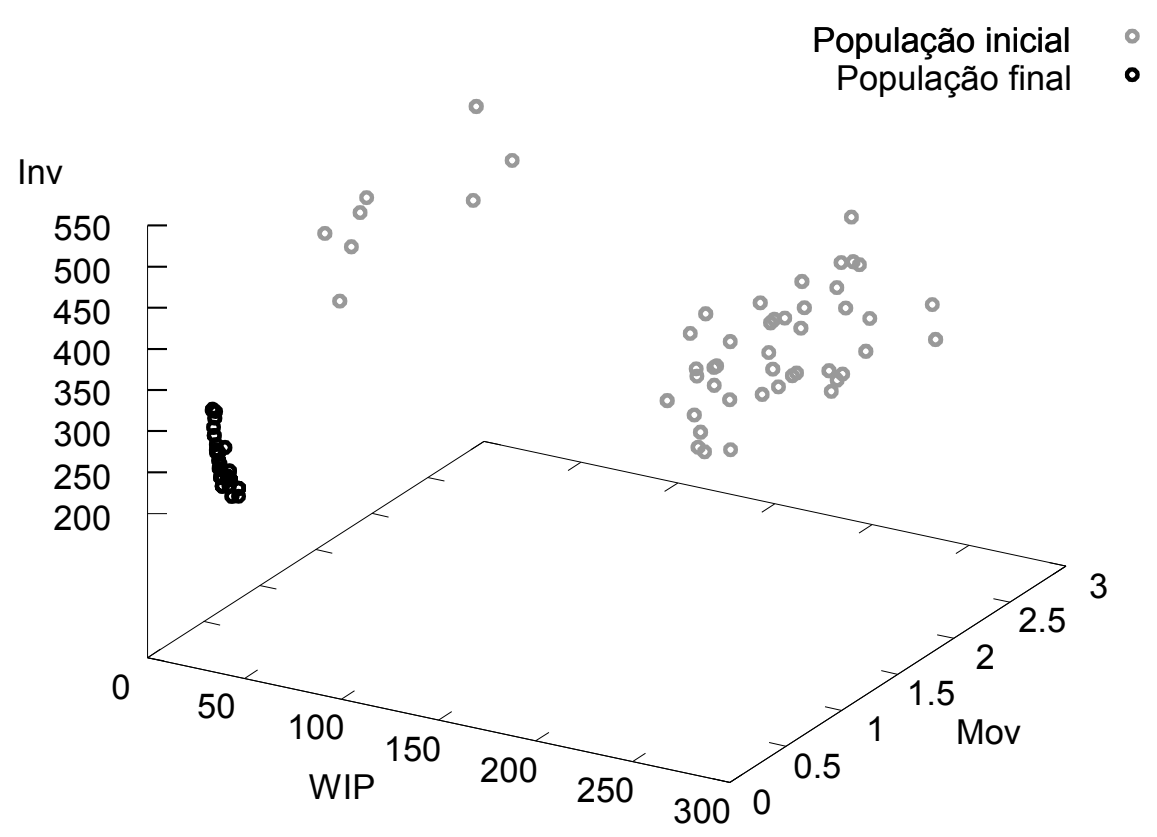

Gráfico 8. População inicial e aproximação da fronteira de Pareto no problema 1

Aplicou-se o ALC aos 50 vetores objetivos obtidos para o problema de Wu, formando-se cinco clusters. Selecionaram-se então as cinco soluções mais próximas de cada um dos centróides dos cinco clusters formados. A Tabela 15 exibe os vetores objetivo das cinco soluções obtidas.

Tabela 15 - Soluções não-dominadas obtidas pela redução da fronteira de Pareto aproximada. Os campos sombreados representam o melhor valor do respectivo objetivo

\begin{tabular}{cccc}
\hline Solução & $\begin{array}{c}\text { Inventário médio em } \\
\text { processo (WIP) - } \\
\text { (unidades de peças) }\end{array}$ & $\begin{array}{c}\text { Movimentação } \\
\text { intercelular média (Mov) } \\
- \text { (número de } \\
\text { movimentações) }\end{array}$ & $\begin{array}{c}\text { Investimento em } \\
\text { máquinas (Inv) - } \\
\text { (unidades monetárias) }\end{array}$ \\
\hline 1 & 23,34 & 0,1930 & 290 \\
2 & 24,30 & 0,1886 & 320 \\
3 & 34,68 & 0,2124 & 230 \\
4 & 28,14 & 0,1272 & 280 \\
5 & 32,11 & 0,1123 & 250 \\
\hline
\end{tabular}

A partir da Tabela 15 observa-se que as 5 soluções são de fato não- 
dominadas, pois nenhuma delas é melhor que qualquer outra nos três objetivos. Ou seja, representam trade-offs entre os objetivos.

A Tabela 15 ressalta com sombreamento em cinza os melhores valores para os respectivos objetivos. Observa-se que a solução 1 tem o menor inventário médio em processo, com valor de 23,34 unidades de peça em média. A solução 5 tem a menor movimentação intercelular média, com 0,1123 movimentações intercelulares. Como a movimentação é medida em números inteiros, isso significa que em média a maior parte das peças foram inteiramente processadas dentro da mesma célula, com eventualmente algumas peças roteadas para outras células, incorrendo em uma ou mais movimentações intercelulares. Por fim, a solução 3 tem o menor investimento em máquinas, medido em unidades monetárias, lembrando que adotou-se aqui o valor de 10 unidades monetárias para o custo (ou investimento) em uma réplica de qualquer tipo de máquina. As soluções 2 e 4 apresentam valores intermediários, e podem ser consideradas boas soluções de compromisso entre os três objetivos.

Dispondo das cinco soluções, a equipe responsável pelo projeto do sistema de manufatura celular pode se basear em regras simples de decisão, ou utilizar uma técnica de decisão multicritério mais sofisticada, para selecionar a solução definitiva.

O Gráfico 9 exibe as cinco soluções no espaço-objetivo obtidas após a clusterização. Pode-se observar que as soluções selecionadas são uma amostra representativa da população final. 


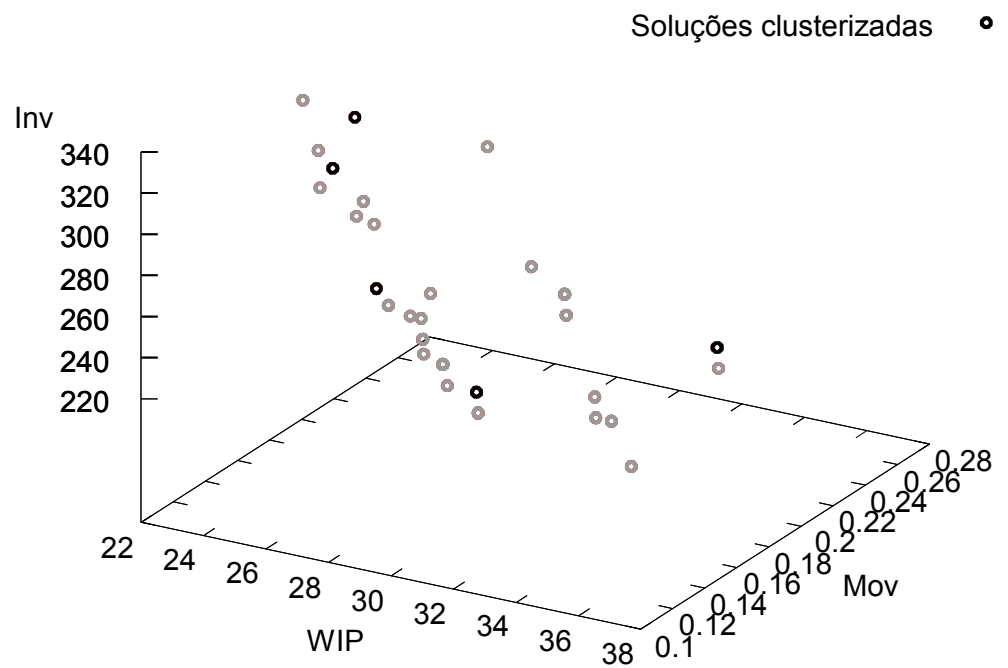

Gráfico 9. As soluções do problema 1 obtidas após a clusterização por ALC estão realçadas em preto

As Figuras 35 a 39 exibem cada uma das cinco soluções não-dominadas

finais.

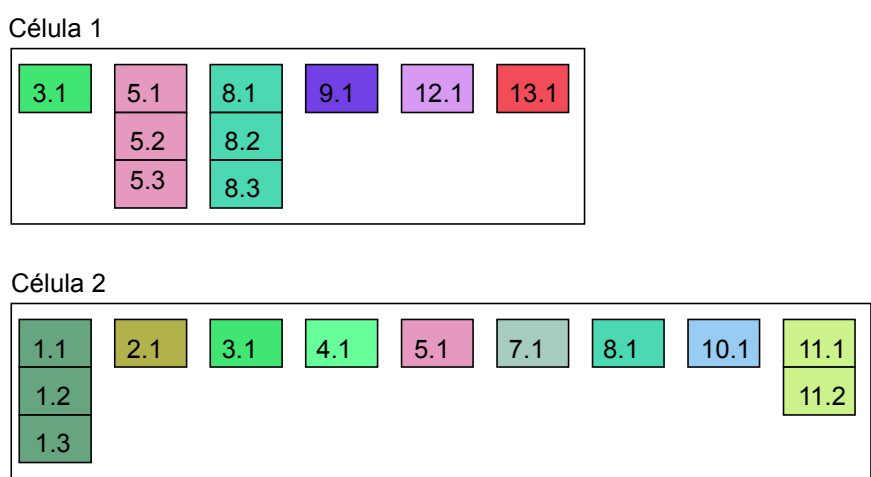

Célula 3

\begin{tabular}{|l|l|l|l|l|}
\hline 2.1 & 4.1 & 6.1 & 7.1 & 10.1 \\
\hline 4 & & 7.2 \\
\hline
\end{tabular}

WIP $=23.4$

Mov $=0.1930$

Inv $=290$

Figura 35. Solução não-dominada 1 para o problema-teste 1 
Célula 1

\begin{tabular}{|l|l|l|l|l|l|l|}
\hline 3.1 & 5.1 & 8.1 & 9.1 & 12.1 & 13.1 \\
\hline 5.2 & 8.2 & 9.2 \\
\hline 5.3 & 8.3 & 9.3 \\
\hline
\end{tabular}

Célula 2

\begin{tabular}{|c|c|c|c|c|c|c|c|c|}
\hline 1.1 & 2.1 & 3.1 & 4.1 & 5.1 & 7.1 & 8.1 & 10.1 & 11.1 \\
\hline 1.2 & & & & & & & & \\
\hline 1.3 & & & & & & & & \\
\hline
\end{tabular}

Célula 3

\begin{tabular}{|c|c|c|c|c|}
\hline 1.1 & 2.1 & 4.1 & 6.1 & 7.1 \\
\hline 1.2 & & 4.2 & & 7.2 \\
\hline 1.3 & & & & \\
\hline
\end{tabular}

$\mathrm{WIP}=24.3$

Mov $=0.1886$

Inv $=320$

Figura 36. Solução não-dominada 2 para o problema-teste 1

Célula 1

\begin{tabular}{|c|c|c|c|c|}
\hline 5.1 & 8.1 & 9.1 & 12.1 & 13.1 \\
\hline 5.2 & 8.2 & & & \\
\hline 5.3 & 8.3 & & & \\
\hline
\end{tabular}

Célula 2

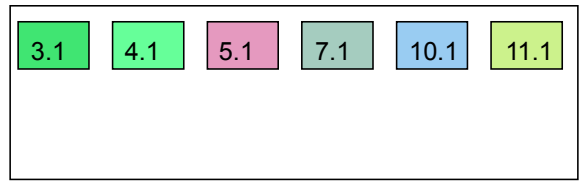

Célula 3

\begin{tabular}{|l|l|l|l|l|}
\hline 1.1 & 2.1 & 4.1 & 6.1 & 7.1 \\
\hline 1.2 & & & \\
\hline & & & \\
\hline & & & \\
\hline & & \\
\hline
\end{tabular}

$\mathrm{WIP}=34.68$

Mov $=0.2124$

$\operatorname{lnv}=230$

Figura 37. Solução não-dominada 3 para o problema-teste 1 
Célula 1

\begin{tabular}{|l|l|l|l|l|l|l|}
\hline 5.1 & 8.1 & 9.1 & 12.1 & 13.1 \\
\hline 5.2 & 8.2 & 9.2 & & \\
\hline 5.3 & 8.3 & 9.3 & \\
\hline
\end{tabular}

Célula 2

\begin{tabular}{|l|l|l|l|l|l|l|l|}
\hline 1.1 & 3.1 & 4.1 & 5.1 & 7.1 & 8.1 & 10.1 & 11.1 \\
\hline 1.2 & & & & & & & 11.2 \\
\hline 1.3 & & & & & & \\
\hline
\end{tabular}

Célula 3

\begin{tabular}{|l|l|l|l|}
\hline 2.1 & 4.1 & 6.1 & 7.1 \\
\hline 4.2 & & 7.2 \\
\hline
\end{tabular}

$\mathrm{WIP}=28.14$

Mov $=0.1272$

Inv $=280$

Figura 38. Solução não-dominada 4 para o problemateste 1

Célula 1
\begin{tabular}{|l|l|l|l|l|l|}
\hline 5.1 & 8.1 & 9.1 & 12.1 & 13.1 \\
\hline 5.2 & 8.2 & & \\
\hline 5.3 & 8.3 & \\
\hline
\end{tabular}

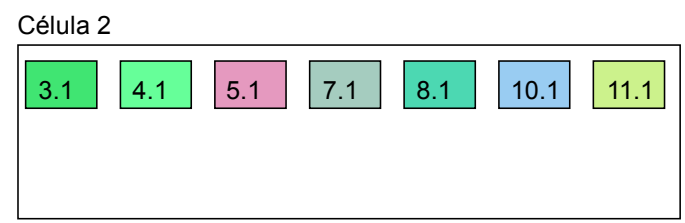

Célula 3
\begin{tabular}{|l|l|l|l|l|}
\hline 1.1 & 2.1 & 4.1 & 6.1 & 7.1 \\
\hline 1.2 & & 4.2 & & 7.2 \\
\hline 1.3 & & \\
\hline
\end{tabular}

WIP $=32.11$

Mov $=0.1123$

Inv $=250$

Figura 39. Solução não-dominada 5 para o problema-teste 1 
Alocação das peças às células

Para ilustrar como seriam criadas as famílias de peças a partir das células formadas, aplicaram-se as diretrizes sugeridas no item 2.7. A Tabela 16 indica a alocação de cada peça a uma célula de acordo com a solução não-dominada 5, e a Tabela 17 exibe as famílias formadas.

Tabela 16 - Alocação das peças às células

\begin{tabular}{lllccccc}
\hline & & \multicolumn{3}{c}{$\begin{array}{c}\text { Número de } \\
\text { operações }\end{array}$} & $\begin{array}{c}\text { Célula } \\
\text { Peça }\end{array}$ & $\begin{array}{c}\text { Seqüência de } \\
\text { fabricação }\end{array}$ & \multicolumn{3}{c}{\begin{tabular}{c} 
Máquinas na \\
\cline { 3 - 6 }
\end{tabular}} & $\begin{array}{c}\text { Célula } \\
\text { célula }\end{array}$ & $\begin{array}{c}\text { Célula } \\
\text { escolhidala escolhida }\end{array}$ & $\begin{array}{c}\text { Número de } \\
\text { operações } \\
\text { externas }\end{array}$ \\
\hline P1 & 58591213 & 5 & 2 & 0 & 1 & $5,8,9,12,13$ & 0 \\
P2 & 127 & 0 & 1 & 3 & 3 & $1,2,4,6,7$ & 0 \\
P3 & 589121389 & 5 & 2 & 0 & 1 & $5,8,9,12,13$ & 0 \\
P4 & 267 & 0 & 1 & 3 & 3 & $1,2,4,6,7$ & 0 \\
P5 & 1581011 & 2 & 4 & 0 & 2 & $3,4,5,7,8,10,11$ & 1 \\
P6 & 3410 & 0 & 3 & 1 & 2 & $3,4,5,7,8,10,11$ & 0 \\
P7 & 3585 & 2 & 3 & 0 & 2 & $3,4,5,7,8,10,11$ & 0 \\
P8 & 141 & 0 & 1 & 2 & 3 & $1,2,4,6,7$ & 0 \\
P9 & 1341011 & 0 & 4 & 2 & 2 & $3,4,5,7,8,10,11$ & 1 \\
P10 & 12467 & 0 & 2 & 5 & 3 & $1,2,4,6,7$ & 0 \\
P11 & 5851213 & 4 & 2 & 0 & 1 & $5,8,9,12,13$ & 0 \\
P12 & 31011 & 0 & 3 & 0 & 2 & $3,4,5,7,8,10,11$ & 0 \\
P13 & 1727 & 0 & 1 & 3 & 3 & $1,2,4,6,7$ & 0 \\
\hline
\end{tabular}

Tabela 17 - Famílias de peças formadas

\begin{tabular}{cl}
\hline Família / Célula & \multicolumn{1}{c}{ Peças } \\
\hline 1 & P1, P3, P11 \\
2 & P5, P6, P7, P9, P12 \\
3 & P2, P4, P8, P10, P13 \\
\hline
\end{tabular}


Simulação da solução obtida por Wu (1998)

A solução obtida por $\mathrm{Wu}$, com o objetivo de minimizar o movimento intercelular, é dada na Tabela 18:

Tabela 18 - Solução obtida por Wu (1998)

\begin{tabular}{cccccccccccccc}
\hline \multirow{2}{*}{ Célula } & \multicolumn{11}{c}{ Tipo de máquina } \\
\cline { 2 - 7 } & 1 & 2 & 3 & 4 & 5 & 6 & 7 & 8 & 9 & 10 & 11 & 12 & 13 \\
\hline 1 & 1 & 1 & 0 & 0 & 0 & 1 & 2 & 0 & 0 & 0 & 0 & 0 & 0 \\
2 & 0 & 0 & 0 & 0 & 2 & 0 & 0 & 1 & 1 & 0 & 0 & 1 & 1 \\
3 & 1 & 0 & 1 & 1 & 1 & 0 & 0 & 1 & 0 & 1 & 1 & 0 & 0 \\
\hline
\end{tabular}

A representação gráfica da solução obtida por Wu é exibida na Figura 40.

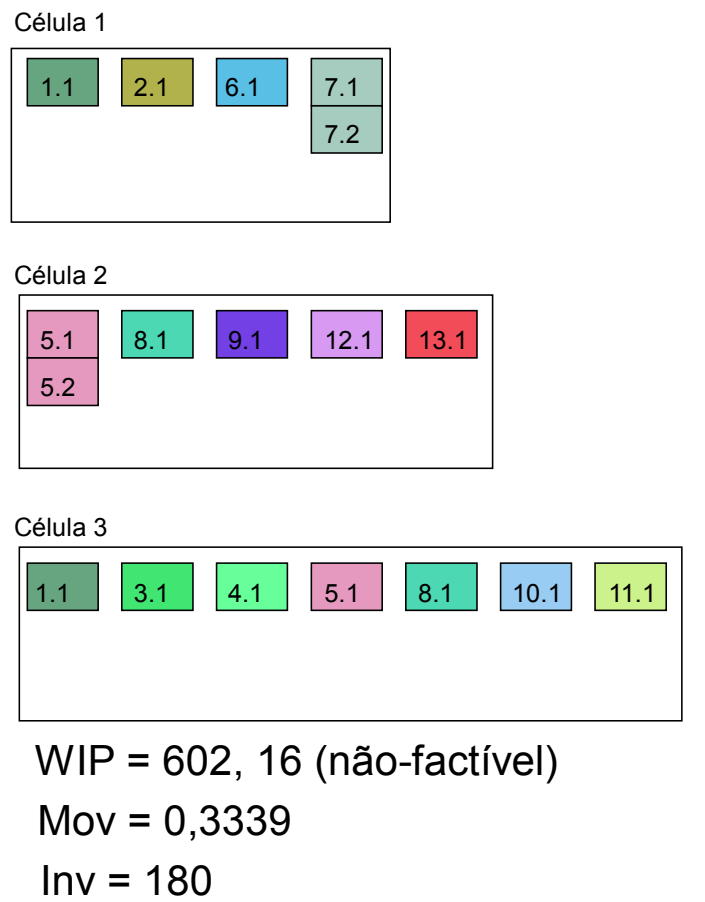

Figura 40. Representação gráfica da solução obtida por Wu (1998)

Simulou-se a solução obtida por Wu para se obter os valores de inventário 
em processo (WIP), movimentação intercelular (Mov) e número total de máquinas (Inv). Os parâmetros utilizados na simulação estão exibidos na Tabela 19.

Tabela 19 - Valores adotados para os parâmetros da simulação da solução obtida por Wu (1998)

\begin{tabular}{cc}
\hline Parâmetro & Valor adotado \\
\hline Tempo de simulação & 9600 minutos \\
Tempo de aquecimento & 2400 minutos \\
Número de replicações & 30 \\
\hline
\end{tabular}

Os resultados obtidos estão exibidos naTabela 20.

Tabela 20 - Resultados da simulação da solução obtida por Wu (1998)

\begin{tabular}{lccc}
\hline \multicolumn{1}{c}{ Função objetivo } & Média & Desvio-padrão & $\begin{array}{c}\text { Intervalo de } \\
\text { confiança 95\% }\end{array}$ \\
\hline $\begin{array}{l}\text { Inventário em } \\
\text { processo (lotes) }\end{array}$ & 602,16 & 28,97 & {$[591,79 ; 612,53]$} \\
$\begin{array}{l}\text { Movimentação } \\
\text { intercelular por lote }\end{array}$ & 0,3339 & 0,008744 & {$[0,3308 ; 0,3370]$} \\
Investimento total & 180 & 0 & 0 \\
\hline
\end{tabular}

Observando a Tabela 20, atesta-se que o inventário em processo para a solução proposta por Wu é consideravelmente alto. De fato, comparando-se com a Tabela 15, verifica-se que se pôde obter inventário médio em processo menor que 50 lotes. Essa discrepância ocorre porque o autor não considerou o efeito de perda de agregação de variabilidade, o qual se manifesta quando "pools" de réplicas de máquinas são desfeitos e as mesmas agrupadas em células. Como o método usado pelo autor para o cálculo do número mínimo de máquinas não leva em conta esse efeito, a solução sugerida não atende à restrição básica de sistemas com filas, segundo a qual a taxa de serviço das máquinas no sistema deve ser estritamente maior que a taxa de chegada de pedidos demandados. Isso significa que algum 
procedimento para conter o acúmulo de inventário terá de ser implementado.

De fato, a solução de Wu possui valor de investimento menor que as cinco soluções não-dominadas obtidas, o que a faria também uma solução nãodominada. No entanto, a solução obtida por Wu se mostra operacionalmente nãofactível quando simulada pelo modelo de Simulação construído.

O Gráfico 10 exibe uma série temporal do inventário em processo ao longo de uma replicação. Pode-se observar que há o crescimento constante de inventário.

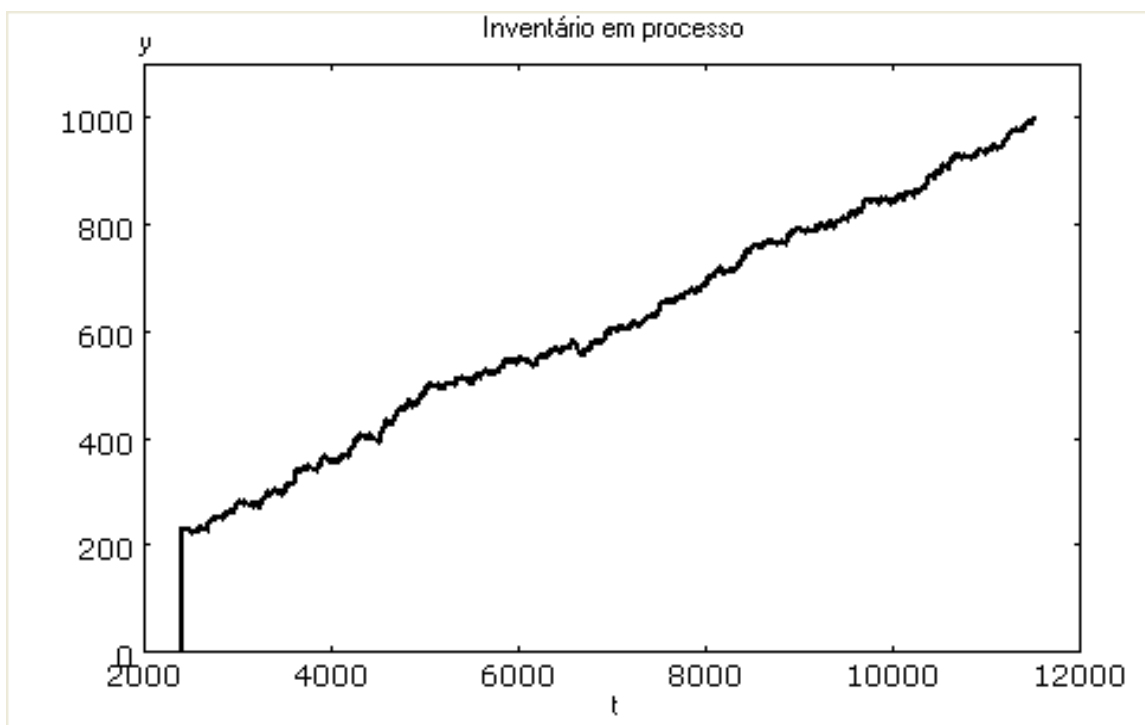

Gráfico 10. Inventário em processo aumenta progressivamente no sistema celular proposto por Wu (1998)

Observando-se as soluções não-dominadas obtidas pelo modelo proposto, verificam-se algumas semelhanças entre as mesmas e a solução obtida por Wu. A Figura 41 ilustra o fato mostrando a solução não-dominada 5 e a solução de Wu. 


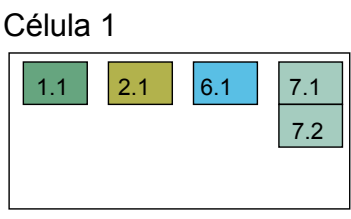

Célula 2

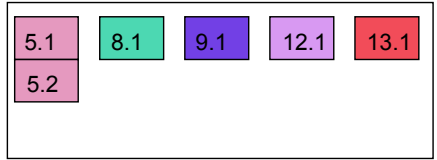

Célula 3

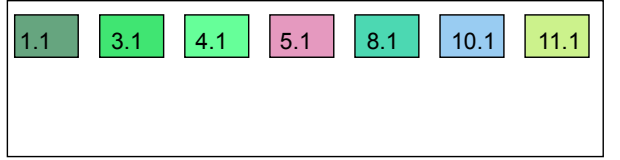

WIP $=602,16$ (não-factível)

Mov $=0,3339$

Inv $=180$
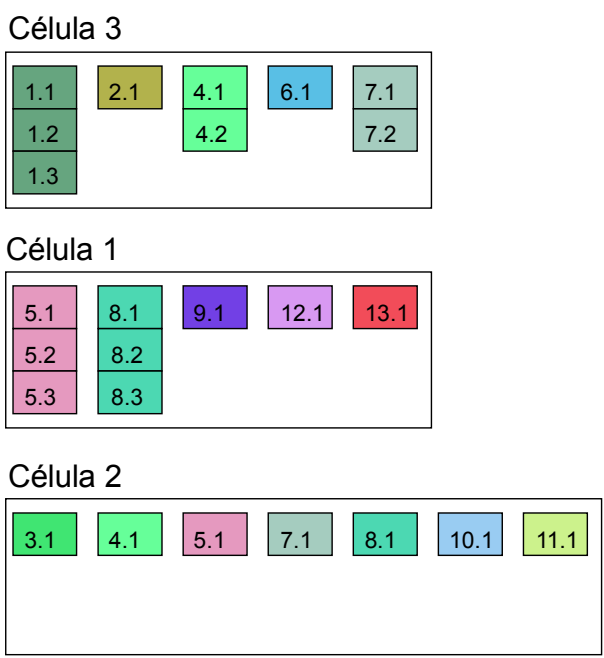

$$
\begin{aligned}
& \text { WIP }=32,11 \\
& \text { Mov }=0,1123 \\
& \operatorname{Inv}=250
\end{aligned}
$$

Figura 41. Comparação entre a solução de Wu e solução não-dominada 5 obtida

$\mathrm{Na}$ Figura 41, pode-se notar que a solução não-dominada 5 tem a composição de células ligeiramente diferente da solução de Wu. Especificamente, a célula 2 da solução de $W u$, e a célula 1 da solução obtida possuem a mesma composição em termos de tipos de máquinas, mas esta última possui uma réplica a mais da máquina do tipo 5 e duas réplicas a mais da máquina do tipo 8 . Quanto às outras células, há algumas diferenças quanto aos tipos de máquinas e número de réplicas. O maior número de réplicas na solução obtida pode ser a explicação para o seu melhor desempenho em WIP e Mov. De fato, a movimentação intercelular (Mov) é $66,37 \%$ menor na solução obtida. No entanto, o investimento é $38,80 \%$ maior.

É possível fazer a mesma análise com as outras soluções nãodominadas, constatando os trade-offs entre WIP, Mov e Inv. 
Simulação da solução de Wu considerada como um sistema de manufatura funcional

Considerou-se a solução obtida por Wu como um sistema de manufatura funcional com o propósito de avaliar o desempenho deste frente ao sistema celular. O arranjo físico funcional agrupa todas as réplicas do mesmo tipo de máquina em um mesmo departamento (ou célula). Dessa forma, todas as máquinas de um mesmo tipo compartilham a mesma fila, possibilitando agregação da variabilidade, o que resulta em redução de inventário em processo.

Simulou-se então um sistema de manufatura funcional com o número de máquinas adotado por Wu. Os resultados são exibidos na Tabela 21.

Tabela 21 - Resultados da simulação da solução obtida por Wu (1998) quando adaptada a um arranjo físico funcional

\begin{tabular}{lccc}
\hline \multicolumn{1}{c}{ Função objetivo } & Média & Desvio-padrão & $\begin{array}{c}\text { Intervalo de } \\
\text { confiança 95\% }\end{array}$ \\
\hline $\begin{array}{l}\text { Inventário em } \\
\text { processo (lotes) }\end{array}$ & 49,99 & 6,28 & {$[47,74 ; 52,24]$} \\
$\begin{array}{l}\text { Movimentação } \\
\text { intercelular por lote }\end{array}$ & 3,7319 & 0,02704 & {$[3,7222 ; 3,7416]$} \\
Investimento total & 180 & 0 & 0 \\
\hline
\end{tabular}

O Gráfico 11 exibe a evolução do inventário em processo ao longo do tempo em um sistema de manufatura funcional equivalente. Fica claro que o sistema atinge o estado estacionário e o inventário em processo, apesar de oscilar, permanece com valor médio constante. 


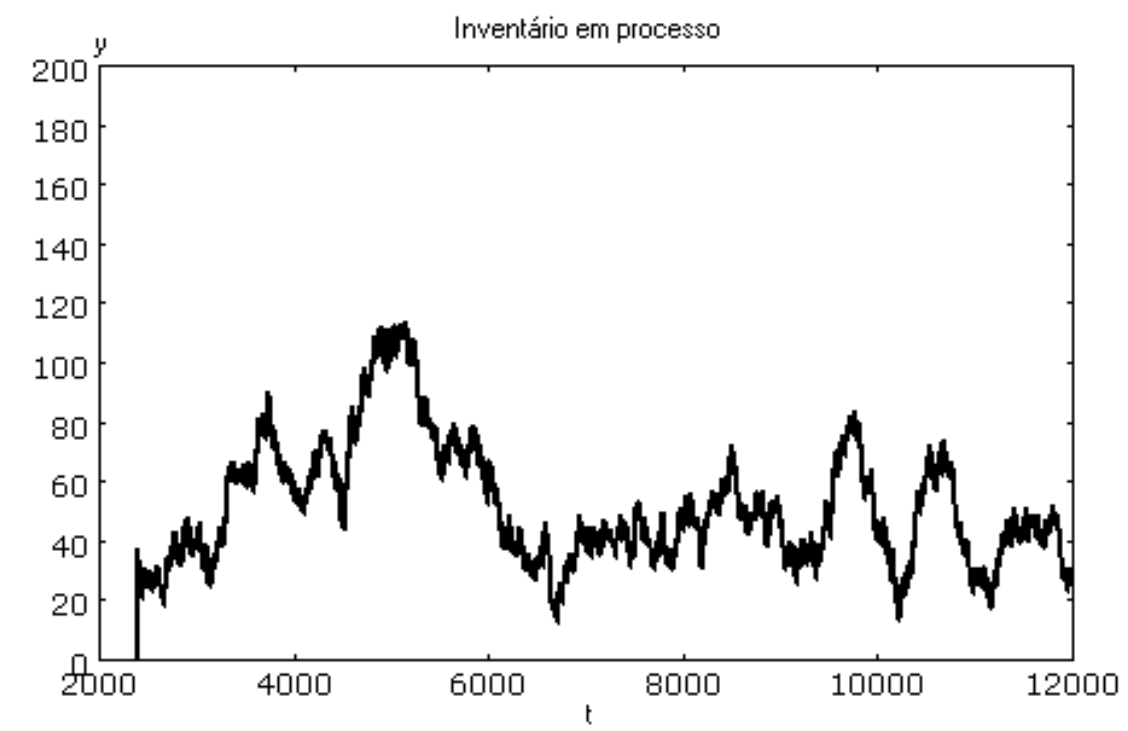

Gráfico 11. Inventário em processo em um sistema de manufatura funcional equivalente ao sistema celular proposto por Wu (1998)

O inventário médio obtido foi menor (49,99 lotes), que na simulação considerando-se um sistema celular $(602,16)$. Isso demonstra que a capacidade calculada é suficiente para um sistema funcional, em que a agregação de variabilidade é total, mas insuficiente para um sistema celular. Mesmo assim, todas as 5 soluções não-dominadas obtidas por meio do modelo proposto neste trabalho geraram inventário em processo menor que o valor obtido pelo sistema funcional (vide Tabela 15).

Considerando-se cada departamento do sistema de manufatura funcional como uma célula, em que todas as máquinas são de mesmo tipo, pode-se fazer referência à movimentação intercelular, a qual, neste caso, é consideravelmente pior (Mov $=3,7319)$ que nas soluções não-dominadas obtidas (Tabela 15). Na prática, essa alta movimentação intercelular (interdepartamental) exige maior capacidade do sistema de movimentação e maiores lotes de produção.

Os resultados acima indicam, portanto, que com um pouco mais de investimento é possível se obter reduções sensíveis de inventário e de 
movimentação intercelular.

\subsection{Problema-teste 2}

O segundo conjunto de dados utilizado foi adaptado do artigo de Venugopal e Narendran (1992). Nesse artigo, os autores descrevem o desenvolvimento e aplicação de um algoritmo genético para a solução do problema de formação de células de produção com dois objetivos: minimização da movimentação intercelular e minimização da variação da carga de trabalho dentro das células de manufatura.

Entre as instâncias do problema estudadas pelos autores, selecionou-se uma instância com 15 tipos de máquinas e 30 produtos diferentes. A Tabela 22 contém informações quanto à seqüência de fabricação dos produtos, enquanto a Tabela 23 contém os tempos de fabricação de cada produto em cada tipo de máquina. 
Tabela 22 - Seqüências de fabricação e demandas dos produtos (VENUGOPAL; NARENDRAN, 1992)

\begin{tabular}{|c|c|c|c|}
\hline Produto & $\begin{array}{l}\text { Seqüência de fabricação(tipo de } \\
\text { máquina) }\end{array}$ & $\begin{array}{l}\text { Demanda mensal } \\
\text { média }\end{array}$ & $\begin{array}{c}\text { Percentual da } \\
\text { demanda total (\%) }\end{array}$ \\
\hline $\mathrm{P} 1$ & 2371011 & 155 & 0.03384 \\
\hline $\mathrm{P} 2$ & 45689 & 150 & 0.03274 \\
\hline P3 & 12371011 & 148 & 0.03231 \\
\hline P4 & 31112131415 & 160 & 0.03493 \\
\hline P5 & 45689 & 144 & 0.03143 \\
\hline P6 & 123710 & 158 & 0.03449 \\
\hline P7 & 13710 & 152 & 0.03318 \\
\hline $\mathrm{P} 8$ & 123710 & 155 & 0.03384 \\
\hline P9 & 123710 & 164 & 0.03580 \\
\hline P10 & 123710 & 148 & 0.03231 \\
\hline $\mathrm{P} 11$ & 123710 & 140 & 0.03056 \\
\hline $\mathrm{P} 12$ & 5689 & 144 & 0.03143 \\
\hline P13 & 41112131415 & 145 & 0.03165 \\
\hline P14 & 45689 & 162 & 0.03536 \\
\hline P15 & 41112131415 & 170 & 0.03711 \\
\hline P16 & 345689 & 140 & 0.03056 \\
\hline $\mathrm{P} 17$ & 23710 & 156 & 0.03405 \\
\hline P18 & 145689 & 132 & 0.02882 \\
\hline P19 & 23710 & 172 & 0.03755 \\
\hline P20 & 145689 & 164 & 0.03580 \\
\hline P21 & 11121314 & 144 & 0.03143 \\
\hline P22 & 45689 & 158 & 0.03449 \\
\hline P23 & 1112131415 & 155 & 0.03383 \\
\hline P24 & 11121314 & 152 & 0.03318 \\
\hline P25 & 1112131415 & 140 & 0.03056 \\
\hline P26 & 45689 & 166 & 0.03623 \\
\hline $\mathrm{P} 27$ & 45689 & 148 & 0.03230 \\
\hline P28 & 1112131415 & 145 & 0.03165 \\
\hline P29 & 1112131415 & 144 & 0.03143 \\
\hline P30 & 1112131415 & 170 & 0.03710 \\
\hline Total & - & 4581 & 1 \\
\hline
\end{tabular}


Tabela 23 - Tempos de processamento dos produtos em cada máquina (minutos). Adaptado de Venugopal e Narendran (1992)

\begin{tabular}{|c|c|c|c|c|c|c|c|c|c|c|c|c|c|c|c|}
\hline \multirow{2}{*}{ Produto } & \multicolumn{15}{|c|}{ Tipo de máquina } \\
\hline & 1 & 2 & 3 & 4 & 5 & 6 & & 8 & 9 & 10 & 11 & 12 & 13 & 14 & 15 \\
\hline P1 & 0 & & & & & & & 0 & & & 3 & 0 & 0 & 0 & 0 \\
\hline P2 & 0 & 0 & 0 & 2 & 2 & $\varepsilon$ & & 11 & 4 & 0 & 0 & 0 & 0 & 0 & 0 \\
\hline & & & 7 & & & & & & & 2 & 3 & 0 & 0 & & 0 \\
\hline $\mathrm{P}$ & & 0 & 3 & & & c & & 0 & & & 2 & 6 & 7 & & 5 \\
\hline P5 & 0 & 0 & 0 & $=$ & 3 & c & & 12 & 5 & 0 & 0 & 0 & 0 & 0 & 0 \\
\hline P6 & 6 & 7 & 2 & 0 & 0 & 0 & & 0 & 0 & 3 & 0 & 0 & 0 & 0 & 0 \\
\hline P7 & & 3 & 4 & & & 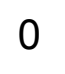 & & 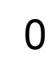 & & & 0 & 0 & 0 & 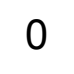 & 0 \\
\hline $\mathrm{P}$ & & 4 & 9 & & & 0 & & 0 & 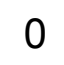 & 2 & 0 & 0 & 0 & 0 & 0 \\
\hline$P Q$ & 2 & 3 & 6 & 0 & 0 & 0 & & 0 & 0 & 3 & 0 & 0 & 0 & 0 & 0 \\
\hline P10 & 5 & 6 & 2 & 0 & 0 & 0 & & 0 & 0 & 4 & 0 & 0 & 0 & 0 & 0 \\
\hline$P$ & 7 & 8 & 2 & & 0 & 0 & & 0 & 0 & 5 & 0 & 0 & 0 & 0 & 0 \\
\hline & 0 & 0 & 0 & O & 4 & 10 & & 3 & 6 & 0 & 0 & 0 & 0 & 0 & 0 \\
\hline P13 & 0 & 0 & 0 & 4 & 0 & 0 & ( & 0 & 0 & 0 & 3 & 7 & 5 & 6 & 7 \\
\hline 14 & 0 & 0 & 0 & 7 & 5 & 7 & & 8 & 9 & 0 & 0 & 0 & 0 & 0 & 0 \\
\hline & 0 & 0 & 0 & & & & & & & & 4 & 8 & $\epsilon$ & & $\sigma$ \\
\hline P16 & 0 & 0 & 4 & 6 & 7 & 2 & & 3 & 5 & 0 & 0 & 0 & 0 & 0 & 0 \\
\hline P17 & 0 & 9 & 3 & 0 & 0 & 0 & & 0 & 0 & 6 & 0 & 0 & 0 & 0 & 0 \\
\hline & 4 & 0 & 0 & & $\varepsilon$ & & & $\sqrt{3}$ & 0 & 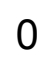 & 0 & 0 & 0 & 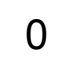 & 0 \\
\hline & 0 & 2 & & & 0 & 0 & & 0 & & 8 & 0 & 0 & 0 & 0 & 0 \\
\hline P20 & 6 & 0 & 0 & 4 & 9 & 4 & & 2 & 7 & 0 & 0 & 0 & 0 & 0 & 0 \\
\hline & 0 & 0 & 0 & 0 & 0 & 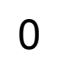 & & 0 & 0 & 0 & 5 & 9 & 8 & 10 & 0 \\
\hline & 0 & 0 & 0 & 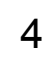 & 6 & 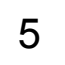 & & $\checkmark$ & 8 & 0 & 0 & 0 & 0 & 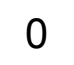 & 0 \\
\hline & 0 & 0 & 0 & & & & & 0 & 0 & 0 & 9 & 9 & 5 & 5 & 3 \\
\hline P24 & 0 & 0 & 0 & 0 & 0 & 0 & & 0 & 0 & 0 & 2 & 3 & 3 & 4 & 0 \\
\hline & 0 & 0 & 0 & 0 & 0 & 0 & 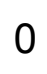 & 0 & 0 & 0 & 5 & 5 & 4 & 6 & 7 \\
\hline & 0 & 0 & 0 & & & & & 4 & 9 & 0 & 0 & 0 & 0 & 0 & 0 \\
\hline P27 & 0 & 0 & 0 & 6 & 2 & 8 & & 5 & 10 & 0 & 0 & 0 & 0 & 0 & 0 \\
\hline P28 & 0 & 0 & 0 & 0 & 0 & 0 & C & 0 & 0 & 0 & 6 & 5 & 5 & 8 & 9 \\
\hline & 0 & 0 & 0 & 0 & 0 & 0 & 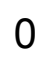 & 0 & 0 & 0 & 7 & 6 & 7 & 2 & 3 \\
\hline P30 & $\mathrm{c}$ & 0 & ( & & & & & 0 & 0 & 0 & 8 & 7 & 8 & 8 & \\
\hline
\end{tabular}

A Tabela 24 apresenta o número mínimo de réplicas pra cada tipo de 
máquina obtido por Venugopal e Narendran.

Tabela 24 - Número mínimo de réplicas por tipo de máquina para o problema abordado por Venugopal e Narendran (1992)

\begin{tabular}{|c|c|c|c|c|c|c|c|c|c|c|c|c|c|c|c|c|}
\hline & \multicolumn{15}{|c|}{ Tipo de máquina } & \multirow{2}{*}{ Total } \\
\hline & 1 & 2 & 3 & 4 & 5 & 6 & 7 & 8 & 9 & 10 & 11 & 12 & 13 & 14 & 15 & \\
\hline $\begin{array}{l}\text { Número } \\
\text { mínimo de } \\
\text { réplicas }\end{array}$ & 1 & 1 & 1 & 1 & 1 & 1 & 1 & 1 & 2 & 1 & 1 & 2 & 1 & 1 & 1 & 17 \\
\hline
\end{tabular}

As tabelas 25, 26 e 27 contêm os parâmetros utilizados na execução do algoritmo genético.

Tabela 25 - Parâmetros do algoritmo genético aplicado ao problema-teste 2

\begin{tabular}{lc}
\hline \multicolumn{1}{c}{ Parâmetro } & Valor adotado \\
\hline Número de gerações & 50 \\
Tamanho da população & 50 \\
Probabilidade de crossover & 1 \\
Probabilidade de Mutação & 0.05 \\
Semente & 2 \\
\hline
\end{tabular}

Tabela 26 - Parâmetros da simulação aplicada ao problema-teste 2

\begin{tabular}{cc}
\hline Parâmetro & Valor adotado \\
\hline Tempo simulado (minutos) & 12000 \\
Tempo de aquecimento (minutos) & 2400 \\
Número de replicações & 5 \\
\hline
\end{tabular}


Tabela 27 - Parâmetros de projeto utilizados no problema-teste 2

\begin{tabular}{lc}
\hline \multicolumn{1}{c}{ Parâmetro } & Valor adotado \\
\hline Número de células & 3 \\
$\begin{array}{l}\text { Número máximo de máquinas } \\
\text { por célula }\end{array}$ & 15 \\
$\begin{array}{l}\text { Número máximo de máquinas do } \\
\text { mesmo tipo em uma célula }\end{array}$ & 3 \\
$\begin{array}{l}\text { Custo unitário por réplica de } \\
\text { máquina }\end{array}$ & 10 \\
$\begin{array}{l}\text { Tempo disponível em uma } \\
\text { máquina (minutos por mês) }\end{array}$ & 9600 \\
$\begin{array}{l}\text { Tamanho de lote } \\
\text { Máximo inventário em processo } \\
\text { admissível }\end{array}$ & 1 \\
\hline
\end{tabular}

Foram realizadas, no total, 2550 simulações, com tempo de execução de aproximadamente 12 horas em uma máquina Pentium $4 \mathrm{HT}$ com clock de $3 \mathrm{GHz}$ e memória RAM de 1 Gbyte.

Os Gráficos 12, 13 e 14 exibem a evolução do WIP, Mov e Inv, respectivamente. Da mesma forma como no problema-teste 1 , há a diminuição gradativa dos valores médios e mínimos nas três funções-objetivo, mas não tão acentuada como no problema 1. Isso pode acontecer porque a instância do problema 2 é maior (30 produtos e 15 tipos de máquinas), e é necessário mais gerações para uma melhor convergência.

O Gráfico 12 exibe uma oscilação no WIP médio da população até aproximadamente a $25^{\mathrm{a}}$ geração, a partir da qual há uma redução até a $40^{\mathrm{a}}$ geração, estabilizando-se em um valor aproximadamente constante. O valor mínimo também apresenta reduções ao longo das gerações.

A movimentação intercelular média na população (Gráfico 13) passa por uma queda até a $25^{\mathrm{a}}$ geração, quando então apresenta certa oscilação até a $40^{\mathrm{a}}$ geração, quando então volta a diminuir. Mais uma vez, parece haver uma interação 
entre essas duas funções-objetivo, mas por uma razão diferente da apresentada no problema 1. Uma hipótese, neste caso, é a de que o algoritmo explorou primeiro os ganhos em movimentação, em detrimento do desempenho em WIP, e depois passou a explorar ganhos em WIP. O valor mínimo apresenta reduções até a $20^{a}$ geração, quando então se estabiliza em um valor praticamente constante.

Por fim, o Gráfico 14 exibe a evolução do Inv. Verifica-se a redução progressiva no seu valor médio até a $50^{a}$ geração, enquanto o valor mínimo experimenta uma redução acentuada até a $20^{\mathrm{a}}$ geração, a partir da qual há uma diminuição na taxa de redução. Mais uma vez observa-se que ganhos podem ser obtidos pela execução do algoritmo por um número maior de gerações.

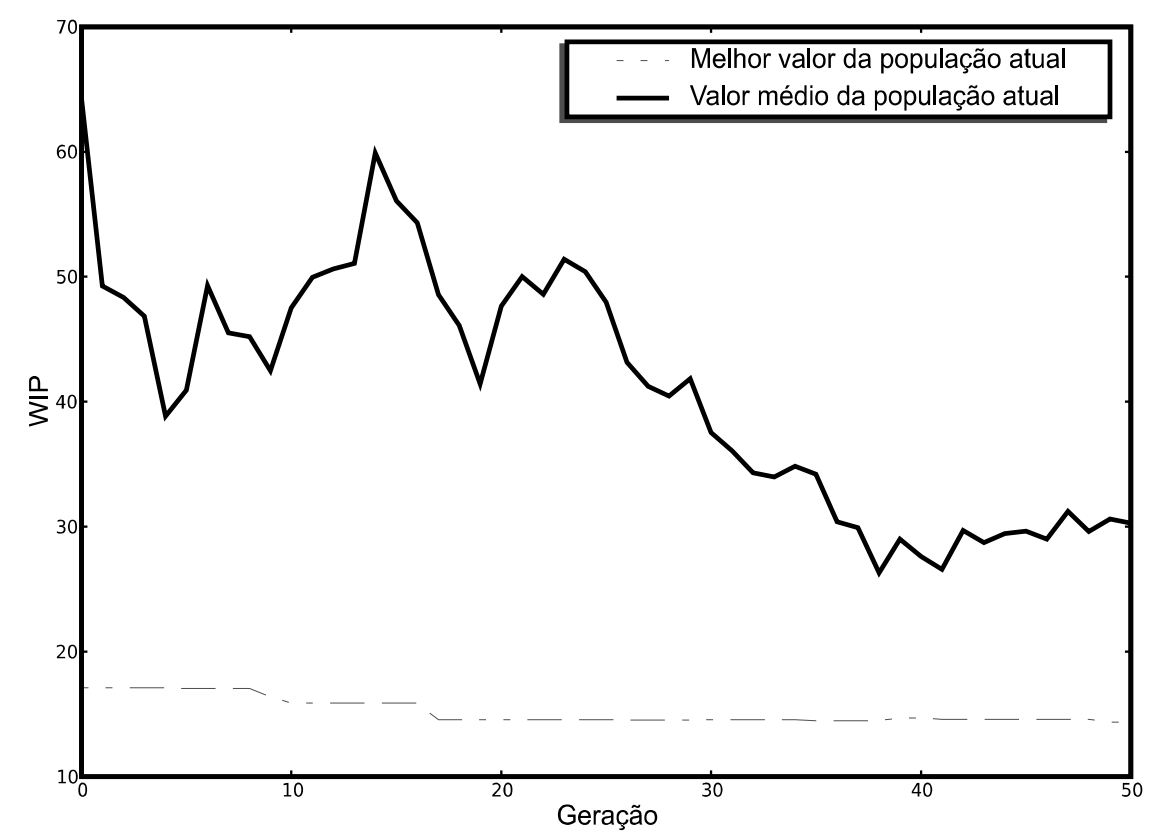

Gráfico 12. Evolução do inventário em processo ao longo das gerações 


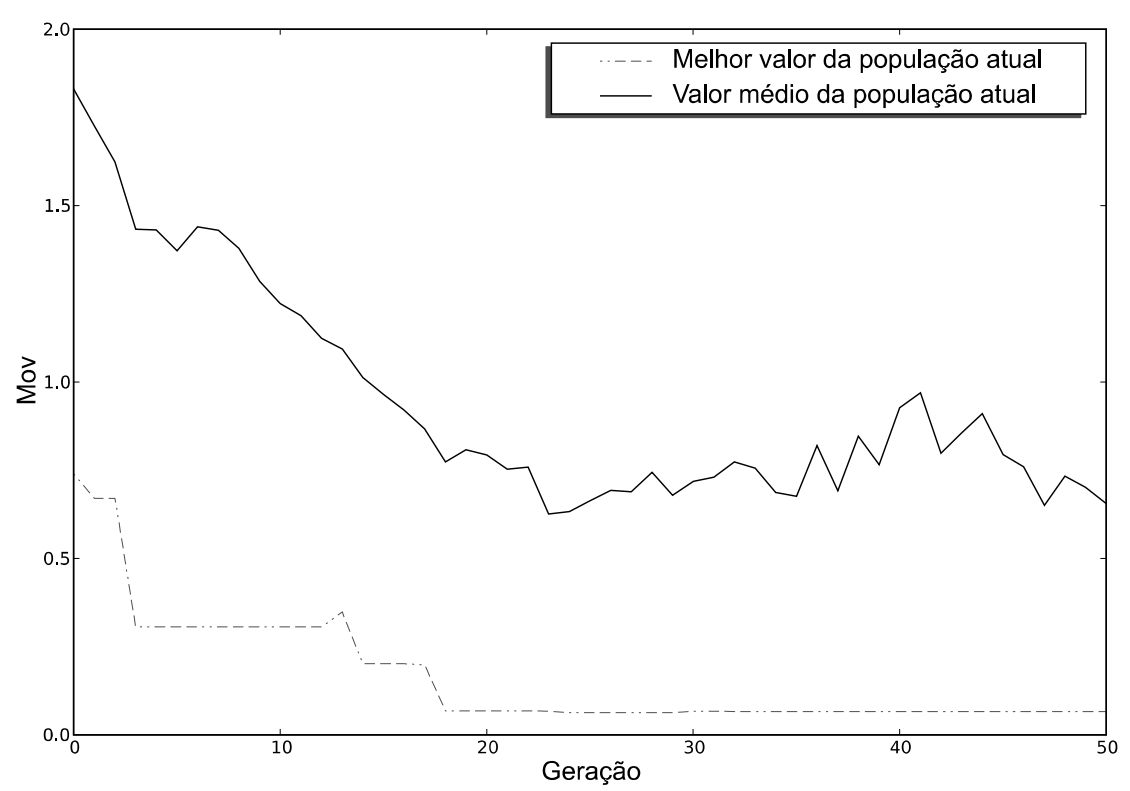

Gráfico 13. Evolução da movimentação intercelular ao longo das gerações

O Gráfico 15 exibe o caminho de redução simultânea das três funçõesobjetivo no espaço tridimensional.

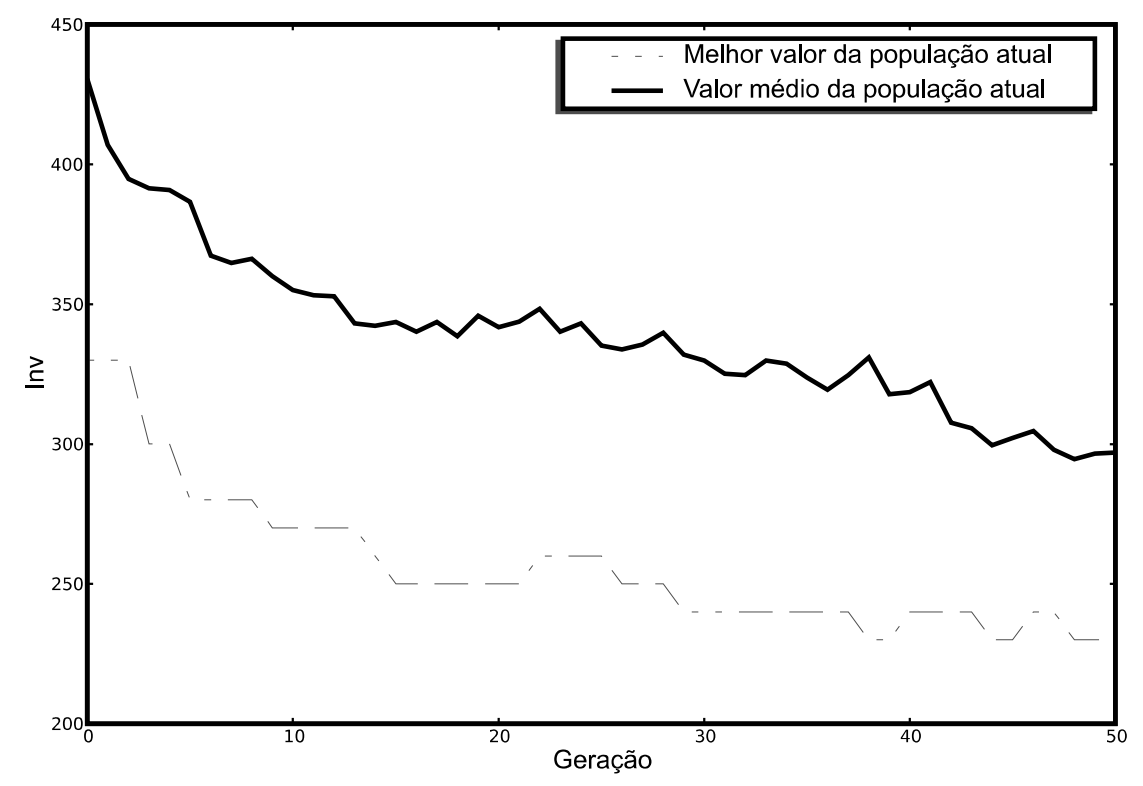

Gráfico 14. Evolução do investimento em máquinas ao longo das gerações 


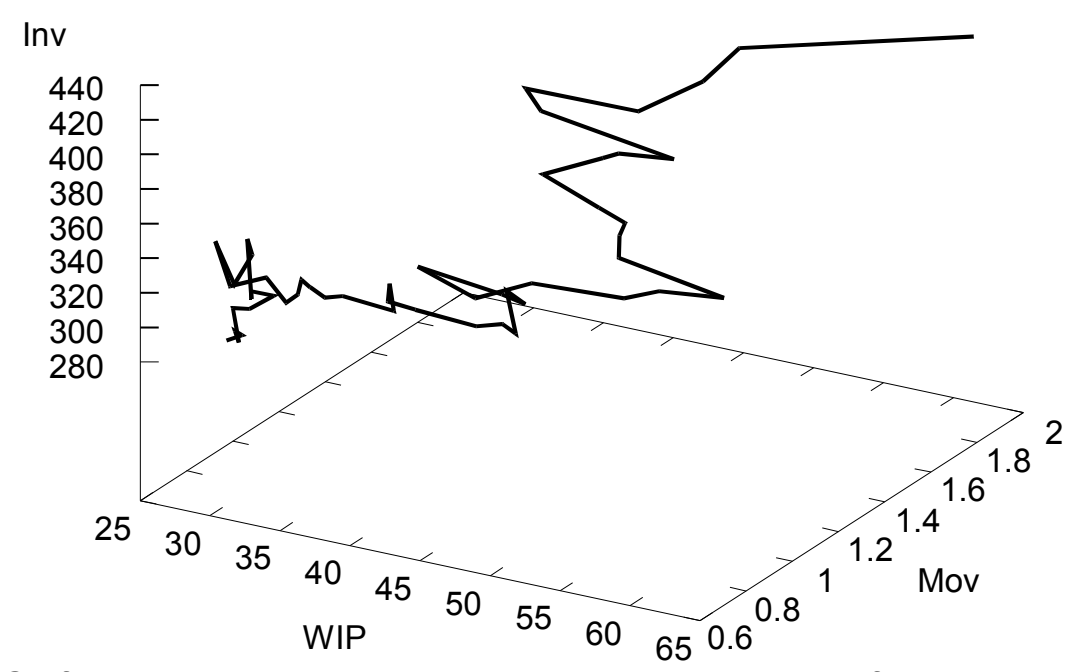

Gráfico 15. Evolução do valor médio populacional das 3 funções-objetivo em direção a menores valores do problema 2

O Gráfico 16 apresenta a população inicial, e a população final, a qual é uma aproximação do conjunto ótimo de Pareto. Verifica-se que o algoritmo movimentou as soluções na direção de valores mais baixos, mas a distância em relação à população inicial não foi tão grande quanto no problema 1.

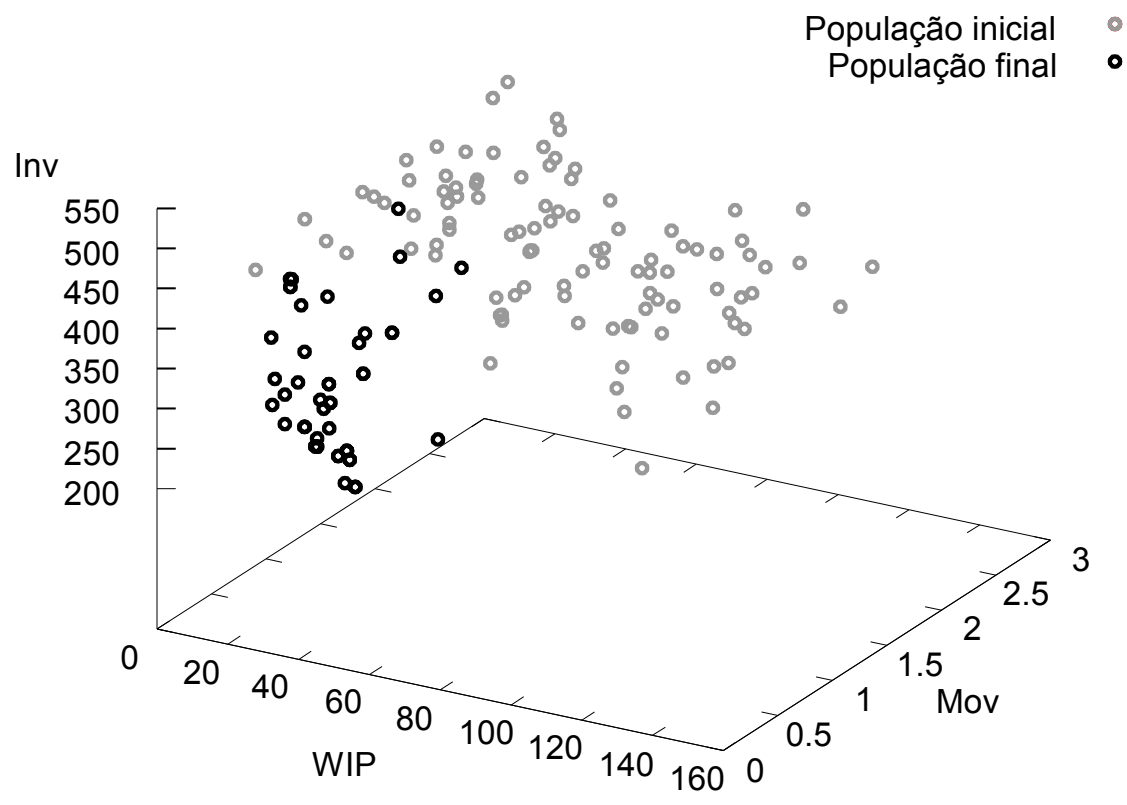

Gráfico 16. População inicial e aproximação da fronteira de Pareto no problema 2 
Aplicou-se o ALC aos 50 vetores objetivos obtidos, formando-se cinco clusters. Selecionaram-se as cinco soluções mais próximas de cada um dos centróides dos cinco clusters formados. A Tabela 28 exibe os vetores objetivos das cinco soluções obtidas.

Observa-se que as cinco soluções são de fato não-dominadas, pois nenhuma delas é melhor que qualquer outra nos três objetivos, e os melhores valores estão sombreados. Observa-se que a solução 5 tem o menor inventário médio em processo, a solução 2 tem a menor movimentação intercelular média e o menor investimento em máquinas. As soluções 1, 3 e 4 apresentam valores intermediários, e podem ser consideradas boas soluções de compromisso entre os três objetivos.

Tabela 28. Soluções não-dominadas obtidas pela redução da fronteira de Pareto aproximada. Os campos sombreados representam o melhor valor do respectivo objetivo

\begin{tabular}{|c|c|c|c|c|}
\hline Solução & $\begin{array}{l}\text { Inventário médio } \\
\text { em processo (WIP) }\end{array}$ & $\begin{array}{l}\text { Movimentação } \\
\text { intercelular média } \\
\text { (Mov) }\end{array}$ & $\begin{array}{l}\text { Investimento } \\
\text { máquinas (Inv) }\end{array}$ & em \\
\hline 1 & 15,08 & 1,0758 & 360 & \\
\hline 2 & 44,45 & 0,3273 & 250 & \\
\hline 3 & 29,09 & 0,5568 & 290 & \\
\hline 4 & 17,80 & 0,7774 & 320 & \\
\hline 5 & 15,02 & 0,7515 & 410 & \\
\hline
\end{tabular}

O Gráfico 17 exibe as cinco soluções no espaço-objetivo obtidas após a clusterização. Pode-se observar que as soluções selecionadas são uma amostra razoável da população final. As Figuras 42 a 46 contêm representações esquemáticas das soluções não-dominadas clusterizadas. Dispondo-se dessas soluções, pode-se aplicar um critério de preferência para escolher a solução mais adequada. 


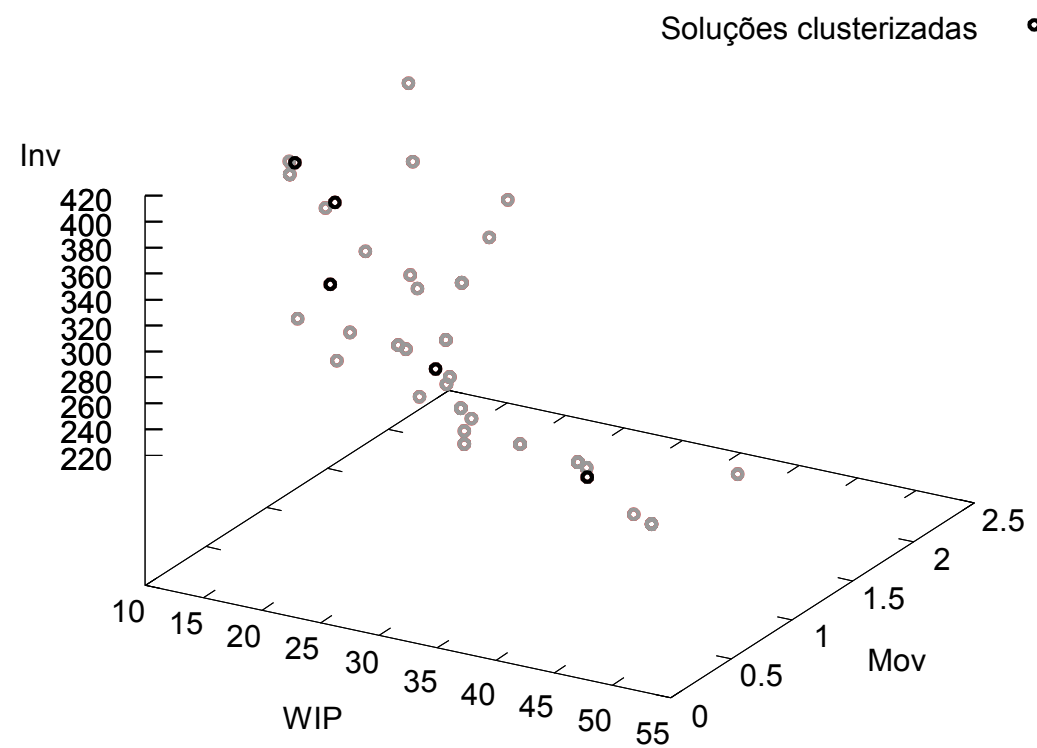

Gráfico 17. As soluções do problema 2 obtidas após a clusterização por ALC estão realçadas em preto

Célula 1

\begin{tabular}{|l|l|l|l|l|l|}
\hline 3.1 & 7.1 & & 10.1 & 11.1 & 12.1 \\
\hline 3.2 & 7.2 & 10.2 & 11.2 & 12.2 \\
\hline
\end{tabular}

Célula 2

\begin{tabular}{|l|l|l|l|l|l|l|l|l|l|}
\hline 1.1 & 2.1 & 4.1 & 5.1 & & 7.1 & 13.1 & 14.1 & 15.1 \\
\hline 2.2 & 4.2 & 5.2 & 7.2 & 13.2 & 14.2 & 15.2 \\
\hline
\end{tabular}

Célula 3

\begin{tabular}{|l|l|l|l|l|l|l|}
\hline 4.1 & 5.1 & 6.1 & 7.1 & 8.1 & 9.1 \\
\hline & 6.2 & 7.2 & 8.2 & 9.2 \\
\hline & & & \\
\hline & & & \\
\hline
\end{tabular}

WIP $=15.08$

Mov $=1.076$

Inv $=360$

Figura 42. Solução não-dominada 1 para o problema-teste

2 
Célula 1

\begin{tabular}{|l|l|l|l|l|l|l|l|l|l|l|l|l|l|l|l|l|l|l|l|l|l|l|}
\hline 4.1 & 5.1 & 6.1 & 8.1 & & 9.1 & 11.1 & 12.1 & 13.1 & 14.1 & 15.1 \\
\hline 6.2 & & 9.2 & 11.2 & 12.2 & & \\
\hline
\end{tabular}

Célula 2

\begin{tabular}{|l|l|l|l|l|l|l|l|l|}
\hline 1.1 & 2.1 & 3.1 & & & \\
\hline
\end{tabular}

Célula 3

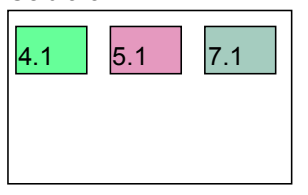

WIP $=44.45$

Mov $=0.3273$

Inv $=250$

Figura 43. Solução não-dominada 2 para o problema-teste 2

Célula 1

\begin{tabular}{|l|l|l|l|l|l|l|l|l|l|}
\hline 3.1 & 6.1 & 8.1 & 9.1 & 10.1 & 11.1 & 12.1 & 13.1 & 14.1 & 15.1 \\
\hline & 6.2 & & 9.2 & & & & & & \\
\hline
\end{tabular}

Célula 2

\begin{tabular}{|l|l|l|l|l|l|l|l|l|l|}
\hline 1.1 & 2.1 & 3.1 & 6.1 & 7.1 & 8.1 & 9.1 & 10.1 & 11.1 & 12.1 \\
\hline 2.2 & & & 7.2 & & & & & \\
\hline
\end{tabular}

Célula 3

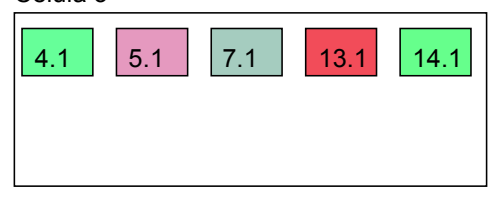

WIP $=29.09$

Mov $=0.5568$

Inv $=290$

Figura 44. Solução não-dominada 3 para o problema-teste 2 
Célula 1

\begin{tabular}{|c|c|c|c|c|c|c|c|}
\hline 1.1 & 2.1 & 3.1 & 7.1 & 10.1 & 11.1 & 12.1 & 15.1 \\
\hline 1.2 & 2.2 & 3.2 & 7.2 & 10.2 & 11.2 & 12.2 & 15.2 \\
\hline
\end{tabular}

Célula 2

\begin{tabular}{|l|l|l|}
\hline 7.1 & 13.1 & 14.1 \\
\hline 7.2 & 13.2 & 14.2 \\
\hline
\end{tabular}

Célula 3

\begin{tabular}{|l|l|l|l|l|l|}
\hline 4.1 & 5.1 & 6.1 & 7.1 & 8.1 & 9.1 \\
\hline & 6.2 & & 8.2 & 9.2 \\
\hline
\end{tabular}

WIP $=17.78$

Mov $=0.7774$

Inv $=320$

Figura 45. Solução não-dominada 4 para o problema-teste 2

Célula 1

\begin{tabular}{|l|l|l|l|l|l|l|l|}
\hline 1.1 & 2.1 & 3.1 & 7.1 & 10.1 & 11.1 & \begin{tabular}{|l|l|}
\hline 12.1 \\
\hline 2.2
\end{tabular} \\
\hline 3.2 & 7.2 & & 10.2 & 11.2 & 12.2 \\
\hline 2.3 & & & \\
\hline
\end{tabular}

Célula 2

\begin{tabular}{|l|l|l|l|l|l|l|l|l|}
\hline 4.1 & 5.1 & 7.1 & 12.1 & 13.1 & 14.1 & 15.1 \\
\hline 4.2 & 5.2 & 7.2 & & 13.2 & 14.2 & 15.2 \\
\hline & & & \\
\hline & 7.3 & & & \\
\hline
\end{tabular}

Célula 3

\begin{tabular}{|c|c|c|c|c|c|c|}
\hline 1.1 & 4.1 & 5.1 & 6.1 & 7.1 & 8.1 & 9.1 \\
\hline & & & 6.2 & 7.2 & 8.2 & 9.2 \\
\hline & & & & 7.3 & & \\
\hline
\end{tabular}

WIP $=15.02$

Mov $=0.7516$

Inv $=410$

Figura 46. Solução não-dominada 5 para o problema-teste 2 
Simulação da solução obtida por Venugopal (1992)

A solução obtida por Venugopal é indicada na Tabela 29, e foi simulada para se obter os valores das funções-objetivo consideradas neste trabalho.

Tabela 29 - Solução obtida por Venugopal (1992)

\begin{tabular}{cccccccccccccccc}
\hline \multirow{2}{*}{ Célula } & \multicolumn{11}{c}{ Tipo de máquina } \\
\cline { 2 - 5 } & 1 & 2 & 3 & 4 & 5 & 6 & 7 & 8 & 9 & 10 & 11 & 12 & 13 & 14 & 15 \\
\hline 1 & 1 & 1 & 1 & 0 & 0 & 0 & 1 & 0 & 0 & 1 & 0 & 0 & 0 & 0 & 0 \\
2 & 0 & 0 & 0 & 1 & 1 & 1 & 0 & 1 & 2 & 0 & 0 & 0 & 0 & 0 & 0 \\
3 & 0 & 0 & 0 & 0 & 0 & 0 & 0 & 0 & 0 & 0 & 1 & 2 & 1 & 1 & 1 \\
\hline
\end{tabular}

A representação gráfica da solução obtida por Wu é exibida na Figura 47.

Célula 1

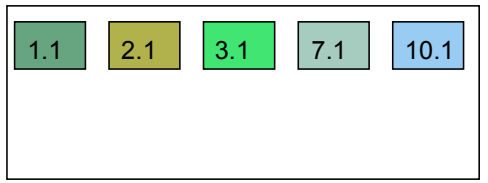

Célula 2

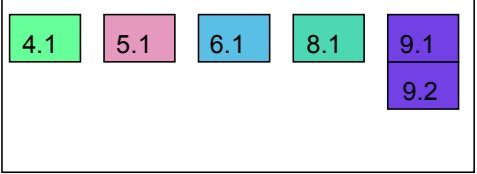

Célula 3

\begin{tabular}{l|l|l|l|l|}
\hline 11.1 & 12.1 & 13.1 & 14.1 & 15.1 \\
\hline 12.2 & \\
WIP $=117,90$ \\
Mov $=0,2655$ \\
Inv $=170$
\end{tabular}

Figura 47. Representação gráfica da solução obtida por Venugopal (1992)

Simulou-se a solução obtida por Venugopal para se obter os valores de 
inventário em processo (WIP), movimentação intercelular (Mov) e número total de máquinas (Inv). Lembrando-se que a solução do referido autor não considera réplicas de máquinas, apenas os tipos. Em outras palavras, todas as réplicas de um mesmo tipo encontram-se na mesma célula. Os parâmetros utilizados na simulação estão exibidos na Tabela 30.

Tabela 30 - Valores adotados para os parâmetros da simulação da solução obtida por Venugopal(1992)

\begin{tabular}{cc}
\hline Parâmetro & Valor adotado \\
\hline Tempo de simulação & 9600 minutos \\
Tempo de aquecimento & 2400 minutos \\
Número de replicações & 30 \\
\hline
\end{tabular}

Os resultados obtidos estão exibidos naTabela 31.

Tabela 31 - Resultados da simulação da solução obtida por Venugopal (1992)

\begin{tabular}{lccc}
\hline \multicolumn{1}{c}{ Função objetivo } & Média & Desvio-padrão & $\begin{array}{c}\text { Intervalo de } \\
\text { confiança 95\% }\end{array}$ \\
\hline $\begin{array}{l}\text { Inventário em } \\
\text { processo (lotes) }\end{array}$ & 117,90 & 28,95 & {$[107,54 ; 128,26]$} \\
$\begin{array}{l}\text { Movimentação } \\
\text { intercelular por lote }\end{array}$ & 0,2655 & 0,006722 & {$[0,2631 ; 0,2679]$} \\
Investimento total & 170 & 0 & 0 \\
\hline
\end{tabular}

Comparando-se os resultados da Tabela 31 com as soluções nãodominadas obtidas (Tabela 28), constata-se que a solução de Venugopal apresenta maior inventário em processo, mas a movimentação intercelular e investimento total são consideravelmente menores. No entanto, como os Gráficos 12, 13 e 14 indicam que o algoritmo não convergiu completamente, espera-se obter melhores soluções não-dominadas com a execução do procedimento por maior tempo. 


\subsection{Considerações finais}

Neste trabalho, foram apresentados os resultados da aplicação do modelo proposto a dois conjuntos de dados da literatura. Exibiram-se os gráficos das reduções dos valores de inventário em processo (WIP), movimentação intercelular (Mov) e investimento em máquina (Inv).

Também apresentaram-se graficamente a população inicial e a população final (a qual é uma aproximação da fronteira de Pareto). As soluções após a clusterização foram representadas esquematicamente juntamente com os valores de seus vetores objetivos.

Especificamente no problema-teste 1, foi possível observar resultados promissores ao comparar as soluções não-dominadas obtidas com a solução da literatura. Tomando-se, por exemplo, a solução não-dominada 5, obteve-se uma redução de $66,37 \%$ na movimentação intercelular, a um investimento $38,80 \%$ maior, ressaltando o trade-off entre essas duas medidas. As outras soluções nãodominadas representam trade-offs diferentes entre as três funções-objetivo consideradas.

No próximo capítulo apresentam-se as conclusões e sugerem-se linhas de pesquisa para o prosseguimento do presente trabalho. 


\section{CONSIDERAÇÕES FINAIS E TRABALHOS FUTUROS}

Este trabalho teve o objetivo geral de propor um procedimento híbrido multiobjetivo para a formação de células de manufatura com o uso de otimização baseada em simulação. Foi feita uma revisão teórica dos conceitos, técnicas e métodos pertinentes ao trabalho; apresentou-se detalhadamente o procedimento proposto; e por fim aplicou-se o procedimento a dois problemas-teste extraídos da literatura.

Apresentou-se a formulação matemática do modelo de otimização multiobjetivo para a solução do problema de formação de células de manufatura, considerando a minimização de três funções-objetivo: inventário em processo, movimentação intercelular e investimento em máquinas.

Desenvolveu-se um modelo de simulação de eventos discretos para representar o sistema de manufatura celular. Os resultados de simulações para a verificação e validação do modelo foram comparados com estimativas teóricas, assegurando sua validade sob as hipóteses previamente estabelecidas quanto ao comportamento dinâmico do sistema.

O algoritmo genético desenvolvido demonstrou ser capaz de explorar o espaço de soluções factíveis na direção da melhoria simultânea das três funçoesobjetivo consideradas.

Implementou-se uma aplicação híbrida para a integração do modelo de simulação ao algoritmo genético, utilizando as linguagens de programação $\mathrm{C}++\mathrm{e}$ Python. O algoritmo genético, escrito em $\mathrm{C++}$, dispara o simulador, escrito em Python, quando precisa atribuir o valor de fitness a uma solução.

Nas duas instâncias de problemas submetidas ao modelo, foi possível 
gerar um conjunto sintético de configurações não-dominadas para as células de manufatura, as quais apresentaram trade-offs entre as funções-objetivo investigadas. Um procedimento baseado em análise de agrupamentos hierárquica foi empregado para a redução da população final. Além disso, apresentaram-se visualmente as células de manufatura obtidas juntamente com suas medidas de desempenho, permitindo a comparação direta entre soluções, e facilitando a escolha da melhor alternativa.

Também foi possível observar algumas interações particulares entre as funções-objetivo ao longo do processo de busca executado pelo algoritmo genético, evidenciando o caráter multiobjetivo do problema.

No problema-teste 1 , as células formadas mostraram-se não-dominadas em relação à solução proposta na literatura. Logo, são configurações equivalentes, representando trade-offs entre as funções-objetivo consideradas. Dependendo das particularidades da empresa que pretende implantar a manufatura celular, pode ser mais vantajoso, por exemplo, uma configuração celular que exija maior número de máquinas, mas que possua inventários e movimentação mais baixos.

Por fim, os resultados indicaram que é possível obter configurações eficientes de células de manufatura explorando ganhos simultâneos em mais de uma medida de desempenho ao se otimizar o inventário em processo, a movimentação intercelular e o número total de máquinas. Isso representa uma vantagem em relação a abordagens uniobjetivo, que são capazes de otimizar apenas um aspecto de um sistema celular, não considerando o impacto em outros fatores relevantes. 
Trabalhos futuros

Para a extensão do presente trabalho, sugerem-se as seguintes direções de pesquisa:

- Executar o algoritmo genético por mais tempo para a obtenção de melhores soluções;

- Usar programação paralela para explorar maior capacidade computacional;

- Implementar a simulação em $\mathrm{C}++$, linguagem mais favorável a cálculos matemáticos que Python;

- Empacotar o software em uma aplicação amigável ao usuário;

- Usar uma função de dominância baseada em teste de hipótese;

- Incorporar outros fatores no modelo, como a área das máquinas, o sistema de movimentação, e operadores. 



\section{REFERÊNCIAS}

ADIL, G.; RAJAMANI, D.; STRONG, D. (1996). Cell formation considering alternate routeings. International Journal of Production Research, v.34, p.1361-1380.

AHN, C.W. (2006). Advances in evolutionary algorithms: theory, design and practice. Springer.

ASKIN, R.; CIARALLO, F.; LUNDGREN, N. (1999). Empirical evaluation of holonic and fractal layouts. International Journal of Production Research, v.37, n. 5, p.961-978.

ASKIN, R.G.; GOLDBERG, J.B. (2001). Design and analysis of lean production systems. Wiley.

AZADIVAR, F.; TOMPKINS, G. (1999). Simulation optimization with qualitative variables and structural model changes: A genetic algorithm approach. European Journal of Operational Research, v.113, p.169-182.

AZADIVAR, F.; WANG, J. (2000). Facility layout optimization using simulation and genetic algorithms. International Journal of Production Research, v.38, p.4369-4383.

BÄCK, T.; HAMMEL, U.; SCHWEFEL, H. (1997). Evolutionary computation: comments on the history and current state. IEEE Transactions on Evolutionary Computation, v.1, n.1, p.3-17.

BAHOUTH, A. et al. (2007). Revisiting the issue of performance enhancement of discrete event simulation software. In: 40TH ANNUAL SIMULATION SYMPOSIUM, ANSS, 2007. Proceedings of the 40th Annual Simulation Symposium, p.114-122.

BENJAAFAR, S.; HERAGU, S.S.; IRANI, S.A. (2002). Next generation factory layouts: research challenges and recent progress. Interfaces, v.32, n.6, p.58-76.

BUZACOTT, J.A.; SHANTHIKUMAR, J.G. (1992). Stochastic models of manufacturing systems. Prentice Hall.

CHINCHULUUN, A.; PARDALOS, P.M. (2007). A survey of recent developments in multiobjective optimization. Annals of Operations Research, v.154, p.29-50.

CHU, C.; TSAI, M. (1990). Comparison of three array-based clustering techniques for manufacturing cell formation. International Journal of Production Research, v.28, p.1417-1433.

COELLO, C.A.C. (2006). Evolutionary multi-objective optimization: a historical view of the field. Computational Intelligence Magazine, v.1, n.1, p.28-36. 
COELLO, C.A.C.; LAMONT, G.B.; VELDHUIZEN, D.A.V. (2007). Evolutionary algorithms for solving multi-objective problems. Springer.

DE HOON, M.J.L; IMOTO, S.; MIYANO, S. (2007). The C clustering library. Disponível em:<http://bonsai.ims.u-tokyo.ac.jp/ mdehoon/software/cluster/cluster.pdf >. Acesso em: 21 jan.2008.

DEB, K. (2001). Multi-objective optimization using evolutionary algorithms. Wiley.

DEB, K. et al. (2002). A fast and elitist multiobjective genetic algorithm: NSGA-II. IEEE Transactions on Evolutionary Computation, v.6, n.2, p.182-197.

DIMOPOULOS, C. (2007). Explicit consideration of multiple objectives in cellular manufacturing. Engineering Optimization, v.39, n.5, p.551-565.

EHRGOTT, M. (1999). Multicriteria optimization. Springer.

FRALEY, C.; RAFTERY, A.E. (1998). How many clusters? Which clustering method? Answers via model-based cluster analysis. Computer Journal, v.41, p.578-588.

FU, M.C. (2002). Optimization for simulation: theory vs. practice. INFORMS Journal on Computing, v.14, p.192-215.

FU, M.C.; GLOVER, F.W.; APRIL, J. (2005). Simulation optimization: a review, new developments, and applications. In: WINTER SIMULATION CONFERENCE, 2005. Proceedings of the 2005 Winter Simulation Conference, p.83-95.

GAREY, M.R.; JOHNSON, D.S. (1979). Computers and intractability: a guide to the theory of np-completeness. W. H. Freeman.

GENDREAU, M.; POTVIN, J.Y. (2005). Metaheuristics in combinatorial optimization. Annals of Operations Research, v.140, p.189-213.

GOLDBERG, D.E. (1989). Genetic algorithms in search, optimization, and machine learning. Addison-Wesley Professional.

GONÇALVES FILHO, E.V.; TIBERTI, A.J. (2006). A group genetic algorithm for the machine cell formation problem. International Journal of Production Economics, v.102, n.1, p.1-21.

GUPTA, Y.; GUPTA, M.; KUMAR, A.; SUNDARAM, C. (1996). Genetic algorithmbased approach to cell composition and layout design problems. International Journal of Production Research, v.34, n.2, p.447-482.

HALLAM, N.; BLANCHFIELD, P.; KENDALL, G. (2005). Handling diversity in Evolutionary Multiobjective Optimisation. In: IEEE CONGRESS ON EVOLUTIONARY COMPUTATION, 3., 2005. Proceedings of the 2005 IEEE Congress on Evolutionary Computation, p.2233-2240. 
HOPP, W.; SPEARMAN, M. (2000). Factory physics. 2.ed. McGraw-Hill//rwin.

HURLEY, S.F.; WHYBARK, D.C. (1999). Inventory and capacity trade-offs in a manufacturing cell. International Journal of Production Economics, v.59, p.203-212.

IRANI, S.A. (Ed.). (1999). Handbook of cellular manufacturing systems. WileyInterscience.

JAYASWAL, S.; ADIL, G.K. (2004). Efficient algorithm for cell formation with sequence data, machine replications and alternative process routings. International Journal of Production Research, v.42, n.12, p.2419-2433.

JOINES, J.A.; ROBERTS, S.D. (1999). Simulation in an object-oriented world. In: WINTER SIMULATION CONFERENCE, 1999. Proceedings of the 1999 Winter Simulation Conference, p.132-140.

KHER, H.V.; JENSEN, J.B. (2002). Shop performance implications of using cells, partial cells, and remainder cells. Decision Sciences, v.33, n.2, p.161-190.

KING, J.R. (1980). Machine-component grouping in production flow analysis: an approach using a rank order clustering algorithm. International Journal of Production Research, v.18, p.213-232.

LAW, A.; KELTON, W.D. (1999). Simulation modeling and analysis. 3.ed. McGrawHill.

LIKER, J. (2003). O modelo Toyota. McGraw-Hill.

MANSOURI, S.A.; MOATTAR, S.M.; NEWMAN, S.T. (2000). A review of the modern approaches to multi-criteria cell design. International Journal of Production Research, v.38, n.5, p.1201-1218.

MAVRIDOU, T.; PARDALOS, P. (1997). Simulated annealing and genetic algorithms for the facility layout problem: a survey. Computational Optimization and Applications, v.7, n.1, p.111-126.

MICHALEWICZ, Z. (1998). Genetic algorithms + data structures = evolution programs. Springer.

MITCHELL, T. (1997). Machine learning. McGraw-Hill Education.

MONTREUIL, B.; VENKATADRI, U.; RARDIN, R. (1999). Fractal layout organization for job shop environments. International Journal of Production Research, v.37, n.3, p.501-521.

NOMDEN, G.; SLOMP, J.; SURESH, N.C. (2006). Virtual manufacturing cells: A taxonomy of past research and identification of future research issues. International Journal of Flexible Manufacturing Systems, v.17, n.2, p.71-92. 
PAPADIMITRIOU, C.H.; STEIGLITZ, K. (1998). Combinatorial optimization: algorithms and complexity. (Unabridged). Dover Publications.

PAPOULIS, A.; PILLAI, S.U. (2001). Probability, random variables and stochastic processes. 4.ed. McGraw-Hill Science/Engineering/Math.

PATTERSON, J.W.; FREDENDALL, L.D.; CRAIGHEAD, C.W. (2002). The impact of non-bottleneck variation in a manufacturing cell. Production Planning \& Control, v.13, p.76-85.

PIERREVAL, H.; PARIS, J.L. (2003). From 'simulation optimization' to 'simulation configuration' of systems. Simulation Modelling Practice and Theory, v.11, n.1, p.5-19.

PITOMBEIRA NETO, A.R.; GONÇALVES FILHO, E.V. (2007). Projeto de arranjos físicos distribuídos por meio de Otimização da Simulação e Algoritmos Genéticos. In: SIMPÓSIO BRASILEIRO DE PESQUISA OPERACIONAL, 39, 2007. Anais do XXXIX Simpósio Brasileiro de Pesquisa Operacional, Fortaleza.

PYTHON programming language. Disponível em: <http://www.python.org>. Acesso em: 26 nov.2007.

RAO, H.; PHAM, S.; GU, P. (1999). Genetic algorithms-based approach for design of manufacturing systems: an industrial application. International Journal of Production Research, v.37, n.3, p.557-580.

SAAD, S.; LASSILA, A. (2004). Layout design in fractal organizations. International Journal of Production Research, v.42, n.17, p.3529-3550.

SARGENT, R.G. (2005). Verification and validation of simulation models. In: WINTER SIMULATION CONFERENCE, 2005. Proceedings of the 2005 Winter Simulation Conference, p.130-143.

SEIFODDINI, H.K. (1989). Single linkage versus average linkage clustering in machine cells formation applications. Computers \& Industrial Engineering, v.16, p.419-426.

SINGH, N.; RAJAMANI, D. (1996). Cellular manufacturing systems: design, planning and control. Springer.

SLACK, N.; CHAMBERS, S.; JOHNSTON, R. (2002). Administração da produção. 2.ed. Atlas.

SURESH, N.C.; SLOMP, J. (2005). Performance comparison of virtual cellular manufacturing with functional and cellular layouts in DRC settings. International Journal of Production Research, v.43, n.5, p.945-979.

SOLIMANPUR, M.; VRAT, P.; SHANKAR, R. (2004). A multi-objective genetic algorithm approach to the design of cellular manufacturing systems. International 
Journal of Production Research, v.42, v.7, p.1419-1441.

TATE, D.; SMITH, A. (1995). A genetic approach to the quadratic assignment problem. Computers \& Operations Research, v.22, n.1, p.73-83.

TAM, K. (1992). Genetic algorithms, function optimization, and facility layout design. European Journal of Operational Research, v.63, n.2, p.322-346.

VAKHARIA, A.J.; ASKIN, R.G.; SELIRN, H.M. (1999) Flexibility considerations in cell design. IRANI, S.A. (ed.). Handbook of cellular manufacturing. Nova lorque: John Wiley and Sons.

VENKATADRI, U.; RARDIN, R.L.; MONTREUIL, B. (1997). Design methodology for fractal layout organization. IIE Transactions, v.29, n.10, p.911-924.

VENUGOPAL, V.; NARENDRAN, T. (1992). A genetic algorithm approach to the machine-component grouping problem with multiple objectives. Computers \& Industrial Engineering, v.22, n.4, p.469-480.

WALL, M. (1996). GAlib: a C++ library of genetic algorithm components. Disponível em: <http://lancet.mit.edu/ga/dist/galibdoc.pdf>. Acesso em: 21 jan.2008.

WEMMERLOV, U.; JOHNSON, D.J. (1997). Cellular manufacturing at 46 user plants: Implementation experiences and performance improvements. International Journal of Production Research, v.35, v.1, p.29-49.

(2000). Empirical findings on manufacturing cell design. International Journal of Production Research, v.38, n.3, p.481-507.

WHITT, W. (1993). Approximations for the $\mathrm{Gl} / \mathrm{G} / \mathrm{m}$ queue. Production and Operations Management, v.2, n.2, p.114-61.

WU, N. (1998). A concurrent approach to cell formation and assignment of identical machines in group technology. International Journal of Production Research, v.36, n.8, p.2099-2114.

YENIAY, O. (2005). Penalty function methods for constrained optimization with genetic algorithms. Mathematical and Computational Applications, v.10, p.45-56.

YIN, Y.; YASUDA, K. (2006). Similarity coefficient methods applied to the cell formation problem: a taxonomy and review. International Journal of Production Economics, v.101, n.2, p.329-352.

ZITZLER, E.; THIELE, L. (1999). Multiobjective evolutionary algorithms: a comparative case study and the strength Pareto approach. IEEE Transactions on Evolutionary Computation, v.3, p.257-271. 



\section{APÊNDICE A - CÓDIGO-FONTE DO MODELO DE SIMULAÇÃO EM PYTHON}

Abaixo está listado o código-fonte em linguagem Python do modelo de simulação que é utilizado pelo algoritmo genético para avaliação das soluções. $O$ código importa o módulo SimPy de simulação de eventos discretos, o qual deve estar previamente instalado, e os módulos random e math, nativos da linguagem. Além disso, informações quanto às demandas dos produtos, tempos de processamento e seqüências de fabricação são lidos de arquivos de texto.

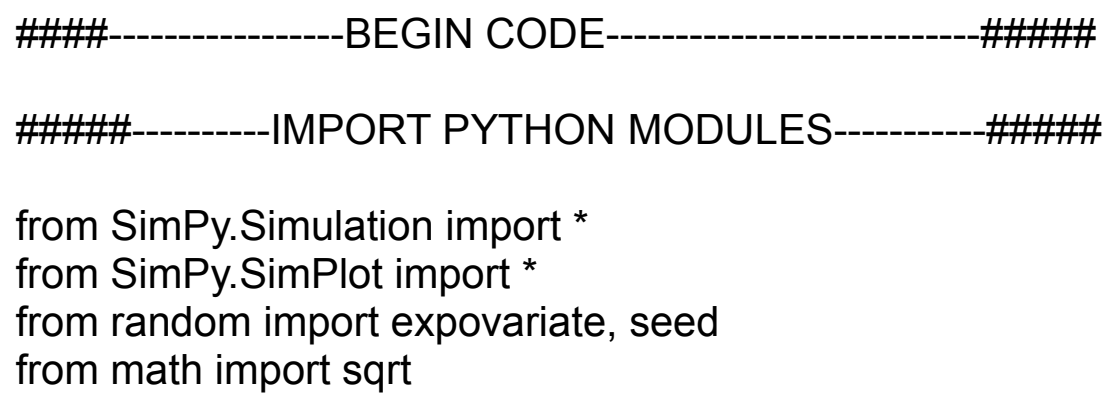

class Cell:

"'"'A generic cell"'"'

def__init_(self, name, machines, ide): 


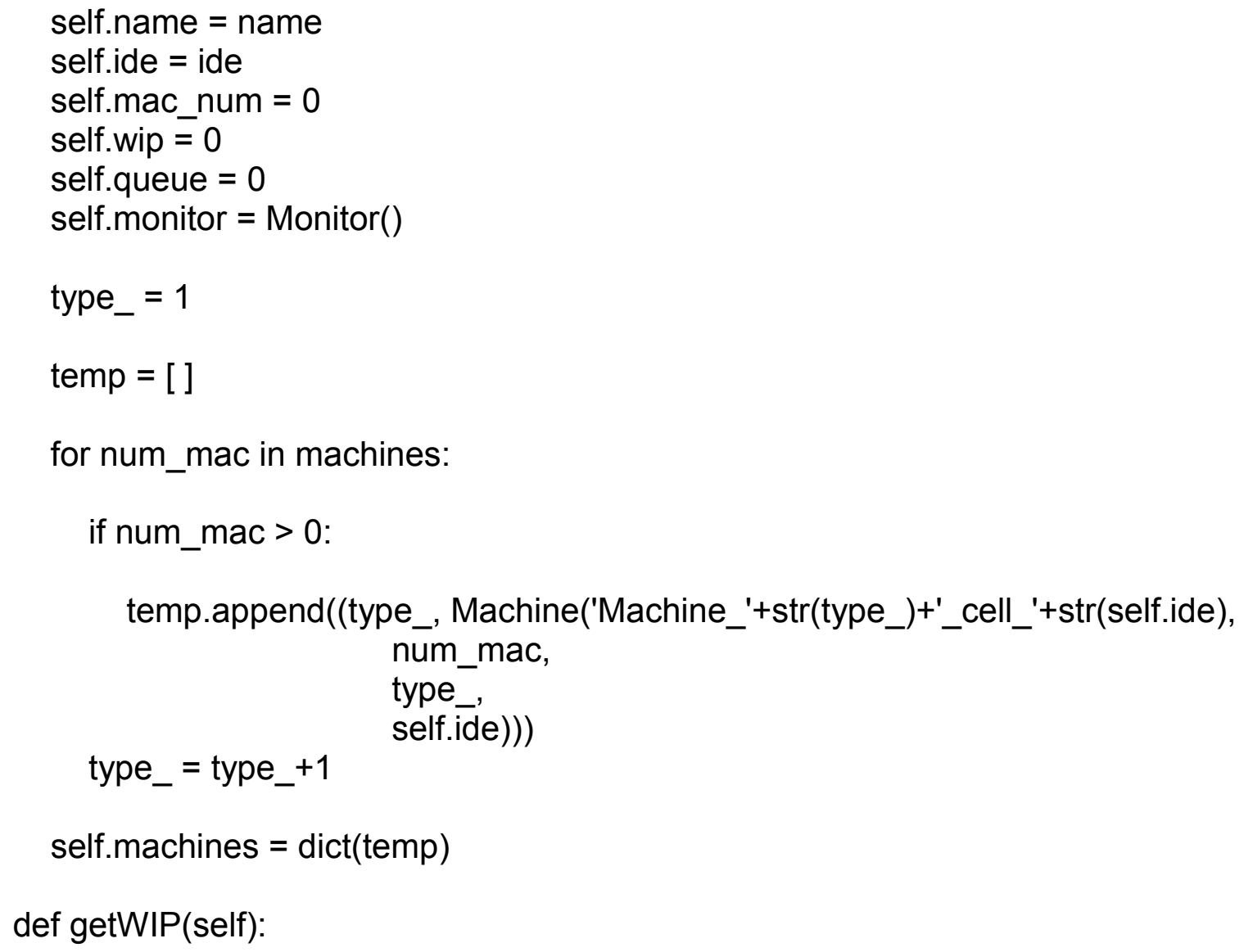


Process._init_(self, name=name)

self.product_type $=$ p_type

self.seq $=$ seq

self.times $=$ times

self.bat $=$ bat

self.stage $=0$

self.current_cell $=0$

self.inter_moves $=0$

def process(self, Cells):

global WIP, WIP_monitor, Lead_monitor, WIP_max, inter_moves, warm_flag

ITime $=$ now ()

WIP $=$ WIP+1

WIP_monitor.observe(WIP)

for machine_type in self.seq:

if self.current_cell $==0$ :

filtered $=[]$

for $\mathrm{i}$, cell in Cells.iteritems():

if cell.machines.has_key(machine_type):

filtered.append((cell.ide, cell))

filtered $=\operatorname{dict}($ filtered $)$

chosen_cell = filtered. popitem()

self.current_cell $=$ chosen_cell[1].ide

self.stage $+=1$ \#Advances stage

Cells[self.current_cell].getWIP()

Cells[self.current_cell].monitor.observe(Cells[self.current_cell].wip)

yield request, self, Cells[self.current_cell].machines[machine_type] yield hold, self, expovariate(1/self.times[machine_type-1])

yield release, self, Cells[self.current_cell].machines[machine_type]

Cells[self.current_cell].getWIP()

Cells[self.current_cell].monitor.observe(Cells[self.current_cell].wip) 
\#Current cell has required machine?

elif Cells[self.current_cell].machines.has_key(machine_type):

self.stage=self.stage +1 \#advances stage

Cells[self.current_cell].getWIP()

Cells[self.current_cell].monitor.observe(Cells[self.current_cell].wip)

yield request, self, Cells[self.current_cell].machines[machine_type] yield hold, self, expovariate(1/self.times[machine_type-1])

yield release, self, Cells[self.current_cell].machines[machine_type]

Cells[self.current_cell].getWIP()

Cells[self.current_cell].monitor.observe(Cells[self.current_cell].wip)

\#Current cell hasn't got required machine

else:

\#Chooses next cell

filtered $=[]$

for $\mathrm{i}$, cell in Cells.iteritems():

if cell.machines.has_key(machine_type):

filtered.append((cell.ide, cell))

filtered $=\operatorname{dict}($ filtered $)$

\#Identifies cell with least wip:

$k=1$

while not filtered.has_key(k): \#Tests till find a feasible key $\mathrm{k}+=1$

least_wip = filtered[k].getQueue( $)$ \#Pick a wip value

least_ide $=$ filtered $[\mathrm{k}]$.ide

for $i$, cell in filtered.iteritems():

if cell.getQueue $($ ) < least_wip: least_wip = cell.getQueue () least_ide $=$ cell.ide 
\#Enters new cell

self.current_cell $=$ least_ide

self.inter_moves $=$ self.inter_moves +1

self.stage=self.stage +1 \#advances stage

Cells[self.current_cell].getWIP()

Cells[self.current_cell].monitor.observe(Cells[self.current_cell].wip)

yield request, self, Cells[self.current_cell].machines[machine_type] yield hold, self, expovariate(1/self.times[machine_type-1])

yield release, self, Cells[self.current_cell].machines[machine_type]

Cells[self.current_cell].getWIP()

Cells[self.current_cell].monitor.observe(Cells[self.current_cell].wip)

if self.stage $==$ len(self.seq) -1 :

Cells[self.current_cell].getWIP()

Cells[self.current_cell].monitor.observe(Cells[self.current_cell].wip)

inter_moves.observe(self.inter_moves)

WIP $=$ WIP -1

WIP_monitor.observe(WIP)

FTime $=$ now ()$-I$ Time

Lead_monitor.observe(FTime)

if now ()$>$ warm_up and warm_flag $==0$ :

WIP_monitor.reset()

inter_moves.reset()

warm_flag $=1$

for key, cell in Cells.iteritems():

cell.monitor.reset()

if WIP > WIP max:

end_time $=$ now ()

stopSimulation()

class Demand(Process):

"'"'Generates an exponential demand arrival pattern"'"' 


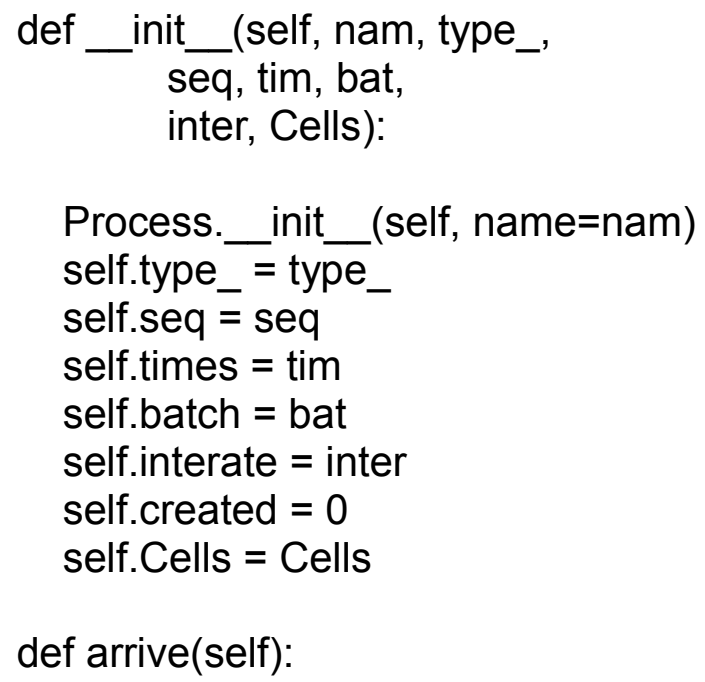

while 1:

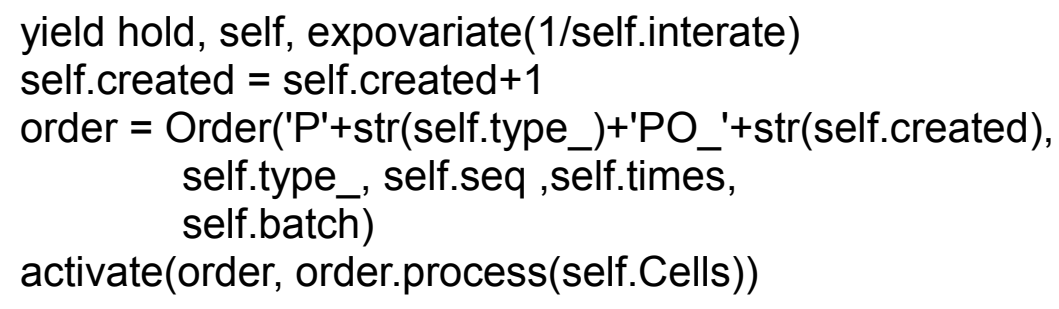

class Model:

def__init__self, cell_list, demands, seq, times, lot_size=1, avail=9600, name='A cellular system'):

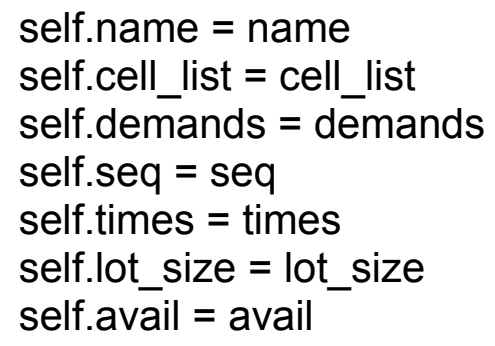

def buildModel(self, cell_list, demands, seq, times, lot_size, avail):

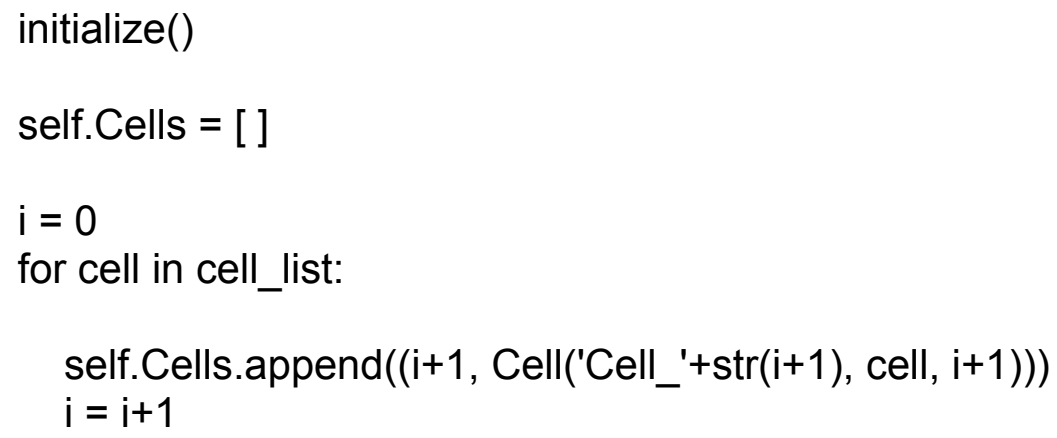


self.Cells $=\operatorname{dict}($ self.Cells)

\#Demand processes creation and activation

$\mathrm{i}=0$

for demand in demands:

$$
\begin{aligned}
& \text { demand_process }=\text { Demand("Demand_"+str(i+1), i+1, seq[i], } \\
& \text { times[i], lot_size, avail/demand, self.Cells) } \\
& \text { activate(demand_process, demand_process.arrive()) } \\
& i=i+1
\end{aligned}
$$

def simulation(self, sim_time, reps $=1$, SEED $=1$ ):

global WIP_monitor, WIP

global warm_flag, MeanWIP, MeanMoves

for $i$ in range( 1 , reps +1$)$ :

seed(SEED+i)

$\mathrm{WIP}=0$

warm_flag $=0$

self.buildModel(self.cell_list, self.demands, self.seq, self.times, self.lot_size, self.avail)

simulate(sim_time)

RepMeanWIP.observe(WIP_monitor.timeAverage())

RepMeanMoves.observe(inter_moves.mean()) 
lot_size $=1$

avail $=9600.0$

WIP_max $=500$

demands $=[$ ]

seq $=[]$

times $=[]$

\#Reading of external file

demands_file $=$ open('Demands.txt')

seq_file = open('Sequences.txt')

times_file $=$ open('Times.txt')

\#\#Product demands

num_prods $=0$

for line in demands_file:

for word in line.split():

demands.append(float(word))

num_prods $=$ num_prods +1

\#Production sequences

$i=0$

for line in seq_file:

seq.append([ ])

for word in line.split():

seq[i].append(int(word))

$\mathrm{i}=\mathrm{i}+1$

\#Production times

$i=0$

for line in times_file:

times.append([ ]) 
for word in line.split():

times[i].append(float(word))

$\mathrm{i}=\mathrm{i}+1$

\#Close files

demands_file.close()

seq_file.close ()

times_file.close()

\#\#\#\#

\#\#\#\#\#----------DECISION VARIABLE VALUES-----------\#\#\#\#

machines_ $1=[0,0,1,0,3,0,0,3,1,0,0,1,1]$

machines_2 $=[3,1,1,1,1,0,1,1,0,1,2,0,0]$

machines_3 $=[0,1,0,2,0,1,2,0,0,1,0,0,0]$

cell_list $=$ [machines_1, machines_2, machines_3]

\#\#\#\#\#----------END DECISION VARIABLE VALUES-----------\#\#\#\#

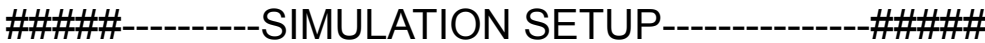

\#Statistical monitors (global)

inter_moves $=$ Monitor('Intercell_Moves')

WIP_monitor $=$ Monitor('WIP_monitor')

Lead_monitor $=$ Monitor('Lead time monitor')

RepMeanWIP = Monitor('Replications mean WIP')

RepMeanMoves $=$ Monitor('Replications mean moves')

\#Simulation parameters

sim_time $=12000$

warm_up $=0.2^{*}$ sim_time

reps $=5$ 
198

\#Global variables

WIP $=0$

warm_flag $=0$

\#\#Simulation Model Creation

Modelo $=$ Model(cell_list, demands, seq, times $)$

\#\#\#\#END SIMULATION SETUP \#\#\#\#

\#\#\#\#SIMULATION RUN \#\#\#\#

Modelo.simulation(sim_time, reps, 2)

\#\#\#\#END SIMULATION RUN \#\#\#\#

\#\#\#\#OUTPUT INFORMATION \#\#\#\#

MeanWIP = WIP_monitor.timeAverage ()

MeanMoves $=$ inter_moves.mean()

for $\mathrm{i}$ in range( 0 , reps):

print 'MeanWIP', i+1, '=', RepMeanWIP[i][1]

print 'InMean WIP over replications =', RepMeanWIP.mean()

print 'InStd deviation WIP over replications =', sqrt(RepMeanWIP.var()) \#Must correct bias

print ' $I n$ '

for $\mathrm{i}$ in range( 0 , reps):

print 'MeanMoves', i+1, '=', RepMeanMoves[i][1]

print 'InMean moves over replications =', RepMeanMoves.mean()

print 'InStd deviation moves over replications =', sqrt(RepMeanMoves.var()) \#Must correct bias

print 'MeanWIP:', MeanWIP 
print 'MeanMoves', MeanMoves

\#\#\#\#-END OUTPUT INFORMATION

\#\#\#\#

\#\#\#\#\#------------PLOT OF OUTPUT INFORMATION---------------\#\#\#\#

Plot $=$ SimPlot ()

Plot.plotStep(WIP_monitor, color='red', width=2, title='WIP')

Plot.mainloop()

\#\#\#\#-

PLOT OF OUTPUT INFORMATION

\#\#\#\#

\#\#\#\#-

END OF CODE

-\#\#\#\#\# 



\section{APÊNDICE B - RASTREAMENTO DA EXECUÇÃO DO MODELO DE SIMULAÇÃO}

O texto abaixo refere-se ao rastreamento da seqüência seguida por uma entidade durante a simulação. O objetivo é assegurar que a lógica do modelo de simulação está correta.

Na seqüência especificada abaixo, uma entidade-produto do tipo 5 chega no sistema de manufatura. A nomenclatura P5PO_94 indica que se trata de uma ordem de produção de número 94 para o produto P5.

Em seguida, são exibidas informações como número de operações (estágios), a seqüência de fabricação (seqüência de máquinas) e os tempos de processamento (em minutos).

No prosseguimento da fabricação do lote, é listada toda a seqüência de células e máquinas pelas quais a entidade passa, incluindo mudanças de células de produção, quando a célula na qual se encontra atualmente não possui a máquina necessária, e o teste feito pela entidade para escolher a próxima célula.

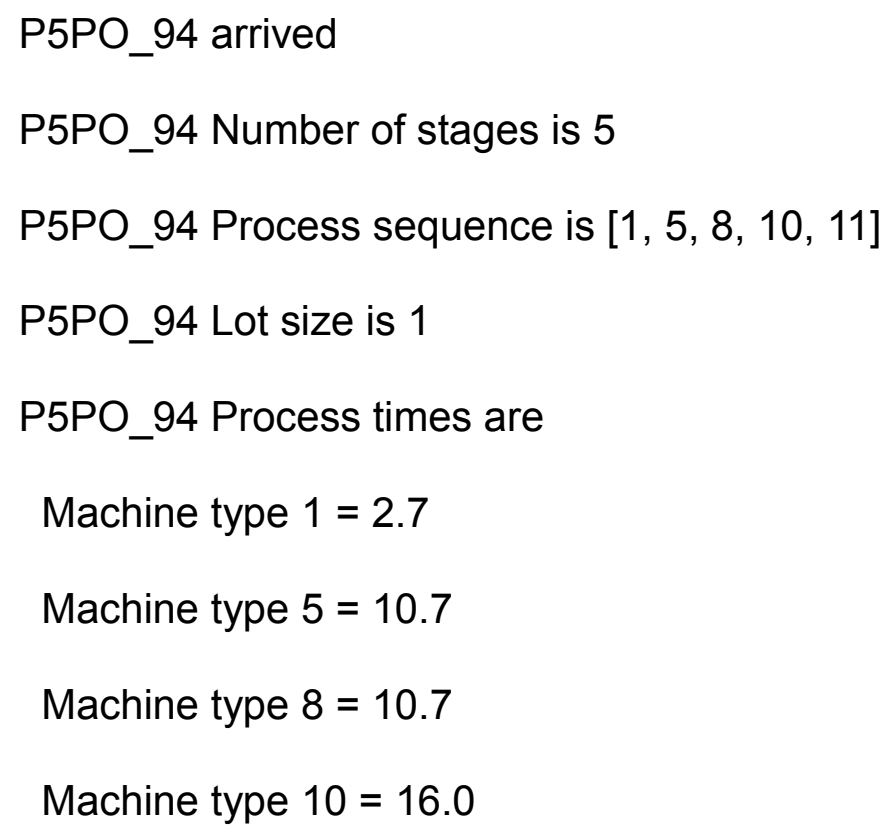


Machine type $11=10.7$

P5PO_94 entered cell 1

Cell 1 has machine types $[1,2,6,7]$

WIP of cell $1=12$

P5PO_94 enters stage 1

P5PO_94 will spend 10.578 time units in Machine_1_cell_1

P5PO_94 finished processing at Machine_1_cell_1

Cell_1 doesn't have machine type 5

Enter WIP in queue test

Cell 2 Queue $=5$

Cell 3 Queue $=0$

Least WIP in queue $=0$

Chosen cell $=3$

P5PO_94 entered cell 3

Cell 3 has machine types $[1,3,4,5,8,10,11]$

P5PO_94 enters stage 2

P5PO_94 will spend 4.360 time units in Machine_5_cell_3

P5PO_94 finished processing at Machine_5_cell_3

P5PO_94 remains in current cell: Cell_3

P5PO_94 enters stage 3

P5PO_94 will spend 0.365 time units in Machine_8_cell_3

P5PO_94 finished processing at Machine_8_cell_3

P5PO_94 remains in current cell: Cell_3

P5PO_94 enters stage 4

P5PO_94 will spend 10.089 time units in Machine_10_cell_3 
P5PO_94 finished processing at Machine_10_cell_3

P5PO_94 remains in current cell: Cell_3

P5PO_94 enters stage 5

P5PO_94 will spend 6.784 time units in Machine_11_cell_3

P5PO_94 finished processing at Machine_11_cell_3

P5PO_94 has finished processing 